University of Rhode Island

DigitalCommons@URI

Open Access Master's Theses

2013

\title{
Are Full-Length mRNA In Bos taurus Spermatozoa Transferred to the Oocyte During Fertilization?
}

Elizabeth Jane Anderson

University of Rhode Island, ejb887@gmail.com

Follow this and additional works at: https://digitalcommons.uri.edu/theses

\section{Recommended Citation}

Anderson, Elizabeth Jane, "Are Full-Length mRNA In Bos taurus Spermatozoa Transferred to the Oocyte During Fertilization?" (2013). Open Access Master's Theses. Paper 84.

https://digitalcommons.uri.edu/theses/84

This Thesis is brought to you for free and open access by DigitalCommons@URI. It has been accepted for inclusion in Open Access Master's Theses by an authorized administrator of DigitalCommons@URI. For more information, please contact digitalcommons-group@uri.edu. 
ARE FULL-LENGTH mRNA IN Bos taurus SPERMATOZOA TRANSFERRED TO THE OOCYTE DURING FERTILIZATION?

BY

ELIZABETH J ANDERSON

A THESIS SUBMITTED IN PARTIAL FULFILLMENT OF THE

REQUIREMENTS FOR THE DEGREE OF

MASTER OF SCIENCE

IN

BIOLOGICAL AND ENVIRONMENTAL SCIENCE

UNIVERSITY OF RHODE ISLAND

2013 
MASTER OF SCIENCE IN BIOLOGICAL AND ENVIRONMENTAL SCIENCE THESIS

$\mathrm{OF}$

ELIZABETH J ANDERSON

APPROVED:

Thesis Committee:

Major Professor

Becky L. Sartini, Ph.D.

Katherine Petersson, Ph.D.

Steven Irvine, Ph.D.

Nasser H. Zawia, Ph.D.

DEAN OF THE GRADUATE SCHOOL

UNIVERSITY OF RHODE ISLAND

2013 


\begin{abstract}
This thesis focuses on the discovery of full-length mRNA transcripts in Bos taurus spermatozoa. The primary aim of this study is to identify and validate fulllength mRNA primarily from RNA-Sequencing of bovine spermatozoa. The secondary aim is to determine if full-length spermatozoal transcripts are delivered to the oocyte at fertlilization, allowing for future studies to track their inheritance from paternal sources to the embryo. The main hypothesis of this thesis is that full-length mRNA transcripts exist within the spermatozoal transcript profile in Bos taurus. The secondary hypothesis is that if spermatozoal mRNA is functional after fertilization, then full-length transcripts should be present in the early stage embryo. To examine these hypotheses, this thesis is divided into three main chapters.

The first is a literature review, discussing the process of spermatogenesis, the unique properties of spermatozoal mRNAs, including some hypothesized functions of spermatozoal mRNAs. A summary of a new technique, RNA-Sequencing, will be discussed in this review as well as comparisons to previous literature techniques for identifying mRNA transcripts of interest.

The second chapter is the manuscript published in the journal Biology of Reproduction in January 2013, co-first-authored by Christopher Card. This manuscript uses the technique RNA-Seq to examine the transcript profile of nine Bos taurus bulls, and highlights several transcripts of interest for further study. This study found 6,166 total transcripts, and performed Gene Ontology analysis of the transcripts to categorize them into functional categories for further examination, the top most category of interest being translation.
\end{abstract}


The third chapter of this thesis is a manuscript in preparation, formatted for submission to the journal of Molecular Reproduction and Development. This manuscript evaluates twenty four target mRNA transcripts to see if they are fulllength. These transcripts were identified through four main methods: their location on the Y chromosome, their high expression in the RNA-Seq data set from chapter 2, their presence in Gene Ontology categories of interest from chapter 2, and their discovery from previous literature studies. Sixteen transcripts are found to be fulllength, eight are degraded, and four have alternative polyadenylation ends.

In conclusion, several full-length transcripts were found in this study, which have the potential to create functional proteins downstream in the fertilized oocyte. Several transcripts were also proved to be degraded in the mature spermatozoa. This has confirmed the need for this type of study, and elucidates new transcript targets for further research to pursue. 


\section{ACKNOWLEDGMENTS}

I would like to thank Dr. Becky Sartini for her continuous support both scientifically and emotionally, throughout the process of developing my master's thesis. Additionally, the members of my lab have made my years here at URI much more enjoyable and productive: Justin Richard, Erin Aparicio, Krystle Schultz, and Jazmin Zamberlan. Particular to thanks to Christopher Card, who has been an excellent collaborator and mentor throughout my masters degree.

Without the personal support of my amazing husband, and love of my life, Edward Anderson, my commitment to these manuscripts would have been much more difficult. My parents and sister have been a continual source of support throughout this process as well.

Last, but certainly not least, I would like to thank all of the mentors that I have had the pleasure of working with during my time at URI. To my committee members, Dr. Katherine Petersson, Dr. Steven Irvine, and Dr. Ingrid Lofgren, I appreciate the time, effort, and patience involved with reading and working through my thesis. I would also like to thank the teachers I've worked with: Fred Launer, Emma Kaiser, and Marta Gomez-Chiarri. 


\section{PREFACE}

The content of this thesis is subdivided into two different manuscripts. The first is a manuscript co-authored with Christopher Card and published in January 2013 in the journal "Biology of Reproduction." Liz was a co-first author on this manuscript with a primary focus on identification of full-length transcripts in the bovine spermatozoal transcript profile. She was also responsible for all gene ontology analysis. Liz was responsible for tables 3, 5, 6, and figure 3, and collaborated with Chris Card on figures

$1,3,4$, and tables 1,2 , and 4 . The writing and editing of the manuscript was shared equally between Chris and Liz.

The second manuscript here is in preparation for submission to the journal "Molecular Reproduction and Development." This work is done entirely by Liz. 


\section{TABLE OF CONTENTS}

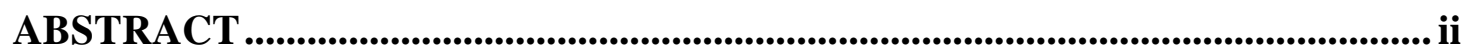

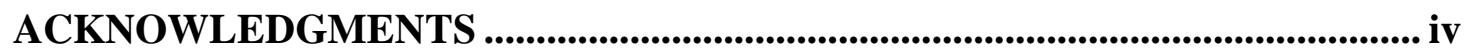

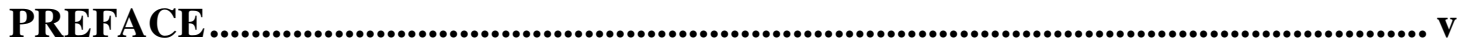

LIST OF FIGURES ............................................................................................................ xii

CHAPTER 1: LITERATURE REVIEW............................................................... 1

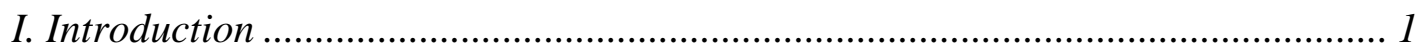

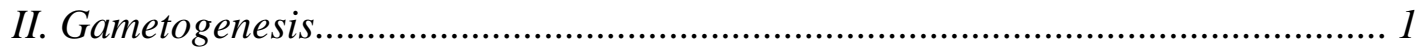

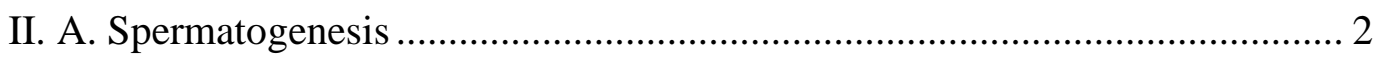

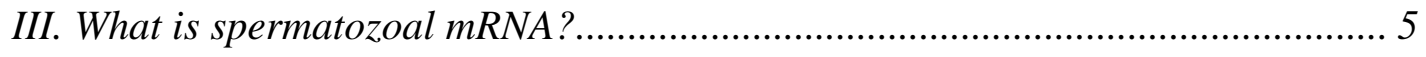

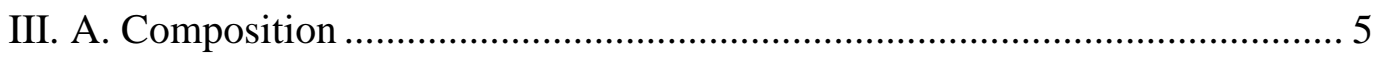

III. B. Potential Functions of Spermatozoal mRNA …….................................... 7

III.B.1. Spermatozoal survival in the female reproductive tract and fertilization

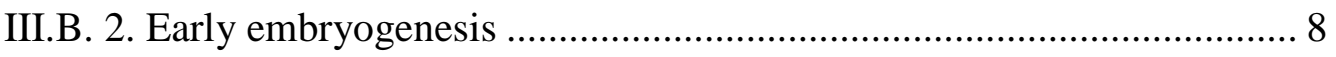

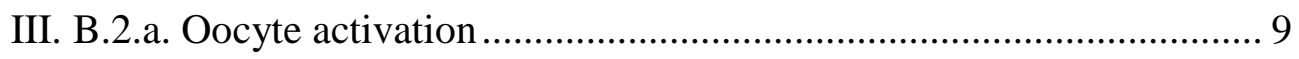

III. B.2.b. Protamines: chromatin repackaging \& regulation ......................... 10

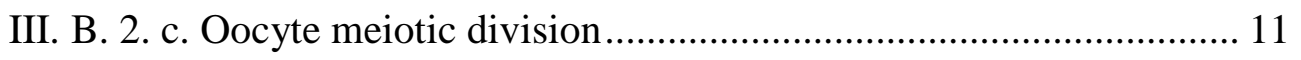

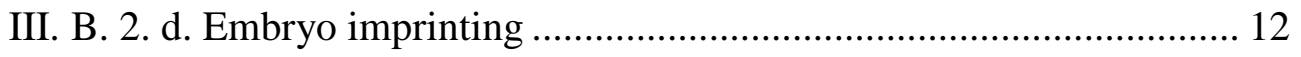

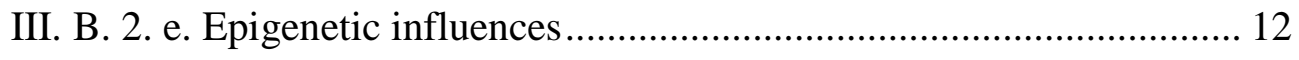

III. B. 2. f. Regulating proper embryo development ..................................... 13 
III. B. 3. Spermatozoal mRNA use as a fertility assay

IV. Full-Length mRNA Transcripts.

V. RNA-Seq: a global transcript discovery method …....................................... 17

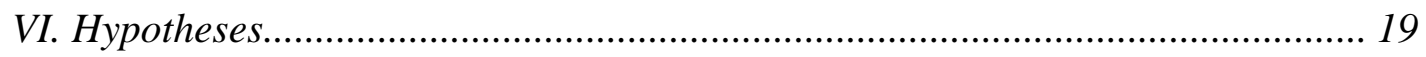

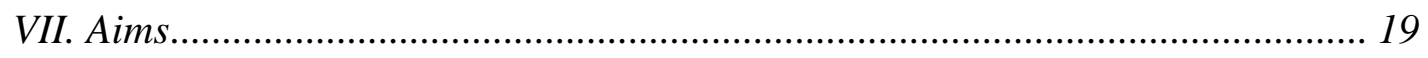

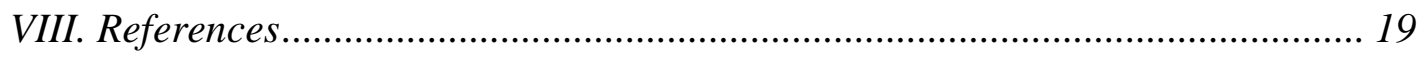

CHAPTER 2: BIOLOGY OF REPRODUCTION MANUSCRIPT .................... 28

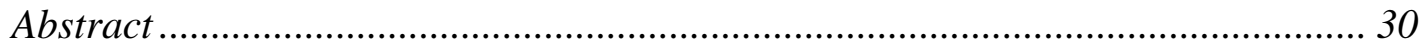

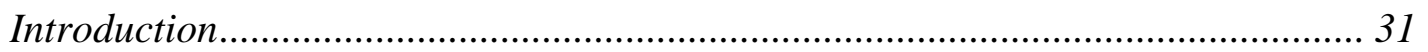

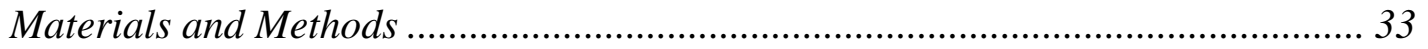

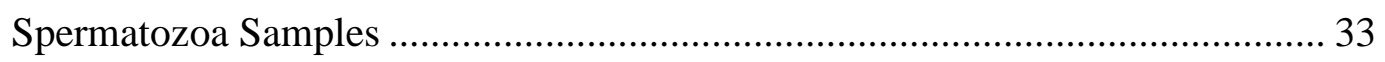

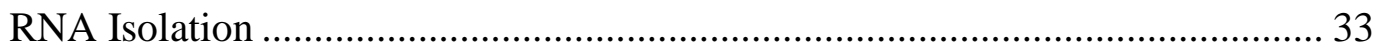

Double-Stranded cDNA (ds-cDNA) Synthesis and Amplification ..................... 34

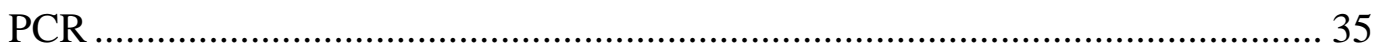

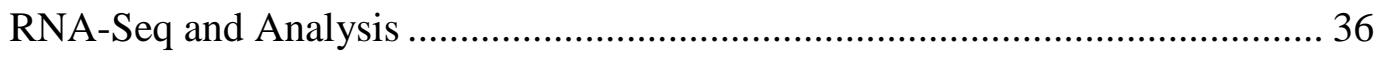

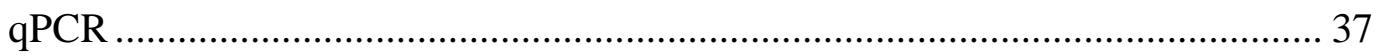

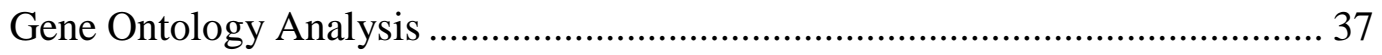

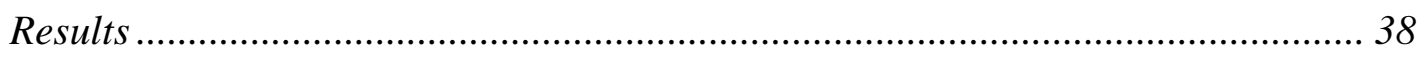

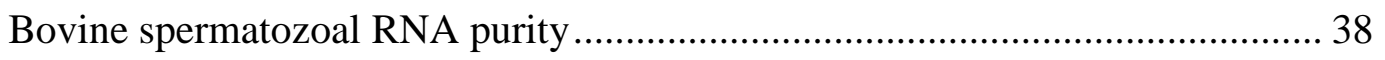

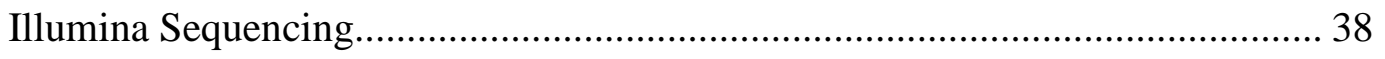

Cryopreserved Bovine Spermatozoal Transcript Profile ................................... 39 
Gene Ontology Analysis

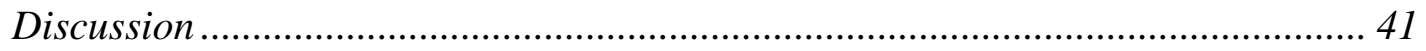

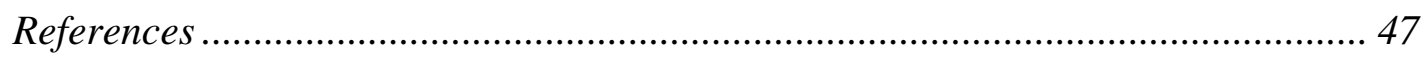

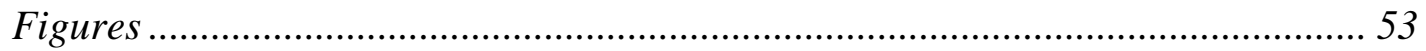

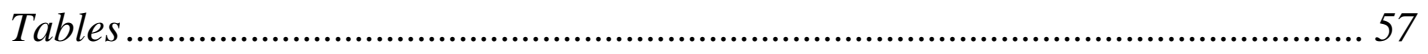

\section{CHAPTER 3: MOLECULAR REPRODUCTION AND DEVELOPMENT}

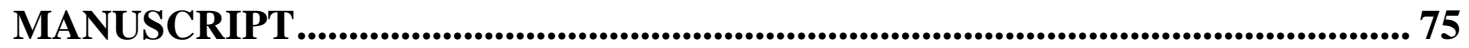

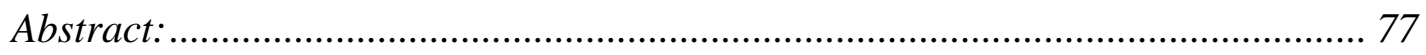

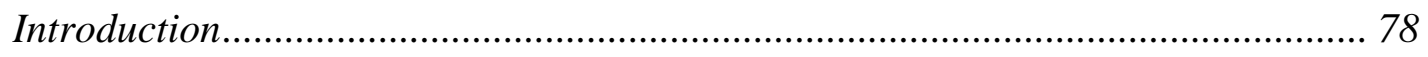

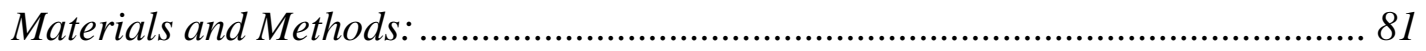

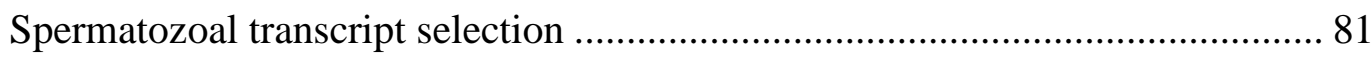

cDNA Amplification \& Standard RT-PCR …........................................... 84

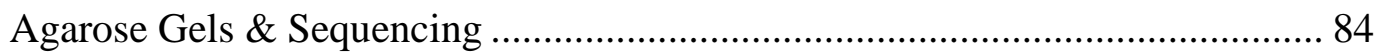

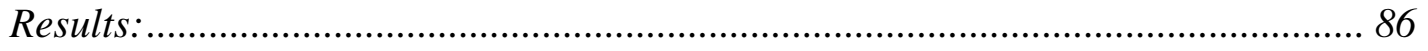

Discussion:

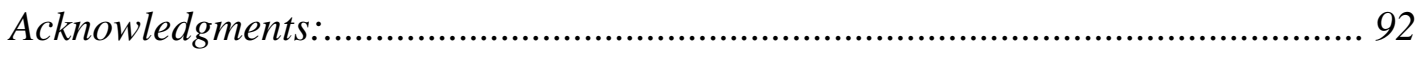

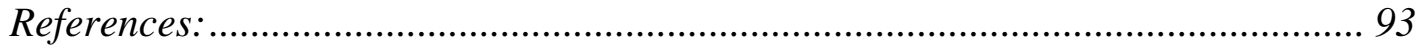

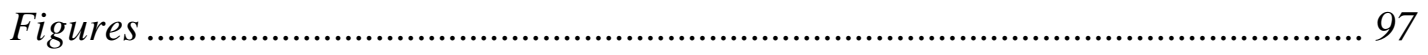

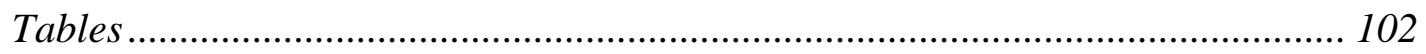

APPENDICES …...................................................................................................................... 107 


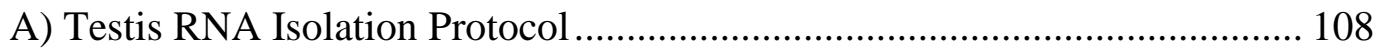

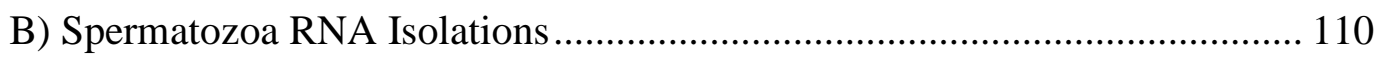

C) Oocyte \& Embryo RNA Isolations ................................................................. 111

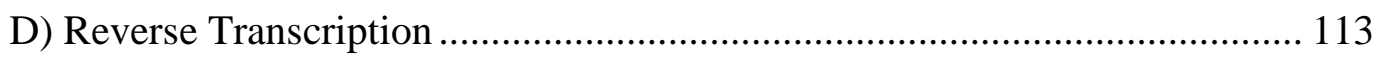

Centrifuge briefly and use immediately for amplification or store at $-20^{\circ} \mathrm{cE}$ )

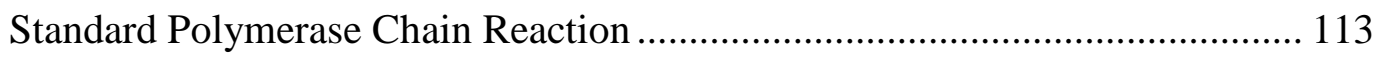

E) Standard Polymerase Chain Reaction ...................................................... 114

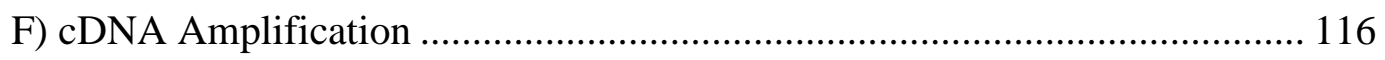

G) Rapid Amplification of cDNA Ends Polymerase Chain Reaction ............... 123

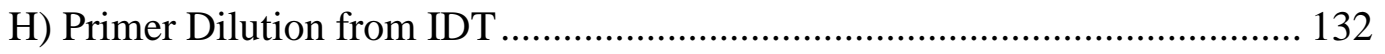

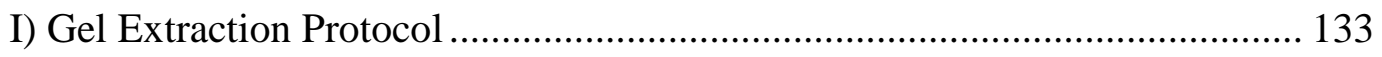

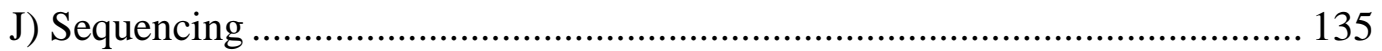

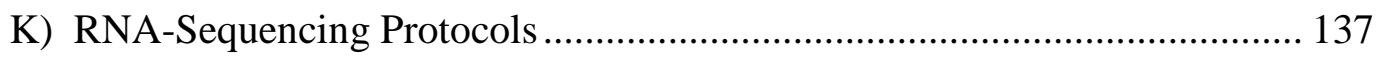

APPENDIX II: RAW APE FILES USED FOR CHAPTER 2 ………................... 142 


\section{LIST OF TABLES}

CHAPTER 2:

TABLE

PAGE

Table 1. Bovine primer sequences. *Genomic DNA amplicon which includes 144 bp

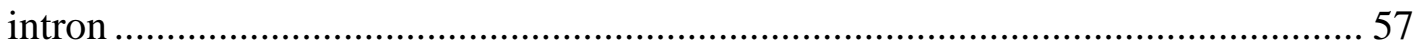

Table 2. Top 10 bovine spermatozoal transcripts based on FPKM.......................... 58

Table 3. Comparing 5' and 3' exons in transcripts from previous literature ..............59

Table 4. Top 10 previously unreported full-length bovine spermatozoal transcripts based on FPKM. 60

Table 5. Top 10 gene ontology categories for all spermatozoal transcripts FPKM>0 and for transcripts with FPKM>100. CP = Catabolic Process, $\mathrm{Bi}=$ Binding, Org $=$ Organelle, NMBO = Non-Membrane Bounded Organelle, TTA $=$ transmembrane transporter activity.

Table 6. Full-Length Trasncripts for the population of FPKM $>100$ 62 


\section{CHAPTER 3:}

TABLE

PAGE

Table 1

Transcript identification methods. Lit=Literature Searches, Y Csome $=$ Y chromosome located, $\mathrm{GO}=$ found in gene ontology translation category 102

Table 2

Primers Used for PCR Amplification 103

\section{Table 3}

Sequencing of bovine sperm transcripts where base pairs matched the predicted transcript using primers in Table $1 . \mathrm{Y}=\mathrm{Yes}, \mathrm{N}=\mathrm{No}, \mathrm{n} / \mathrm{a}=$ no poly(A) present in genbank accession, $*$ = Poly A tail is present but not where the original accession number indicates it. A) full-length transcripts B) degraded transcripts 105

\section{Table 4}

Transcript presence in testis, sperm, oocyte and embryos from published microarray studies. $\quad \mathrm{Y}=$ transcript present, $\mathrm{N}=$ transcript absent, $\mathrm{M}=$ results inconclusive. Oocyte \& Embryo microarray data are from Kocabas et al. 2006. Testis and sperm microarray data are from Chalmel et al., 2007 106 


\section{LIST OF FIGURES}

CHAPTER 1:

FIGURE

PAGE

Figure 1

Spermatogenesis 4

Figure 2

Diagram of a full-length mRNA transcript. UTR $=$ Untranslated Region 16

\section{Figure 3}

RNA-Seq Methodology A) Transcripts are fragmented into many pieces, with adaptors attached to both ends, adaptors shown in blue and red. B) Example of RNA-Seq read alignment to a reference genome after sequencing. Exons depicted are categorized into three major categories, shown at bottom. 18

CHAPTER 2:

FIGURE

PAGE

Figure 1. Purity of bovine cryopreserved spermatozoal RNA was confirmed by lack of somatic cell RNAs and genomic amplification. (A) Bioanalyzer analysis of testis RNA and spermatozoal RNA prior to amplification. (B) Cell-specific transcripts for testicular germ cells $(C-K I T)$, leukocytes $(C D 45)$ and epithelial cells $(C D H 1)$ 
did not amplify in the spermatozoal RNA (Lane $\mathrm{S}$ ). $\mathrm{M}=100 \mathrm{bp}$ DNA marker, $\mathrm{T}=$ testis RNA positive control and $\mathrm{N}=$ negative control that does not include cDNA template. (C) The spermatozoal RNA (Lane S) does not contain genomic DNA compared to amplification of genomic EIF1 in spermatozoal cDNA spiked with genomic DNA (Lane G). $\mathrm{N}=$ negative control that does include cDNA template. 53

Figure 2. Correlation of qPCR transcript copy number and RNA-Seq FPKM........... 54

Figure 3. PCR amplification of (A) the 5' and 3' ends of DDX3Y, PLCZ1, CRISP2 and GSTM3 in amplified ds-cDNA. For 5' end primers, all primers begin in the first exon, and for 3' end primers, all primers end in the last exon. All primer sets are intron-spanning. $\mathrm{N}=$ negative control that did not include $\mathrm{cDNA}$ template and $\mathrm{M}=$ 100 bp DNA marker. (B) Transcripts for GSTM3 and GTSF1 were PCR amplified using primers within the first and last exons in order to capture full-length transcripts. The cDNA for this section was used from the 3-bull pool created from a Superscript III Reverse Transcription of mRNA (Invitrogen, Carlsbad, CA) ......... 55

Figure 4. PCR amplification of select transcripts in individual bull sperm amplified 56

\section{CHAPTER 3:}

FIGURE

PAGE

\section{Figure 1}

Alignment of sperm transcript RNA-Seq reads (bottom line) with bovine genome in UCSC Mappings (Meyer et al. 2013) using bovine sperm RNA-Seq data from (Card et al. 2013) for bovine sperm transcripts assayed in this study. 
Untranslated Regions (UTRs) are included in all transcripts shown here as thinner black lines at both ends of each transcript. RNA-Seq mappings don't show separate UTRs and have a continuous thick black line. Summary of read mappings indicating full-length (all exons mapped) or degraded transcripts (exons missing) is indicated on the right. Extra exons sequenced in RNA-Seq but not visualized in the bovine genome are also indicated.................................. 97

\section{Figure 2}

Full-length bovine spermatozoal transcripts A) Transcripts sequenced from a single amplicon, spanning from 5' exon to the 3' exon. B) Transcripts sequenced from two overlapping amplicons, bands shown that cover 5' and 3' ends C) Transcript sequenced from three overlapping amplicons, from 5' to midsection to 3' ends. D) Full-length transcript found with an alternative 3'UTR. Negative

control $=$ no template 99

\section{Figure 3}

Degraded transcripts present in the bovine sperm transcript profile. A) Transcripts with degradation, amplicons sorted by 5' to 3' end location. B) Transcripts degraded on the 5' end, as well as having alternative 3'UTR. ATPase $\beta$ and CHMP5 have only one band, but the band size and location of the poly(A) tail were different from the reference accession. Negative control = no template... 100

Figure 4: Oocyte and 2-Cell Embryo PCRs. All genes are arranged in order from left to right that the PCRs were performed. $\mathrm{CO}=\mathrm{cDNA}$ oocyte, $\mathrm{CE}=\mathrm{cDNA} 2$-cell embryo, NT= No Template Control, NR= No RT Template Control, RO=RACE oocyte, RE=RACE 2-cell embryo, $\mathrm{Sp}=$ Sperm cDNA from 9-bull pool 101 


\section{CHAPTER 1: LITERATURE REVIEW}

\section{$\underline{\text { I. Introduction }}$}

The presence of messenger RNA (mRNA) in transcriptionally-silent spermatozoa was initially discovered in 1989 (Pessot et al. 1989). While most information is known about spermatozoa creation and spermatozoal DNA, little is known about the mRNAs contained within spermatozoa and their function. The primary focus of this thesis is the composition of the spermatozoal mRNA and the potential contributions of the spermatozoa to the oocyte at fertilization. Specifically of interest to this study is whether or not the mRNAs contained within spermatozoa are functional, or simply degraded remnants. A summary of what RNAs are present in spermatozoa is presented here, as well as several hypotheses as to the functions that these spermatozoal mRNAs might serve. Following discussion of the spermatozoal RNAs, this review will examine a new method for identifying RNA transcripts of interest, called RNA-Seq, which was used for the Chapter 2 Biology of Reproduction publication. This will include a comparsion with previous methods for identifying RNAs. This review will conclude with the hypotheses and aims of this study.

\section{Gametogenesis}

Both males and females create specialized reproductive cells through the process of gametogenesis. Many mechanisms are shared between spermatogenesis (the generation of male spermatozoa) and oogenesis (generation of female oocytes). Foremost, diploid stem cells in both males and females divide through mitosis and meiosis I and II into four haploid cells. In spermatogenesis, all four haploid cells mature into individual spermatozoa. In oogenesis, three of the four haploid cells form 
polar bodies that are discarded as the oocyte matures, until it contains only a single haploid nucleus. Meiosis also increases the genetic variation between the haploid cells through homologous recombination (Schlecht and Primig 2003; P.L.Senger 2005). Similar hormonal mechanisms are also used for spermatogenesis and oogenesis, with gonadotropin releasing hormone and lutenizing hormone acting as triggers for germ cell release in both processes (Holstein et al. 2003; P.L.Senger 2005).

Despite these basic similarities between spermatogenesis and oogenesis, the two processes achieve their reproductive goals through two very different methods. The main difference is that only males have a self-renewing system, which enables them to create much greater numbers of gametes compared to females (Holstein et al. 2003), discussed below. Unlike spermatozoa, the stem cells that create oocytes are incapable of self-renewing post-natally (Kocabas et al. 2006). For an oocyte to mature, they have to halt cell death, activate maternal transcription, unpack paternal DNA, and then kick-start embryo development (Potireddy et al. 2006). Once the spermatozoa fuse with the oocyte, the spermatozoa may be able to assist the oocyte with some of these functions. The maternal contribution produces a limited number of oocytes, but invests more energy into the production of oocytes with large biomass (Hayward and Gillooly 2011). In contrast, the paternal strategy focuses on the production of massive quantities of spermatozoa.

\section{A. Spermatogenesis}

Spermatogenesis is the process that spermatogonial stem cells undergo in the testis to mature into functional spermatozoa which is supported by Sertoli nurse cells (Figure 1; Petersen et al., 2006; Zhang et al., 2012),) To compensate for the need to 
make large quantities of spermatozoa, males use a self-renewing stem cell system to allow for production of spermatozoa from sexual maturity up until death. To this end, spermatozoa develop from a group of stem cells in the testis, which are capable of self-renewal through continuous mitosis (Holstein et al. 2003). The developing germ cells then enter meiosis I and II, now called spermatocytes, and, after a final homologous recombination event, become haploid round spermatids (Iguchi et al. 2006).

During the early round spermatid stage of the second meiosis, a significant increase of transcription and translation also occurs, depositing all the mRNAs the mature spermatozoa will maintain (Braun 2000; Eddy 2002; Holstein et al. 2003). From this point forward in spermatogenesis, the spermatids become transcriptionally silent and cease making mRNAs, although new proteins are later produced for the morphological changes necessary for mature spermatozoa formation. Several transcripts that remain in round spermatid are modified through post-transcriptional mechanisms in the 5' and 3' untranslated regions to hold them in an inactive state for later translation (Braun 1998). This is regulated by accessory proteins such as Tarbp2 (Braun 2000), and is known to be used on the transcripts PRM1 and PRM2 (Mali et al. 1989). 


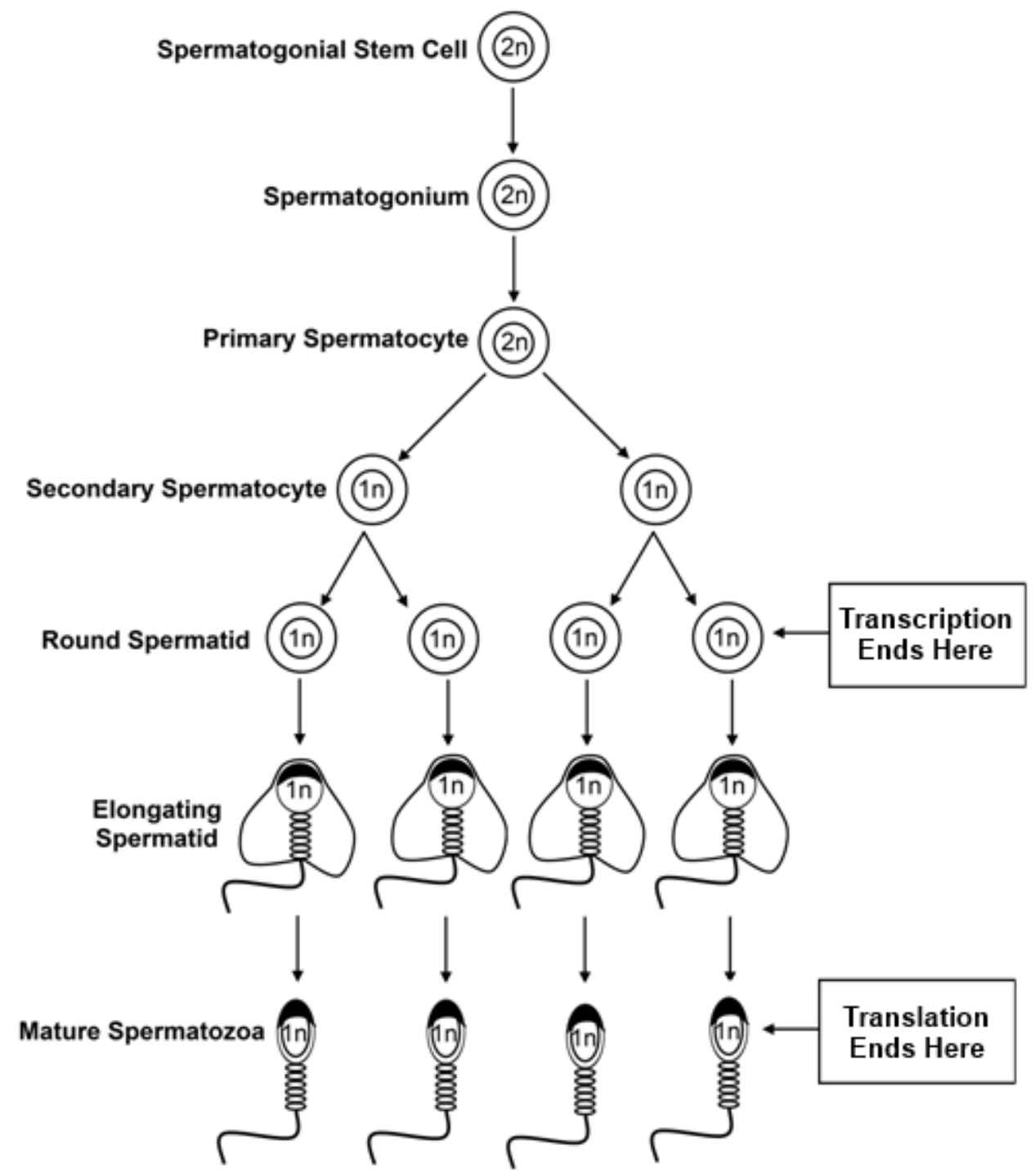

Figure 1: Spermatogenesis

The final differentiation of the developing spermatozoa cell occurs as the morphological changes create the spermatozoa head and tail. During this differentiation, round spermatids undergo a final process called cyto-differentiation, where the cells condense their nucleus, form an enzyme cap to help with fertilization, and develop the motor flagella needed for locomotion (Holstein et al. 1988). As the cytoplasm is lost in this elongating spermatid, the spermatozoa lose the ability to 
translate mRNAs into proteins, but the population of silenced mRNAs remain. Some silenced transcripts, from the elongating spermatid stage, are translated at this stage of development in order create new proteins to facilitate head and tail development. The final packing of the DNA occurs as spermatogenesis concludes, and the spermatozoa are released into the seminiferous tubule for their journey through the female reproductive tract (Dadoune et al. 2004).

Throughout the process of spermatogenesis, several unique mechanisms are utilized to regulate temporal and quality control of the spermatozoal mRNAs. Transcriptional silencing, discussed above, is one of the standard mechanisms used to regulate timing of mRNA transcript use during spermatogenesis (Braun 2000). Around the same time that selective mRNAs are being silence, the developing spermatozoa also performs DNA-repair and apoptosis to ensure quality of the mature spermatozoa (Smirnova et al. 2006). Prior to nuclear condensation ubiquitin-mediated proteolysis removes selective proteins from the cell, is responsible for replacing histones with sperm-specific protamines (Sutovsky 2003), and degrades selective mRNAs in the developing embryo (Thompson et al. 2003). The exact percentage of spermatozoa mRNAs that are degraded is unknown. When these regulatory mechanisms malfunction, the spermatozoal quality and fertility decrease (Foote 2003).

\section{What is spermatozoal mRNA?}

\section{A. Composition}

The focus of this thesis is investigating the existence of full-length transcripts in bovine spermatozoa thus providing more evidence that spermatozoa mRNAs may be functional. Spermatozoa carry not only paternal DNA, but also paternal RNAs to 
the oocyte at fertilization, but no previous studies have examined whether these mRNAs are full-length, a prerequisite for functionality as a protein. Finding the functionality of these transcripts is particularly interesting since spermatozoa are translationally silent at maturity, indicating that they are incapable of utilizing these mRNAs themselves (Miller and Ostermeier 2006).

Although the pool of spermatozoal RNAs is small, it contains a variety of different RNAs, including: mRNAs, rRNA, and siRNAs (Boerke et al. 2007). The function of some spermatozoal RNAs are known. For example, selective rRNA transcripts for ribosome proteins are retained or degraded through specific cleavage in the spermatozoa (Johnson et al. 2011b). The lack of complete ribosomes is one of the reasons why translation is not possible in the mature spermatozoa. Another type of RNAs found in spermatozoa is siRNAs, which have been demonstrated to be stable all the way until the activation of the embryonic genome (Kono et al. 2004). In addition, sperm-derived siRNAs have been shown to imprint on male germ cells (Reik and Walter 2001), and can modulate embryonic gene expression (Mao et al. 2002). Spermatozoal microRNAs such as microRNA-34c are also known to impact functionality in embryo development by regulating the first cellular division of the embryo (Liu et al. 2012).

This thesis focuses on the population of mRNAs in spermatozoa. The precise number of mRNAs contained per spermatozoa is unknown, but has been estimated to be approximately 3000-7000 transcripts (Ostermeier et al. 2002; Gilbert et al. 2007; Das et al. 2010), or approximately 5-10 fg per spermatozoa. This minimal amount of mRNA per spermatozoa makes detection of the mRNA difficult (Boerke et al. 2007). 
The location of the spermatozoal mRNAs may provide a clue to the function. While the majority of spermatozoal mRNAs are located in the nucleus, a limited number of mRNAs are located in other areas. For example, SP17 is expressed in the flagellar fibrous sheath (Chiriva-Internati et al. 2009). The protein made by the transcript SMCY is present on the surface of spermatozoa (Yao et al. 2010a). The mRNAs located on the outside of the nucleus may be more likely to have an impact on the act of fertilization or spermatozoa survival, rather than on embryogenesis, but it is not known if and where they are translated into protein.

\section{B. Potential Functions of Spermatozoal mRNA}

It was originally thought that the mRNAs in spermatozoa were just a remnant of the spermatogenesis process, but newer evidence supports the translation and function for these silenced mRNAs during fertilization and early embryonic development. The presence of regulatory mechanisms for mRNA timing also lends credence to the idea that the maturing spermatozoa may in fact be preserving them for later use.

There are a variety of hypothesized functions for spermatozoal mRNAs. Spermatozoa from several species have been examined using microarrays, although the most common are humans (Ostermeier et al. 2005; Chalmel et al. 2007; GarcíaHerrero et al. 2010), rodents (Smirnova et al. 2006; Chalmel et al. 2007; Yao et al. 2010b; Liu et al. 2012), and bulls (Gilbert et al. 2007; Bissonnette et al. 2009; Vigneault et al. 2009; Feugang et al. 2010). 
Some common spermatozoal transcripts among these species include $P R M 1$, $C L U$, PGK2, AKAP4, PRM2, H2AFZ, COX7A2, and DNMT1. Several of the functions hypothesized from these mRNAs are discussed below, and largely focus on mRNA functions in fertilization, embryogenesis, or as a tool for fertility assays.

\section{III.B.1. Spermatozoal survival in the female reproductive tract and fertilization}

It is hypothesized that the translation of some spermatozoa mRNAs facilitate spermatozoa maturation in the female tract, known as capacitation, rather than impacting the embryo's development. By assisting with spermatozoa survival and the act of fertilization, these spermatozoa may influence fertility without ever impacting the embryo directly (Killian 2012). As stated previously, mature spermatozoa lack the cytoplasmic ribosomes to translate spermatozoal mRNAs but limited data suggest translation may occur in the spermatozoa mitochondria. Interestingly, there is some limited evidence that some spermatozoal nuclear-encoded mRNAs are translated in the mitochondria in the tailpiece of the spermatozoa, only occurring right before fertilization and right after the spermatozoa undergo capacitation (Gur and Breitbart 2008). Other spermatozoal proteins such as CRISP2, CCT8, and PEBP1 may assist with sperm-egg fusion during fertilization although it is not yet known if the spermatozoal transcripts themselves are also translated and contribute to this role in capacitation and fertilization (Arangasamy et al. 2011).

\section{III.B. 2. Early embryogenesis}

After the introduction of the paternal genome at fertilization, there is a lag time before the activation of the embryonic genome when the maternal genome maintains 
activity in the early zygote. In Bos taurus, the transition from maternal gene expression to zygotic gene expression occurs approximately 62 hours after fertilization (Memili and First 2000). Prior to this transition, the oocyte is responsible for mRNA and protein synthesis, helping with both maternal and paternal gene organization, and aiding the fusion of two pronuclei to form the zygotic nucleus (Potireddy et al. 2006). Due to this lag time in the activation of the embryonic genome, it has been hypothesized that spermatozoal mRNAs might function before activation of the embryonic genome (Ostermeier et al. 2002). This is supported by experiments that demonstrated that specific spermatozoal mRNAs are transferred to the oocyte at fertilization including clusterin $(C L U)$, protamine 2 (PRM2), protamine 1 (PRM1), and DDX3Y (Ostermeier et al. 2002; Swann et al. 2006; Kempisty et al. 2008a) although a specific function for these spermatozoal transcripts has not been determined, and several are likely degraded rapidly upon entering the oocyte.

\section{B.2.a. Oocyte activation}

One of the only definitive functions for spermatozoal mRNA is oocyte activation at fertilization, caused by the specific transcript PLCZ1. PLCZ1 triggers calcium oscillations in the oocyte. This activation occurred both when the RNA was injected into the oocyte (Saunders et al. 2002; Rogers et al. 2004), and when the protein was injected (Swann et al. 2006). The egg activation causes the oocyte to finish maturing and triggers the transition to embryonic genome control (Boerke et al. 2007). This transcript appears to be highly conserved, occurring in animals from drosophila to humans (Fischer et al. 2012). 


\section{B.2.b. Protamines: chromatin repackaging \& regulation}

During spermatogenesis, histones are replaced by transition proteins and then finally by protamines. Protamines $P R M 1$ and $P R M 2$ are responsible for replacing histones to package DNA at the end of spermatogenesis, so regulation of these specific transcripts will have a large impact on how chromatin gets packaged (Mali et al. 1989). The manner in which genes are packaged depends on how they might be used, with selective components of the DNA remaining loosely wound for access by translational machinery (Miller et al. 2005; Miller and Ostermeier 2006; Carrell and Hammoud 2010; Arangasamy et al. 2011; Ellis et al. 2011; Johnson et al. 2011b; Hamatani 2012). Spermatozoal mRNAs might assist with this organization through the use of the mRNAs as a structural component, acting to expose areas of DNA and preventing them from being wrapped up as tightly in the mature spermatozoa (Wykes et al. 1997).

Aside from repackaging the spermatozoal DNA, the protamines are responsible for temporal control of protein synthesis in developing spermatozoa. This is accomplished by creating the protamines early in spermatogenesis, and then silencing them until they are needed for nuclear condensation at the end of spermatogenesis (Braun 2000). PRM1 is highly conserved and has been found in spermatozoa of mice (Eddy 2002; Rassoulzadegan et al. 2006; Johnson et al. 2011a), cows (Gilbert et al. 2007; Lalancette and Miller 2008; Bissonnette et al. 2009; Feugang et al. 2010; Hecht et al. 2010; Ganguly et al. 2012; Card et al. 2013), humans (Ziyyat et al. 1999; Avendaño et al. 2009; Carrell and Hammoud 2010; Johnson et al. 2011a; Hamatani 2012; Jodar et al. 2012), and marmosets (Hecht et al. 2010). Of the 
transcripts previously studied, protamine 1 (PRM1) is also one of only a few that have been investigated in multiple species, and proven to be transferred to the oocyte in Bos taurus (Hecht et al. 2010). Although PRM1 mRNA is transferred from the spermatozoa to the oocyte at fertilization, a functional role is unlikely because related PRM2 has been demonstrated to be rapidly degraded in the oocyte (Avendaño et al. 2009). The ability to detect PRM1 in the oocyte is likely due to its critical function in spermatozoa maturation, which leaves many copies of the PRM1 and PRM2 transcripts untranslated in the spermatozoa after maturation.

Despite PRM1 likely being a non-functional spermatozoal mRNA in the oocyte and embryo, it has a potential for use in a fertility assay that represents gene expression during spermatogenesis (see Fertility section below), even if found in a degraded state (Gilbert et al. 2007). Protamines are also useful candidates for tracking mRNA inheritance patterns because they are sperm-specific (Kempisty et al. 2008b; Hecht et al. 2010).

\section{B. 2. c. Oocyte meiotic division}

One way that spermatozoal mRNAs may impact embryogenesis is through control of the cell cycle, such as preventing or promoting the timing of cell divisions. For example, the microRNA-34c has been demonstrated to be responsible for the first cleavage of the embryo in mice. MicroRNA-34c is also known to be carried by the spermatozoa rather than the oocyte (Liu et al. 2012). This demonstrates that at a basic level, spermatozoa determine the timing of development. 
Other transcripts directly regulate the cell cycle, such as $C K S 2$ that is involved in the MI anaphase transition in the cell cycle. Mutations present in this gene are responsible for sterility in both men and women (Donovan and Reed 2003). Cell cycle regulation is very important in early embryo development because it helps to determine when the embryo will overtake its own gene expression and cease using paternal or maternal sources of mRNAs and proteins (Hecht et al. 2009).

\section{B. 2. d. Embryo imprinting}

In reproduction, an eternal arms race exists between which copy of a gene will be used by the embryo: the maternal copy or the paternal copy? A large portion of this is controlled by a process called imprinting, which marks which copy of the allele to use by methylating the unused gene copy (Jenkins and Carrell 2012). This process is thought to be partially controlled by spermatozoal antisense RNAs, which act to maintain and protect the paternal copies of genes from degradation mechanisms as they enter the oocyte. The RNAs are hypothesized to work through the formation of a transcriptional silencing complex, which tags paternal DNA for imprinting in the oocyte (Miller and Ostermeier 2006).

\section{B. 2. e. Epigenetic influences}

There are many different ways that spermatozoal mRNAs might help the earliest stages of fertilization to establish and maintain the paternal genome (Miller et al. 2005). This touches on the idea of selfish genes: that the mRNAs of the father may be acting to further paternal interests, while maternal mRNAs compete against them. 
This may also explain why certain transcripts are expressed highly and selectively in spermatozoa versus oocytes (Kleene 2005).

An expanding field of interest as to the mechanism of these changes is the field of epigenetics. Epigenetic changes are changes in the genetics or phenotype resulting from modifications other than to the underlying DNA. This is to say that epigenetics are post-processing modifications made to DNA, mRNAs, and proteins that affect areas other than the DNA coding (see Figure 2 below). Epigenetic modifications have been linked to cases of male infertility, and commonly occur through histone modifications and DNA methylation (Carrell and Hammoud 2010). RNAs are partially responsible for the control of this DNA methylation, with Kit mRNA knockouts resulting in heritable epigenetic changes in mice offspring, although the precise mechanism of change is unknown (Rassoulzadegan et al. 2006).

\section{B. 2.f. Regulating proper embryo development}

After fertilization, some transcripts from spermatozoa may still exist that can impact the developing embryo. Transcripts for the proteins HLA-E, PSGI, and PRM2 are found in spermatozoa from fertile men have been demonstrated to have an impact on embryo implantation and development, although the length of duration of the action is limited to approximately 24 hours after fertilization, at which point the first polar body is released (Avendaño et al. 2009).

Another spermatozoal transcript that is delivered to the oocyte at fertilization is $D D X 3 Y$. DDX3Y is a DEAD-box RNA helicase, and is one of 33 total genes found on the Y chromosome (Marshall Graves 2000), which also has an X chromosome 
homolog (Vong et al. 2006). The $\mathrm{X}$ homolog of $D D X 3 Y$ also shares in similar functions, but it has been demonstrated that when the X-encoded isoform is mutated, that $D D X 3 Y$ is capable of rescuing some of the functionality for the embryo (Sekiguchi et al. 2004). $D D X 3 Y$ is located in a known azoospermia region on spermatozoa, a region known for causing infertility in the spermatozoa when damaged (Session et al. 2001; Vong et al. 2006). In mature spermatozoa, DDX3Y is localized to the post-acrosomal region of sperm, and injection of as- $D D X 3 Y$ into the oocyte nucleus has been correlated with decreased embryo development rates (Yao et al. 2010b).

\section{B. 3. Spermatozoal mRNA use as a fertility assay}

Assessing fertility of spermatozoa has been limited to tests of morphology, motility, and concentration (Lalancette and Miller 2008; Feugang et al. 2010). These measurement of spermatozoa function are incapable of predicting whether the spermatozoa possess the ability to survive the female reproductive tract, fertilize an

egg, or even produce a viable embryo (Sutovsky 2003; Bissonnette et al. 2009). Due to this problem, finding more quantitative measures of fertility is highly desirable. By identifying spermatozoal mRNAs, we are not only provided with information about their potential function, but may also find uses for them as diagnostic measures of fertility for individuals. The mRNAs produced by an individual are consistent from ejaculate to ejaculate, and vary between individuals, making them a stable target for a fertility assay (Das et al. 2010). In addition, the amount of individual transcripts CRISP2, CCT8, and PEBPI has been correlated with relative fertility of individual bulls (Arangasamy et al. 2011). The efficiency with which PRM1 proteins package 
DNA has also been shown to impact fertility, and is differentially expressed in fertile versus infertile bulls (Carrell and Hammoud 2010; Feugang et al. 2010; Ganguly et al. 2012; Jodar et al. 2012). The spermatozoal mRNAs may therefore be used as a snapshot of fertility, providing better diagnostic tools to examine infertility (Dadoune et al. 2004; Ostermeier et al. 2005; Lalancette et al. 2008).

As previously discussed, many of the mRNAs in spermatozoa are degraded or will be degraded rapidly in the oocyte. However, even incomplete mRNA transcripts may be used as a snapshot of fertility, and also as a predictor of infertility (Dadoune et al. 2004; Ostermeier et al. 2005; Lalancette et al. 2008). This is because the mRNAs are deposited in spermatozoa at a single timepoint, so they reflect how efficiently the spermatozoa were developing at that point. Many of the mutations in spermatozoa that would render them incapable of fertilization occur around this time (Miller and Ostermeier 2006). A few studies have indicated that degraded mRNAs are specific to an individual; they may serve as a useful fertility assay to measure relative fertility (Suri 2004; Feugang et al. 2010; Park et al. 2012). This is particularly useful for mutations that alter the genetics and transcript profiles without altering the general phenotype or motility (Foote 2003). For example, the calmegin gene is required for allowing spermatozoa to progress past the uterotubal junction in the female reproductive tract, making knockouts of the calmegin gene infertile. However, these knockouts fail to express any morphological or motility abnormalities, so they would not be detected using standard fertility assays (Yamagata et al. 2002).

\section{Full-Length mRNA Transcripts}


While some specific spermatozoal transcripts have been identified, functionally depends on the presence of intact, full-length transcripts that can be translated into proteins either in the spermatozoa or in the early stage embryo. Spermatozoal transcript profile methods, primarily microarray studies, have so far only identified the presence of transcripts but have not designated between whether the mRNA transcripts are full-length or degraded remnants of spermatogenesis. If spermatozoal mRNA is functional after fertilization, then full-length transcripts should exist within the spermatozoa transcript profile.

Figure 2: Diagram of a full-length mRNA transcript. UTR=Untranslated Region

A full-length transcript requires several parts to be translated into a functional protein (Figure 2). The coding region provides the nucleotide sequences to be translated into protein while much of the protein regulation is done by the UTRs, the 5' cap and 3' poly(A) tail. At the 5' end, a modified guanine cap is responsible for recognition of the mRNAs by ribosomes, providing the attachment for their translation and determining the efficiency with which mRNAs will be translated (Parker and Sheth 2007). The cap also influences the survival of the mRNA, by stabilizing it against degradation (Gallie 1991).

The untranslated regions (UTRs) flanking both sides of the coding region contain regulatory elements that control gene expression including post-transcriptional gene expression in the 3'UTR. Regulatory elements in the UTR impact degradation by setting the location of the stop codon that completes the mRNA, by controlling the 
tertiary structure of the protein being formed, and by regulating decay of the mRNA (Isken and Maquat 2007). The 3' UTR can also be modified or lengthened, a process called alternative polyadenylation (Danckwardt et al. 2008). These modifications can lead to several different transcript isoforms, which may be expressed simultaneously within a given individual's transcriptome (Kleene 2005). At the end of the mRNA, the 3' end poly(A) tail also contributes to the rate of mRNA degradation, and is the site of many of the epigenetic changes that occur to spermatozoal mRNAs (Rassoulzadegan et al. 2006). The new method of global transcriptome discovery, RNA-Seq, will facilitate the identification of full-length transcripts, and can detect many of the modifications to known transcripts discussed above.

\section{RNA-Seq: a global transcript discovery method}

The identification of full-length transcripts in spermatozoa is essential to identify candidate transcripts for further analysis of function. As mentioned previously, studies to date have use methods that only detect a small portion of a transcript but do not reveal if full-length transcripts are present. For example, microarrays are a hybridization-based method that can detect the presence and amount of transcript but is limited to known transcripts. An incomplete transcriptome for sperm, oocytes, and embryos has been previously reported by microarrays in humans

(Ostermeier et al. 2005; Chalmel et al. 2007; García-Herrero et al. 2010), rodents (Potireddy et al. 2006; Smirnova et al. 2006; Chalmel et al. 2007; Yao et al. 2010b; Liu et al. 2012), and bulls (Misirlioglu et al. 2006; Gilbert et al. 2007; Bissonnette et al. 2009; Thelie et al. 2009; Vigneault et al. 2009; Feugang et al. 2010). 
RNA-sequencing (RNA-Seq) is a newer high-throughput method that sequences an entire transcriptome in situ, which removes the constraints of only searching for known transcripts and can sequence the entire length of a transcript. This allows for the discovery of novel transcripts (Wang et al. 2009; Mamo et al. 2011; Driver et al. 2012). Additionally, RNA-Seq provides quantitative expression levels by assessing the number of sequencing reads mapping to a specific transcript. In RNASeq, mRNA is fragmented, sequenced in situ into reads then aligns reads to a reference genome (Figure 3), or assembles them de novo.

A)

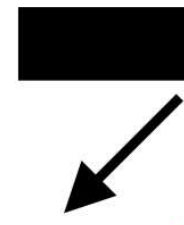

Fragment A
Transcript

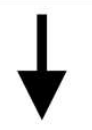

Fragment B
Fragment C

B)

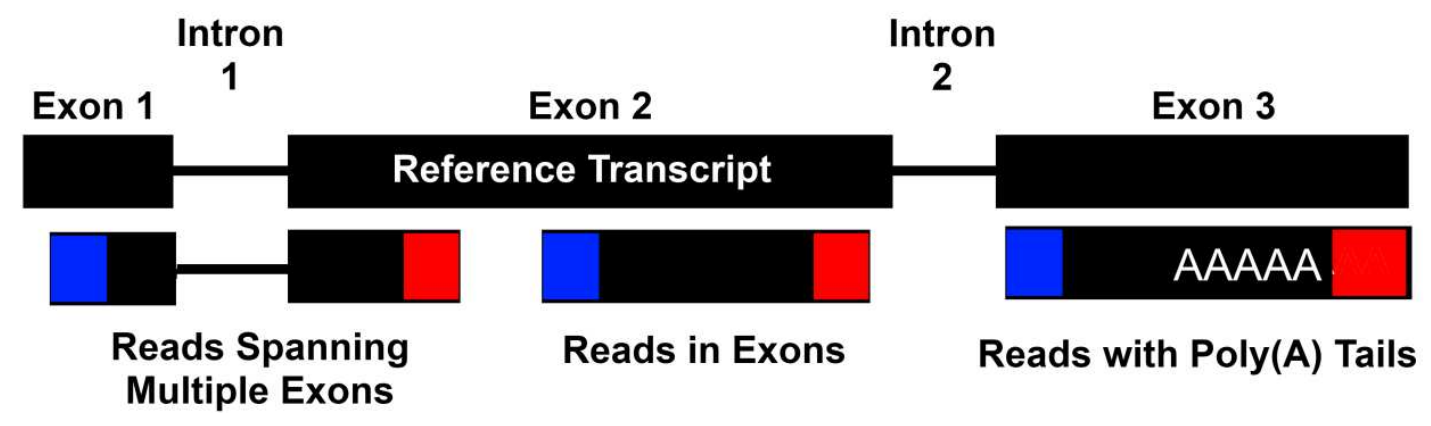

Figure 3: RNA-Seq Methodology A) Transcripts are fragmented into many pieces, with adaptors attached to both ends, adaptors shown in blue and red. B) Example of RNA-Seq read alignment to a reference genome after sequencing. Exons depicted are categorized into three major categories, shown at bottom. 
Using a reference genome allows for improved annotation of the transcripts, and comparison of expression levels between tissues (Wang et al. 2009). Additionally, RNA-Seq is capable of identifying transcripts with novel exons, unusual isoforms, and alternatively polyadenylated ends (Cui et al. 2010; Driver et al. 2012). This allows for a thorough survey of the RNA population, although PCR verification is required to confirm all novel discoveries. Only a few studies have used RNA-Seq for oocytes, embryos, and testis (Ameur et al. 2011; Esteve-Codina et al. 2011), but the manuscript presented in this thesis (Card and Anderson et al., 2013) is the first to report the spermatozoal transcript profile using RNA-Seq for any species.

\section{Hypotheses}

1. Full-length transcripts exist within the spermatozoal transcript profile.

2. If spermatozoal mRNA is functional after fertilization, then full-length transcripts will be found in the early embryo.

\section{Aims}

The primary aim of this study is to identify and validate full-length mRNA primarily from RNA-Sequencing of bovine spermatozoa. The secondary aim is to determine if full-length spermatozoal transcripts are delivered to the oocyte at fertlilization, allowing for future studies to track their inheritance from paternal sources to the embryo.

\section{References}

Ameur, A., A. Zaghlool, J. Halvardson, A. Wetterbom, U. Gyllensten, L. Cavelier, and L. Feuk. 2011. Total RNA sequencing reveals nascent transcription and widespread 
co-transcriptional splicing in the human brain. Nature structural \& molecular biology 18:1435-40.

Arangasamy, A., V. R. Kasimanickam, J. M. Dejarnette, and R. K. Kasimanickam. 2011. Association of CRISP2, CCT8, PEBP1 mRNA abundance in sperm and sire conception rate in Holstein bulls. Theriogenology 76:570-577.

Avendaño, C., A. Franchi, E. Jones, and S. Oehninger. 2009. Pregnancy-specific \{beta\}-1-glycoprotein 1 and human leukocyte antigen-E mRNA in human sperm: differential expression in fertile and infertile men and evidence of a possible functional role during early development. Human reproduction (Oxford, England) 24:270-7.

Bissonnette, N., J.-P. Lévesque-Sergerie, C. Thibault, and G. Boissonneault. 2009. Spermatozoal transcriptome profiling for bull sperm motility: a potential tool to evaluate semen quality. Reproduction (Cambridge, England) 138:65-80.

Boerke, a, S. J. Dieleman, and B. M. Gadella. 2007. A possible role for sperm RNA in early embryo development. Theriogenology 68 Suppl 1:S147-55.

Braun, R. E. 1998. Post-transcriptional control of gene expression during spermatogenesis. Seminars in cell \& developmental biology 9:483-9.

Braun, R. E. 2000. Temporal control of protein synthesis during spermatogenesis. International journal of andrology 23 Suppl 2:92-4.

Card, C., E. J. Anderson, S. Zamberlan, K.-B. E. Krieger, M. Kaproth, and B. L. Sartini. 2013. Cryopreserved Bovine Spermatozoal Transcript Profile as Revealed by High-Throughput Ribonucleic Acid Sequencing. Biology of Reproduction .

Carrell, D. T., and S. S. Hammoud. 2010. The human sperm epigenome and its potential role in embryonic development. Molecular human reproduction 16:37-47.

Chalmel, F., A. D. Rolland, C. Niederhauser-Wiederkehr, S. S. W. Chung, P. Demougin, A. Gattiker, J. Moore, et al. 2007. The conserved transcriptome in human and rodent male gametogenesis. Proceedings of the National Academy of Sciences of the United States of America 104:8346-51.

Chiriva-Internati, M., N. Gagliano, E. Donetti, F. Costa, F. Grizzi, B. Franceschini, E. Albani, et al. 2009. Sperm protein 17 is expressed in the sperm fibrous sheath. Journal of translational medicine 7:61.

Cui, P., Q. Lin, F. Ding, C. Xin, W. Gong, L. Zhang, J. Geng, et al. 2010. A comparison between ribo-minus RNA-sequencing and polyA-selected RNAsequencing. Genomics 96:259-65. 
Dadoune, J.-P., J.-P. Siffroi, and M.-F. Alfonsi. 2004. Transcription in haploid male germ cells. International Review Of Cytology 237:1-56.

Danckwardt, S., M. W. Hentze, and A. E. Kulozik. 2008. 3' end mRNA processing: molecular mechanisms and implications for health and disease. The EMBO journal 27:482-98.

Das, P. J., N. Paria, A. Gustafson-Seabury, M. Vishnoi, S. P. Chaki, C. C. Love, D. D. Varner, et al. 2010. Total RNA isolation from stallion sperm and testis biopsies. Theriogenology 74:1099-1106, 1106e1-2.

Donovan, P. J., and S. I. Reed. 2003. Germline Exclusion of Cks1 in the Mouse Reveals a Metaphase I Role for Cks Proteins in Male and Female Meiosis nd io sc ie $\mathrm{nc}$ ot fo $\mathrm{r} d$ is $\mathrm{t}$ rib ut $\mathrm{n}$. 275-276.

Driver, A. M., F. Penagaricano, W. Huang, K. R. Ahmad, K. S. Hackbart, M. C. Witlbank, and H. Khatib. 2012. RNA-Seq analysis uncovers transcriptomic variations between morphologically similar in vivo- and in vitro-derived bovine blastocysts. BMC genomics 13:118.

Eddy, E. M. 2002. Male germ cell gene expression. Recent progress in hormone research 57:103-28.

Ellis, P. J. I., Y. Yu, and S. Zhang. 2011. for offspring sex-specific antigens in sperm.

Esteve-Codina, A., R. Kofler, N. Palmieri, G. Bussotti, C. Notredame, and M. PerezEnciso. 2011. Exploring the gonad transcriptome of two extreme male pigs with RNAseq. BMC genomics 12:552.

Feugang, J. M., N. Rodriguez-Osorio, a Kaya, H. Wang, G. Page, G. C. Ostermeier, E. K. Topper, et al. 2010. Transcriptome analysis of bull spermatozoa: implications for male fertility. Reproductive biomedicine online 21:312-24.

Fischer, B. E., E. Wasbrough, L. a Meadows, O. Randlet, S. Dorus, T. L. Karr, and S. Russell. 2012. Conserved properties of Drosophila and human spermatozoal mRNA repertoires. Proceedings. Biological sciences / The Royal Society 279:2636-44.

Foote, R. H. 2003. Fertility estimation: a review of past experience and future prospects. Animal reproduction science 75:119-39.

Gallie, D. R. 1991. The cap and poly(A) tail function synergistically to regulate mRNA translational efficiency. Genes \& Development 5:2108-2116.

Ganguly, I., G. K. Gaur, S. Kumar, D. K. Mandal, M. Kumar, U. Singh, S. Kumar, et al. 2012. Differential expression of protamine 1 and 2 genes in mature spermatozoa of 
normal and motility impaired semen producing crossbred Frieswal (HF×Sahiwal) bulls. Research in veterinary science 1.

García-Herrero, S., M. Meseguer, J. A. Martínez-Conejero, J. Remohí, A. Pellicer, and N. Garrido. 2010. The transcriptome of spermatozoa used in homologous intrauterine insemination varies considerably between samples that achieve pregnancy and those that do not. Fertility and sterility 94:1360-73.

Gilbert, I., N. Bissonnette, G. Boissonneault, M. Vallée, and C. Robert. 2007. A molecular analysis of the population of mRNA in bovine spermatozoa. Reproduction (Cambridge, England) 133:1073-86.

Gur, Y., and H. Breitbart. 2008. Protein synthesis in sperm: dialog between mitochondria and cytoplasm. Molecular and cellular endocrinology 282:45-55.

Hamatani, T. 2012. Human spermatozoal RNAs. Fertility and sterility 97:275-81.

Hayward, A., and J. F. Gillooly. 2011. The cost of sex: quantifying energetic investment in gamete production by males and females. PloS one 6:e16557.

Hecht, N., R. Behr, A. Hild, M. Bergmann, W. Weidner, and K. Steger. 2009. The common marmoset (Callithrix jacchus) as a model for histone and protamine expression during human spermatogenesis. Human reproduction (Oxford, England) 24:536-45.

Hecht, N., M. C. O. Cavalcanti, P. Nayudu, R. Behr, M. Reichenbach, W. Weidner, and K. Steger. 2010. Protamine-1 represents a sperm specific gene transcript: a study in Callithrix jacchus and Bos taurus. Andrologia 43:1-7.

Holstein, A. F., E. C. Roosen-Runge, and C. Schirren. 1988. Illustrated pathology of human spermatogenesis. Grosse, Berlin.

Holstein, A.-F., W. Schulze, and M. Davidoff. 2003. Understanding spermatogenesis is a prerequisite for treatment. Reproductive biology and endocrinology $\square: \mathrm{RB} \& E$ $1: 107$.

Iguchi, N., J. W. Tobias, and N. B. Hecht. 2006. Expression profiling reveals meiotic male germ cell mRNAs that are translationally up- and down-regulated. Proceedings of the National Academy of Sciences of the United States of America 103:7712-7.

Isken, O., and L. E. Maquat. 2007. Quality control of eukaryotic mRNA: safeguarding cells from abnormal mRNA function. Genes \& development 21:1833-56.

Jenkins, T. G., and D. T. Carrell. 2012. The sperm epigenome and potential implications for the developing embryo. Reproduction (Cambridge, England) 143:727-34. 
Jodar, M., S. Kalko, J. Castillo, J. L. Ballescà, and R. Oliva. 2012. Differential RNAs in the sperm cells of asthenozoospermic patients. Human reproduction (Oxford, England) 27:1431-8.

Johnson, G. D., C. Lalancette, A. K. Linnemann, F. Leduc, G. Boissonneault, and S. a Krawetz. 2011a. The sperm nucleus: chromatin, RNA, and the nuclear matrix. Reproduction (Cambridge, England) 141:21-36.

Johnson, G. D., E. Sendler, C. Lalancette, R. Hauser, M. P. Diamond, and S. a Krawetz. 2011b. Cleavage of rRNA ensures translational cessation in sperm at fertilization. Molecular human reproduction 17:721-6.

Kempisty, B., P. Antosik, D. Bukowska, M. Jackowska, M. Lianeri, J. M. J. M. Jaśkowski, P. P. Jagodzi'nski, et al. 2008a. Analysis of selected transcript levels in porcine spermatozoa, oocytes, zygotes and two-cell stage embryos. Reproduction, fertility, and development 20:513-8.

Kempisty, B., P. Antosik, D. Bukowska, M. Jackowska, M. Lianeri, J. M. Jaśkowski, and P. P. Jagodzi'nski. 2008b. Analysis of selected transcript levels in porcine spermatozoa, oocytes, zygotes and two-cell stage embryos. Reproduction, Fertility and Development 20:513-518.

Killian, G. 2012. Fertility-associated proteins in male and female reproductive fluids of cattle 703-712.

Kleene, K. C. 2005. Sexual selection, genetic conflict, selfish genes, and the atypical patterns of gene expression in spermatogenic cells. Developmental biology 277:16-26.

Kocabas, A. M., J. Crosby, P. J. Ross, H. H. Otu, Z. Beyhan, H. Can, W.-L. Tam, et al. 2006. The transcriptome of human oocytes. Proceedings of the National Academy of Sciences of the United States of America 103:14027-32.

Kono, T., Y. Obata, Q. Wu, and K. Niwa. 2004. Birth of parthenogenetic mice that can develop to adulthood 428:3-7.

Lalancette, C., and D. Miller. 2008. Paternal contributions: new functional insights for spermatozoal RNA. Journal of cellular ... 104:1570-1579.

Lalancette, C., C. Thibault, I. Bachand, N. Caron, and N. Bissonnette. 2008. Transcriptome analysis of bull semen with extreme nonreturn rate: use of suppressionsubtractive hybridization to identify functional markers for fertility. Biology of reproduction 78:618-35.

Lee, C., and N. Kikyo. 2012. Strategies to identify long noncoding RNAs involved in gene regulation. Cell \& bioscience 2:37. 
Liu, W., R. T. K. Pang, P. C. N. Chiu, B. P. C. Wong, K. Lao, and K. Lee. 2012. Sperm-borne microRNA-34c is required for the first cleavage division in mouse. PNAS 109:490-494.

Mali, P., A. Kaipia, M. Kangasniemi, J. Toppari, M. Sandberg, N. B. Hecht, and M. Parvinen. 1989. Stage-specific expression of nucleoprotein mRNAs during rat and mouse spermiogenesis. Reproduction, Fertility and Development 1:369-382.

Mamo, S., J. P. Mehta, P. McGettigan, T. Fair, T. E. Spencer, F. W. Bazer, and P. Lonergan. 2011. RNA sequencing reveals novel gene clusters in bovine conceptuses associated with maternal recognition of pregnancy and implantation. Biology of reproduction 85:1143-51.

Mao, B., W. Wu, G. Davidson, J. Marhold, M. Li, B. M. Mechler, H. Delius, et al. 2002. Kremen proteins are Dickkopf receptors that regulate Wnt/beta-catenin signalling. Nature 417:664-7.

Marshall Graves, J. a. 2000. Human Y chromosome, sex determination, and spermatogenesis- a feminist view. Biology of reproduction 63:667-76.

Memili, E., and N. L. First. 2000. Zygotic and embryonic gene expression in cow: a review of timing and mechanisms of early gene expression as compared with other species. Zygote (Cambridge, England) 8:87-96.

Miller, D., and G. C. Ostermeier. 2006. Spermatozoal RNA: Why is it there and what does it do? Gynécologie, obstétrique \& fertilité 34:840-6.

Miller, D., G. C. Ostermeier, and S. a Krawetz. 2005. The controversy, potential and roles of spermatozoal RNA. Trends in molecular medicine 11:156-63.

Misirlioglu, M., G. P. Page, H. Sagirkaya, a Kaya, J. J. Parrish, N. L. First, and E. Memili. 2006. Dynamics of global transcriptome in bovine matured oocytes and preimplantation embryos. Proceedings of the National Academy of Sciences of the United States of America 103:18905-10.

Ostermeier, G. C., D. J. Dix, D. Miller, P. Khatri, and S. A. Krawetz. 2002.

Mechanisms of disease Spermatozoal RNA profiles of normal fertile men 772-777.

Ostermeier, G. C., R. J. Goodrich, J. S. Moldenhauer, M. P. Diamond, and S. a Krawetz. 2005. A suite of novel human spermatozoal RNAs. Journal of andrology 26:70-4.

P.L.Senger. 2005. Pathways to Pregnancy and Parturition (2nd ed., pp. 196-197). Current Conceptions, Inc., Pullman, WA. 
Park, Y.-J., W.-S. Kwon, S.-A. Oh, and M.-G. Pang. 2012. Fertility-related proteomic profiling bull spermatozoa separated by percoll. Journal of proteome research 11:4162-8.

Parker, R., and U. Sheth. 2007. P bodies and the control of mRNA translation and degradation. Molecular cell 25:635-46.

Pessot, C. A., M. Brito, J. Figueroa, I. I. Concha, A. Yañez, and L. O. Burzio. 1989. Presence of RNA in the sperm nucleus. Biochemical and Biophysical Research Communications 158:272-278.

Petersen, C., and O. Soder. 2006. The sertoli cell--a hormonal target and "super" nurse for germ cells that determines testicular size. Hormone research 66:153-61.

Potireddy, S., R. Vassena, B. G. Patel, and K. E. Latham. 2006. Analysis of polysomal mRNA populations of mouse oocytes and zygotes: dynamic changes in maternal mRNA utilization and function. Developmental biology 298:155-66.

Rassoulzadegan, M., V. Grandjean, P. Gounon, S. Vincent, I. Gillot, and F. Cuzin. 2006. RNA-mediated non-mendelian inheritance of an epigenetic change in the mouse. Nature 441:469-74.

Reik, W., and J. Walter. 2001. Genomic imprinting: parental influence on the genome. Nature reviews. Genetics 2:21-32.

Rogers, N. T., E. Hobson, S. Pickering, F. a Lai, P. Braude, and K. Swann. 2004. Phospholipase Czeta causes $\mathrm{Ca} 2+$ oscillations and parthenogenetic activation of human oocytes. Reproduction (Cambridge, England) 128:697-702.

Saunders, C. M., M. G. Larman, J. Parrington, L. J. Cox, J. Royse, L. M. Blayney, K. Swann, et al. 2002. PLC zeta: a sperm-specific trigger of $\mathrm{Ca}(2+)$ oscillations in eggs and embryo development. Development (Cambridge, England) 129:3533-44.

Schlecht, U., and M. Primig. 2003. Review Mining meiosis and gametogenesis with DNA microarrays 447-456.

Sekiguchi, T., H. Iida, J. Fukumura, and T. Nishimoto. 2004. Human DDX3Y, the Yencoded isoform of RNA helicase DDX3, rescues a hamster temperature-sensitive ET24 mutant cell line with a DDX3X mutation. Experimental cell research 300:21322.

Session, D. R., G. S. Lee, and D. J. Wolgemuth. 2001. Characterization of D1Pas1, a mouse autosomal homologue of the human AZFa region DBY, as a nuclear protein in spermatogenic cells. Fertility and sterility 76:804-11. 
Smirnova, N. a, P. J. Romanienko, P. P. Khil, and R. D. Camerini-Otero. 2006. Gene expression profiles of Spo11-/- mouse testes with spermatocytes arrested in meiotic prophase I. Reproduction (Cambridge, England) 132:67-77.

Suri, A. 2004. Sperm specific proteins-potential candidate molecules for fertility control. Reproductive biology and endocrinology $\square:$ RB\&E 2:10.

Sutovsky, P. 2003. Ubiquitin-dependent proteolysis in mammalian spermatogenesis, fertilization, and sperm quality control: killing three birds with one stone. Microscopy research and technique 61:88-102.

Swann, K., C. M. Saunders, N. T. Rogers, and F. a Lai. 2006. PLCzeta(zeta): a sperm protein that triggers $\mathrm{Ca} 2+$ oscillations and egg activation in mammals. Seminars in cell \& developmental biology 17:264-73.

Thelie, A., P. Papillier, C. Perreau, S. Uzbekova, C. Hennequet-Antier, and R. Dalbies-Tran. 2009. Regulation of bovine oocyte-specific transcripts during in vitro oocyte maturation and after maternal-embryonic transition analyzed using a transcriptomic approach. Molecular reproduction and development 76:773-82.

Thompson, W. E., J. Ramalho-Santos, and P. Sutovsky. 2003. Ubiquitination of prohibitin in mammalian sperm mitochondria: possible roles in the regulation of mitochondrial inheritance and sperm quality control. Biology of reproduction 69:25460 .

Vigneault, C., C. Gravel, M. Vallée, S. McGraw, and M.-A. Sirard. 2009. Unveiling the bovine embryo transcriptome during the maternal-to-embryonic transition. Reproduction (Cambridge, England) 137:245-57.

Vong, Q. P., Y. Li, Y.-F. C. Lau, M. Dym, O. M. Rennert, and W.-Y. Chan. 2006. Structural characterization and expression studies of Dby and its homologs in the mouse. Journal of andrology 27:653-61.

Wang, Z., M. Gerstein, and M. Snyder. 2009. RNA-Seq: a revolutionary tool for transcriptomics. Nature reviews. Genetics 10:57-63.

Wykes, S. M., D. W. Visscher, and S. a Krawetz. 1997. Haploid transcripts persist in mature human spermatozoa. Molecular human reproduction 3:15-9.

Yamagata, K., T. Nakanishi, M. Ikawa, R. Yamaguchi, S. B. Moss, and M. Okabe. 2002. Sperm from the Calmegin-Deficient Mouse Have Normal Abilities for Binding and Fusion to the Egg Plasma Membrane. Developmental Biology 250:348-357.

Yao, C., Z. Wang, Y. Zhou, W. Xu, Q. Li, D. Ma, L. Wang, et al. 2010a. A study of Y chromosome gene mRNA in human ejaculated spermatozoa. Molecular reproduction and development 77:158-66. 
Yao, C.-J. C. J., W.-J. W. J. Xu, X. L. X.-L. Gong, Y. Zhou, Z. Q. Z.-Q. Z. Q. Yan, Z.-J. Z. J. Zhu, Z. X. Z.-X. Wang, et al. 2010b. The role of Dby mRNA in early development of male mouse zygotes. Asian Journal of Andrology 12:567-577.

Zhang, Y., L. Zhong, B. Xu, Y. Yang, R. Ban, J. Zhu, H. J. Cooke, et al. 2012. SpermatogenesisOnline 1.0: a resource for spermatogenesis based on manual literature curation and genome-wide data mining. Nucleic Acids Research 1-8.

Ziyyat, a, B. Lassalle, J. Testart, P. Briot, E. Amar, C. Finaz, and a Lefèvre. 1999. Flow cytometry isolation and reverse transcriptase-polymerase chain reaction characterization of human round spermatids in infertile patients. Human reproduction (Oxford, England) 14:379-87. 


\section{CHAPTER 2: BIOLOGY OF REPRODUCTION MANUSCRIPT}

This manuscript was co-authored with Christopher Card and published in January 2013 in the journal "Biology of Reproduction." Liz was a co-first author on this manuscript with a primary focus on identification of full-length transcripts in the bovine sperm transcript profile. She was also responsible for all gene ontology analysis. Liz was responsible for tables 3, 5, 6, and figure 3, and collaborated with Chris Card on figures 1, 4, and tables 1, 2, and 4. The writing and editing of the manuscript was shared equally between Chris and Liz.

\section{Cryopreserved Bovine Spermatozoal Transcript Profile as Revealed by RNA-Seq}

Card $\mathrm{C}^{1^{*}}$, Anderson $\mathrm{EJ}^{{ }^{*}}{ }^{*}$, Zamberlan $\mathrm{S}^{1}$, Krieger $\mathrm{KE}^{2}$, Kaproth $\mathrm{M}^{2}$, Sartini $\mathrm{BL}^{1,3}$

*these authors contributed equally to the writing of this manuscript

${ }^{1}$ Department of Fisheries, Animal and Veterinary Science, University of Rhode Island, Kingston, Rhode Island 02881. ${ }^{2}$ Genex Cooperative Inc., Shawano, WI 54166.

${ }^{3}$ Corresponding author: BL Sartini, 179 Center for Biotechnology and Life Sciences, 120 Flagg Road, University of Rhode Island, Kingston, RI 02881, Phone: 401-8742667, FAX: 401-874-7575, Email: blsartini@uri.edu.

Short Title: Bovine Spermatozoal Transcript Profile Summary Sentence: The bovine spermatozoal transcript profile contains degraded and full-length mRNAs.

\section{Key Words: RNA-Seq, spermatozoa, bovine, mRNA}

Abbreviations: $\mathrm{mRNA}=$ messenger RNA; FPKM $=$ Fragments Per Kilobase of transcript per Million mapped reads; RNA-Seq = ribonucleic acid sequencing; rRNA = ribosomal ribonucleic acid $\mathrm{CR}=$ conception rate; $\mathrm{qPCR}=$ quantitative polymerase chain reaction; $\mathrm{UTR}=$ untranslated region; $\mathrm{MF}=$ Molecular Function; $\mathrm{BP}=$ Biological Process; $\mathrm{CC}=$ Cellular Component

Grant Support: This project was supported by Genex Cooperative, Inc. and by the Agriculture and Food Research Initiative Competitive Grant no. 2011-67016-20073 
from the USDA National Institute of Food and Agriculture to Becky L. Sartini. This research is based in part upon work conducted using the Rhode Island Genomics and Sequencing Center that is supported in part by the National Science Foundation under EPSCoR Grants Nos. 0554548 \& EPS-1004057. 


\section{$\underline{\text { Abstract }}$}

Ejaculated bovine spermatozoa retain a pool of RNAs that may have a function in early embryogenesis and be used as predictors of male fertility. The bovine spermatozoal transcript profile remains incomplete because previous studies have relied on hybridization-based techniques, which evaluate a limited pool of transcripts and cannot identify full-length transcripts. The goal of this study was to sequence the complete cryopreserved bovine spermatozoal transcript profile using Illumina RNASeq. Spermatozoal RNA was pooled from nine bulls with conception rate (CR) scores ranging from -2.9 to 3.5 and confirmed to exclude genomic DNA and somatic cell mRNA. After selective amplification of polyA ${ }^{+}$RNA and high-throughput sequencing, 6,166 transcripts were identified via alignment to the bovine genome (UMD 3.1/bosTau6). RNA-Seq transcript levels $(n=9)$ were highly correlated with qPCR copy number $\left(r^{2}=0.9747\right)$. The bovine spermatozoal transcript profile is a heterogeneous population of degraded and full-length predominantly nuclear-encoded mRNAs. Highly abundant spermatozoal transcripts included PRM1, HMGB4 and mitochondrial-encoded transcripts. Full-length transcripts comprised $66 \%$ of the top 368 transcripts (FPKM>100) and the full-length amplification or 5' and 3' exons were confirmed for some transcripts. In addition to the identification of transcripts not previously reported in spermatozoa, several known spermatozoal transcripts from various species were also found. Gene ontology analysis of the top 368 spermatozoal transcripts revealed that translation was the most predominant biological process represented. This is the first report of the spermatozoal transcript profile in any species 
using high-throughput sequencing, supporting the presence of mRNA in spermatozoa for further functional and fertility studies.

\section{$\underline{\text { Introduction }}$}

In addition to delivering the paternal genome to the oocyte at fertilization, ejaculated spermatozoa retain a pool of RNAs, containing mRNAs, rRNAs and short non-coding RNAs [1-4]. Spermatozoal antisense RNAs epigenetically regulate early embryonic development and have a structural role in maintaining histone-bound spermatozoa chromosomal regions [3-6]. Although the complete spermatozoal mRNA profile is not known, spermatozoa contain at least 3,000-7,000 mRNAs with predominantly short fragments, probably indicative of a predominance of degraded RNA [7-9]. Individual spermatozoal transcripts that have been identified include mRNAs for ribosomal proteins, mitochondrial proteins, protamines, and proteins involved in signal transduction and cell proliferation [7-12]. The hypothesized function of the spermatozoal transcripts in transcriptionally-silent spermatozoa is currently unknown although spermatozoa-derived mRNAs, including PRM1, PRM2, $P S G-1, C L U, H L A-E, D B Y$ and $P L C Z 1$, can be detected in embryos post-fertilization suggesting a role for spermatozoal mRNAs in the zygote [13-18]. However, only translation of $P L C Z 1$ has been demonstrated in embryos and many of these spermatozoal transcripts are rapidly degraded in the embryo rendering them nonfunctional [15-18]. Some spermatozoal transcripts may be translated in the mitochondria during capacitation [19]. Additionally, the diagnostic potential of the total spermatozoal RNA population as a snapshot of spermatogenic gene expression is 
emerging. Individual transcripts are stably regulated within and between individual males and perturbation of the ubiquitin-proteosome pathway during spermatogenesis can be detected in spermatozoal RNA making this a promising area for male fertility assay development [20-23].

The bovine spermatozoal transcript profile remains incomplete because previous studies have relied on hybridization-based techniques, which evaluate a limited pool of transcripts and do not provide information about full-length transcripts $[7,9,10,24$, 25]. In contrast, RNA-Sequencing (RNA-Seq), based on high-throughput sequencing technology, is revolutionizing our understanding of transcriptomics by enabling sequencing of complete transcript profiles, including full-length mRNAs and identifying novel splicing junctions and exons [26, 27]. Also unique to this direct sequencing, absolute quantification of a broad range of expression levels across transcripts can be obtained. High-throughput sequencing of the total RNA in human spermatozoa has focused on rRNA and small non-coding RNA populations but the complete mRNA profile has not been reported $[2,4]$.

We hypothesize that the transcript profile of cryopreserved bovine spermatozoa can be directly sequenced using RNA-Seq. Over 6000 spermatozoal transcripts were sequenced with this approach and a heterogeneous population of degraded and fulllength mRNAs was identified. Previously reported spermatozoal transcripts were confirmed while a number of transcripts not previously found in spermatozoa of any species have also been identified including $H M G B 4, G T S F 1$, and $C K S 2$. This is the first study to date to utilize RNA-Seq to sequence the spermatozoal mRNA population and report full-length transcripts for any species. 


\section{$\underline{\text { Materials and Methods }}$}

\section{$\underline{\text { Spermatozoa Samples }}$}

Cryopreserved spermatozoa from Holstein bulls with conception rate (CR) scores ranging from -2.9 to 3.5 were obtained from Genex Cooperative Inc. (Shawano, WI). Spermatozoa from nine bulls ( -2.9 to $3.5 \mathrm{CR}$ ) was used to generate the amplified cDNA pool for RNA-Seq, for qPCR validation and PCR amplification of the 5' and 3' exons. Spermatozoal RNA from nine additional bulls was also converted to cDNA and amplified for PCR amplification of transcripts in individual bulls. Finally, a separate pool of spermatozoa RNA from three different bulls was not cDNA amplified and used for PCR amplification of full-length transcripts. Two straws per bull were thawed in a $37^{\circ} \mathrm{C}$ water bath for one minute and then washed twice in $4 \mathrm{~mL}$ PBS (10 minutes at $600 x \mathrm{~g}$ ). The resulting spermatozoa pellet was subsequently used for RNA isolation.

\section{$\underline{\text { RNA Isolation }}$}

Bull testis RNA was isolated with TRIZol (Sigma-Aldrich; St. Louis, MO). Spermatozoal RNA isolation was conducted using the TRIzol method reported by Das et al., 2010 [8] with slight modifications. Spermatozoa pellets were added to $1 \mathrm{~mL}$ TRIzol supplemented with glycogen $(15 \mu \mathrm{g} / \mathrm{ml})$. Samples were then lysed through a 26 gauge needle 20 times and incubated for 30 minutes at room temperature. Chloroform was added to the samples followed by a 10 minute incubation at room temperature. For phase separation, samples were centrifuged at $12000 \times g$ for 15 minutes at $4^{\circ} \mathrm{C}$. The top layer (RNA) was removed and added to $500 \mu \mathrm{L}$ ice cold 
isopropanol and incubated on ice for 10 minutes followed by centrifugation $12000 \times \mathrm{g}$ for 10 minutes at $4^{\circ} \mathrm{C}$ to precipitate the RNA. RNA pellets were washed with $1 \mathrm{~mL}$ $75 \%$ ethanol and air dried, followed by resuspension in nuclease free water. RNA samples were treated with DNAse using the RNA Cleanup protocol from the RNeasy Mini Kit (Qiagen, Valencia, CA). RNA concentrations were measured using the NanoDrop UV/Vis Spectrometer (Thermo Scientific; Wilmington, DE) and RNA samples stored at $-80^{\circ} \mathrm{C}$ until used for subsequent analysis.

\section{Double-Stranded cDNA (ds-cDNA) Synthesis and Amplification}

Due to low RNA yields typical of spermatozoal RNA isolations, the spermatozoal RNA was converted to ds-cDNA and amplified for RNA-Seq analysis and qPCR validation (SMARTer Pico PCR cDNA Synthesis Kit; Clontech, Mountain View, CA). This method maintains gene representation in the original RNA pool. Due to the varying amounts of RNA extracted from each bull, the amount of RNA added for amplification was normalized to the sample with the lowest concentration to ensure equal representation of the nine bulls in the pooled sample. The amplification protocol enriches the full-length mRNA population with a modified oligo(dT) primer. Amplification cycles were optimized to 26 cycles following the protocol instructions to insure amplification the linear phase. Following ds-cDNA conversion and amplification, $5 \mu \mathrm{g}$ of spermatozoal ds-cDNA was submitted for Illumina sequencing and the remaining spermatozoal ds-cDNA was used for qPCR validation postsequencing. To verify the quality of ds-cDNA, an aliquot of the sample was run on the Agilent Bioanalyzer 2100 (Agilent Technologies; Santa Clara, CA). 


\section{$\underline{\text { PCR }}$}

PCR reactions validated the lack of genomic DNA and somatic cell RNA in the spermatozoal RNA as well as full-length and 5' and 3' exon amplification in the spermatozoal transcript profile. All PCR reactions were conducted with intron spanning primers (Table 1). Most PCR reactions were run with spermatozoal dscDNA except for the spermatozoal ds-cDNA sample that was spiked with genomic DNA $(1 \mu \mathrm{g})$ isolated from the bull testis tissue (Lane G in Figure 1; Qiagen DNA Blood and Tissue kit; Valencia, CA). For amplification of full-length transcripts from unamplified ds-cDNA, spermatozoal RNA $(1 \mu \mathrm{g})$ was reverse transcribed using the Superscript III Reverse Transcriptase Kit (Invitrogen, Carlsbad, CA). $1 \mu$ L OligoDT primers (IDT, Coralville, IA), $1 \mu \mathrm{L}$ dNTPs, $2 \mu \mathrm{g}$ mRNA from the isolation and $1 \mu \mathrm{L}$ water are combined, incubated at $65^{\circ} \mathrm{C}$ for 5 minutes, then chilled on ice for a minute. Following the chill, $4 \mu \mathrm{L}$ 5X First Strand Buffer, $1 \mu \mathrm{L} 0.1 \mathrm{mM}$ DTT, $1 \mu \mathrm{L}$ RNaseOut, and $1 \mu \mathrm{L}$ Superscript III were added to the tube, incubated at $50^{\circ} \mathrm{C}$ for 45 minutes, then $70^{\circ} \mathrm{C}$ for 15 minutes. Then RNase $\mathrm{H}$ was added and the sample was incubated at $37^{\mathrm{O}} \mathrm{C}$ for 20 minutes. This procedure converts the mRNA to cDNA for use in PCR amplification. For all primer pairs, cDNA was added to a PCR reaction mixture containing $1 \mathrm{X}$ reaction buffer, $1.5 \mathrm{mM} \mathrm{MgCl}_{2}, 10 \mathrm{mM}$ dNTPs, $2.5 \mu \mathrm{mol}$ forward and reverse primers and 2.5 U Taq polymerase (NEB; Ipswich, MA) and run with standard PCR conditions $\left(94^{\circ} \mathrm{C}\right.$ for $5 \mathrm{~min}, 35$ cycles of $94^{\circ} \mathrm{C}$ for $\left.30 \mathrm{sec}\right)$, primer dependent annealing temperature for $30 \mathrm{sec}$ then $72^{\circ} \mathrm{C}$ for $2 \mathrm{~min}$ followed by a final extension at $72^{\circ} \mathrm{C}$ for $\left.10 \mathrm{~min}\right)$. Negative controls containing no template cDNA and no enzyme 
were run in parallel to ensure gene specific amplification. The PCR products were separated by $2.0 \%$ agarose gel electrophoresis then gel purified (Qiagen Gel Extraction kit; Valencia, CA) and both strands sequenced (URI Genomics Center, Kingston, RI). Amplicon sequence identity was confirmed with NCBI BLAST.

\section{$\underline{\text { RNA-Seq and Analysis }}$}

Paired-end $100 \mathrm{bp}$ reads from spermatozoal ds-cDNA were generated using the Illumina HiSeq 2000 (Otogenetics; Norcross, GA). Sequence analysis was conducted with Galaxy [28-30]. Reads were converted with FASTQ groomer and then aligned to the bovine genome (Btau6/UMD_3.1) using Tophat [31]. Trimming the adapter AGATCGGAAGAGC removed 14.29\% (2,659,330 reads) from file 1 and 1.14\% (211,176 reads) from file 2 . Adaptor only reads, short sequence reads (15 nt minimum) and reads with unknown $\mathrm{N}$ bases were discarded during adapter trimming. Concatamers formed from amplification of the SMARTer II A Oligonucleotide (AAGCAGTGGTATCAACGCAGAGTAA) were found in 41.48\% (7,702,931 reads) for file 1 and $47.17 \%(8,760,365$ reads) for file 2 and were removed prior to further analysis. Alignment to the reference genome (UMD 3.1/bosTau6) was conducted using Tophat, which uses Bowtie for alignment [32]. A maximum of two mismatches were allowed during alignment. RSeQC was used to generate read and post-alignment summary statistics [33]. Levels of individual transcripts are expressed in fragments per kilobase of exon per million fragments mapped (FPKM) and were obtained using Cufflinks [30]. Quantification of full-length transcripts was conducted by manually visualizing the read mapping for individual transcripts to the bovine genome (UMD 
3.1/bosTau6) in the UCSC Genome Browser (http://genome.ucsc.edu/). Reads were archived in the NCBI SRA055325 (http://www.ncbi.nlm.nih.gov/sra).

\section{qPCR}

Quantitative PCR was used to validate RNA-Seq expression levels of the cryopreserved spermatozoal ds-cDNA. Nine transcripts were chosen that represented a range of FPKM values $(9.41$ to 20,667). A standard curve was generated by diluting DNA for each transcript into 7 concentrations ranging from $1 \times 10^{9}$ copies to $1 \times 10^{3}$ copies/ul. qPCR was performed with spermatozoal ds-cDNA and standard curves using the Brilliant II SYBR Green QPCR Master Mix Kit (Stratagene; Santa Clara, CA). All qPCR samples included negative template controls and were run in duplicate on the Stratagene Mx3005 instrument at the Genome Sequencing Center at the University of Rhode Island. Amplicon sequence identity was confirmed with NCBI BLAST.

\section{Gene Ontology Analysis}

Gene ontology analysis was conducted with the DAVID Bioinformatic Database (http://david.abcc.ncifcrf.gov/) using the three Gene Ontology Term categories: Biological Process, Molecular Function, and Cellular Component. Transcripts were analyzed in two different populations: FPKM $>0$ and FPKM $>100$. 


\section{$\underline{\text { Results }}$}

\section{Bovine spermatozoal RNA purity}

Using the Trizol method, the total amount of RNA isolated from two spermatozoa straws from an individual bull resulted in an average of $31 \mathrm{fg}$ RNA per spermatozoa. Bioanalyzer analysis of the spermatozoa RNA population shows a peak of smaller RNAs and a lack of $18 \mathrm{~S}$ and $28 \mathrm{~S}$ ribosomal RNA peaks present in testis RNA (Figure 1A). The spermatozoal RNA was free of leukocytes, testicular germ cells and epithelial cells as demonstrated by the lack of $C-K I T, C D 45$, and $C D H 1$ amplification respectively (Figure 1B). Genomic DNA was also not detected in the isolated bovine spermatozoal RNA compared to a sample spiked with genomic DNA (Figure 1C).

\section{$\underline{\text { Illumina Sequencing }}$}

High-throughput sequencing of the bovine spermatozoal RNA resulted in $18,570,350$ x 2 paired-end 100-bp reads. After removal of concatamers, a total of $2,538,688$ reads $(14.25 \%)$ of the total population mapped to the bovine genome with $79.84 \%$ of the aligned reads being uniquely mapped to a single transcript. Reads aligned specifically to coding exons (324,600 reads), 5'UTRs (39,758 reads), 3'UTRs (40,057 reads), and 2,274 reads contained poly(A) sequences. Exon-exon junctions $(157,717$ reads over 17,285 junctions $)$ were covered and 100,929 of those reads (64.21\%) mapped to 9,003 annotated junctions while 56,248 (35.79\%) reads mapped to 8,282 novel/partial junctions. All junctions were supported by at least two reads. Also, 144,432 intronic reads were found, several of which may represent novel exons. 


\section{Cryopreserved Bovine Spermatozoal Transcript Profile}

A total of 6,166 transcripts were identified in spermatozoal RNA with a FPKM $>0$ (Fragments Per Kilobase of transcript per Million reads mapped). The qPCR expression values showed a high correlation with FPKM values $\left(r^{2}=0.9747\right.$; Figure 2). The bovine spermatozoal transcript profile contains predominantly nuclear-encoded mRNAs including 33 mitochondrial-encoded rRNAs and mRNAs representing $0.5 \%$ of the spermatozoal transcript profile. Many of these mitochondrial transcripts were highly abundant, with 32 of 33 in the top 100 transcripts ranked by FPKM. The top 10 transcripts based on FPKM, excluding the mitochondrial RNAs, are listed in Table 2.

A heterogeneous population of degraded and full-length transcripts was identified. Degraded transcripts (lacking reads mapping to all exons) were more prevalent below FPKM $=100$. Due to this observation, all transcripts with FPKM>100 (368 transcripts) were analyzed individually for reads mapping to each exon to be considered a full-length transcript. In the FPKM>100 population, $66 \%$ of the transcripts had reads aligned to all exons, including amplification of the 5' and 3' exons, potentially indicating the presence of full-length transcripts in the spermatozoal RNA population (Supplementary Table 1). Some of these full-length transcripts also included intronic reads that potentially represent novel exons. Retention of the 5'and 3' exons for PLCZ1, CRISP2, and GSTM3 were validated while many transcripts with FPKM $<100$ did not retain the 5' exon, including $D D X 3 Y$ (Figure $3 \mathrm{~A}$ ). The presence of full-length transcripts for GSTM3 and GSTF1 was confirmed by PCR amplification of the intact transcript from the first to last exon in unamplified cDNA (Figure 3B). A 
preliminary survey of the bovine spermatozoal transcript profile for previously reported spermatozoal RNA candidates identified several transcripts in bovine, human, porcine and mouse (Table 3). These transcripts represented a wide range of FPKM levels, and nine of these transcripts retained the 5' and 3' exons, potentially indicating that these transcripts are also full-length (Table 3).

A number of additional full-length bovine spermatozoal transcripts have not been previously reported in spermatozoal RNA, including HMGB4, PSMA6, GTSF 1, and CKS2 (Table 4). Variation in the amount of select transcripts among bulls was demonstrated in an independent population of nine bulls (not included in RNA-Seq population; Figure 4).

\section{$\underline{\text { Gene Ontology Analysis }}$}

For gene ontology analysis, spermatozoal transcripts were analyzed in two different populations: FPKM >0 $(n=6,166)$ and FPKM $>100(n=368)$. Transcripts were classified into the following ontological categories: Biological Processes (BP), Cellular Components (CC), and Molecular Functions (MF) and the top ten categories for each are shown in Table 5. In the total spermatozoal transcript population (FPKM>0), $367 \mathrm{BP}, 142 \mathrm{CC}$, and $161 \mathrm{MF}$ categories were found. It is important to note that an individual transcript can be represented in multiple categories. The top BP categories included translation (GO: 0006412; 264 transcripts) and proteolysis (GO: 0051603; 241 transcripts). Because a majority of full-length transcripts were found in the FPKM>100 population, we also analyzed this population separately. Translation remained the most predominant BP represented within this population (55 
transcripts). Within the translation category, 38 of the 55 transcripts encoded for ribosomal proteins and the remaining transcripts included eukaryotic translation initiation factors (EIFI and EIF5), eukaryotic translation elongation factors (EEFIAI and $E E F(\gamma)$ ), polyubiquitin and unknown transcripts. Twenty-four of these ribosomal transcripts were full-length (all exons mapped), as well as EEF1A1, EEF1 $\gamma$ and polyubiquitin.

\section{$\underline{\text { Discussion }}$}

Here, we report the first cryopreserved bovine spermatozoal transcript profile using RNA-Seq, which includes degraded and full-length nuclear-encoded transcripts and mitochondrial-encoded RNA. The dynamic range of RNA-Seq allows for accurate identification and quantification of transcripts present at very low and high levels as well as the discovery of more transcripts, novel splicing junctions and novel exons than reported in previous microarray studies $[7,9,10]$. In addition to the identification of transcripts not previously reported in spermatozoal RNA, several known spermatozoal transcripts from a number of different species were also found. Gene ontology analysis of the highly abundant spermatozoal transcripts (FPKM>100) revealed that translation was the most predominant biological process represented. The presence of full-length transcripts in transcriptionally-silent spermatozoa suggests that these transcripts could be translated after spermatogenesis is complete, potentially contributing to capacitation and early embryogenesis $[1,3]$.

Spermatozoal RNA isolation procedures have been developed to maximize yield and ensure elimination of somatic cell RNA. The total amount of cryopreserved 
bovine spermatozoal RNA isolated in this study (31 fg RNA per spermatozoa) was comparable to the RNA content previously reported in bovine (10-140 fg), human (12.5 fg), rat (100 fg), porcine (5 fg), and equine (20 fg) spermatozoa [reviewed in 1 , 8].

In this study, RNA was isolated from the whole cryopreserved semen straw, after a wash to remove the cryoprotectant, without the removal of non-motile spermatozoa. Using the entire spermatozoa population is representative of the natural transcript variation present across a range of fertility scores for bulls used in artificial insemination and is consistent with the approach used in other studies [12, 21, 24, 34].

The focus of this study was to enrich for and sequence the polyA ${ }^{+}$transcripts present in transcriptionally-silent spermatozoa. The mitochondrial-encoded rRNAs and mRNAs sequenced in this population were some of the most abundant transcripts although these mitochondrial RNAs represented only $0.5 \%$ of the total transcripts. Mitochondrial rRNAs and mRNAs have been previously amplified in spermatozoa $[10,19]$ and the presence of these transcripts is likely due to intact mitochondria present during the RNA isolation procedure and the high mitochondrial activity of spermatozoa. Poly(A-) transcripts and microRNAs were not evaluated in this study but probably present in the total bovine spermatozoa RNA population [4].

Using RNA-Seq, we identified several full-length transcripts in the bovine cryopreserved spermatozoal transcript profile. While some of these transcripts were previously reported in spermatozoa, the presence of full-length transcripts could not be determined from the microarray studies. The most abundant full-length transcript, PRM1, has been reported in spermatozoa from other species as well, including humans 
and porcine $[7,13,20,35]$. The high level of $P R M I$ is probably due to retention of this transcript in elongating spermatids during the later stages of spermatogenesis. A function for $P R M 1$ after spermatozoa leave the testis is doubtful as Prml transcripts are rapidly degraded in the mouse embryo $[15,16]$. Other transcripts are delivered to the oocyte after fertilization, including the Y chromosome-linked $D B Y$ and RPS4Y, were not identified as full-length transcripts in this study, therefore, a functional role in embryogenesis for these transcripts is also unlikely [17].

Polyubiquitin is also an abundant full-length transcript in bovine spermatozoa. The ubiquitin system has several functions during spermiogenesis and fertilization, including: histone removal, removal of damaged epididymal spermatozoa, and aiding in zona penetration $[36,37]$. Disruption of the ubiquitin-proteosome pathway during spermatogenesis is characteristic of teratozoospermic males and can be detected in human spermatozoal RNA [22]. Spermatozoa-derived ubiquitin RNAs may also have a role in directing the degradation of paternal mitochondrial RNAs, ensuring exclusive maternal mitochondrial DNA inheritance [36]. Further investigation of a role for spermatozoal-derived polyubiqutin mRNA pre- and post-fertilization is warranted.

Previously reported spermatozoal transcripts involved in capacitation and fertilization were also identified as full-length, including: PLCZ1, CRISP2 and CLGN1. PLCZ1, a well-characterized activator of the calcium wave after fertilization, is translated in the oocyte and injections of PLCZ1 RNA into the oocyte are also sufficient for function [18]. PLCZ1 is present at lower amounts (FPKM=41.3) in the bovine spermatozoa transcript profile demonstrating that functional transcripts may not be the most abundant transcripts in this population. The presence of full-length 
CRISP2 could be indicative of potential translation at fertilization as CRISP2 is one of the spermatozoal proteins involved in oocyte binding [38]. The CLGN1 protein is necessary for heterodimerization of fertilization proteins $[39,40]$. The presence of spermatozoal mRNA for critical fertilization proteins may be necessary to ensure appropriate function.

A number of previously unreported spermatozoal transcripts are full-length and abundant in the bovine spermatozoal transcript profile including HMGB4, PSMA6, GTSF1, and CKS2 although a role of transcripts from spermatozoal-derived mRNAs is speculative. HMGB4 is found at the basal pole of elongating spermatids and is a transcriptional repressor [41]. PSMA6 is an alpha subunit of proteasomes; inhibition of spermatozoal proteosomes blocks fertilization by preventing spermatozoa penetration of the zona pellucida [42]. GTSF1 is critical for the suppression of retrotransposons in the male germ cells, as well as causing meiotic arrest in knockout mice [43]. CKS2 is critical in early embryonic development, where it controls cell proliferation [44]. In knockout studies of $C K S 2$ and $C K S 1$, embryos arrest development before the morula stage due to cyclin B1 downregulation [44].

A predominant function of the bovine spermatozoal transcripts with FPKM $>100$ is translation and includes abundant transcripts for ribosomal proteins, polyubiquitin (discussed above), eukaryotic translation initiation factors (EIF1 and EIF5), and eukaryotic translation elongation factors (EEF1Al and EEF1 $\gamma$ ). EIF1Al is present in human spermatozoa [24] but EIF1, EEFI $\gamma$ and EIF5 have not been previously reported in any species. The translation elongation factors EEFIAI and EEFI $\gamma$ were 
full-length in this study therefore a role for these transcripts in the early stage embryo is an interesting area for further investigation.

One-third of the transcripts with FPKM>100 were degraded (all exons were not mapped). A predominance of degraded transcripts was also found in the FPKM $<100$ transcript population although this was not quantified. A degraded RNA population is characteristic of the spermatozoal RNA populations isolated in previous studies $[7,8]$ and large subset of the spermatozoal mRNAs are probably remnants from gene expression during spermatogenesis and do not have a function. The relatively higher levels of most of the full-length transcripts is probably not due to a 3' end bias, which can occur with RNA-Seq, due to the RNA amplification protocol that selectively amplified full-length transcripts [45]. Although full-length transcripts were identified, the proportion of degraded and full-length transcripts for an individual transcript could not be distinguished and the abundance values reported probably represent a sum of the full-length and fragmented exons for each transcript and the levels of intact transcripts is then probably lower than these reported values. The presence of degraded mRNAs and full-length mRNAs are not necessarily mutually exclusive events and functional transcripts could be present in a heterogeneous population.

While the goal of this present study was to identify a full-range of poly $\left(\mathrm{A}^{+}\right)$ mRNAs present in bovine spermatozoa to identify candidates for further investigation, biological replicates were not conducted and individual bulls were pooled for RNASeq and for some validation although individuals with a wide range of known fertility scores were used. The pool of mRNA from our spermatozoa population contains several previously reported transcripts therefore the likelihood that the identified 
transcripts are only present in this population of bulls is low but additional transcripts may be identified in other individuals.

The diagnostic potential of the total spermatozoal RNA population (degraded and full-length transcripts) is emerging. Individual transcripts are stably regulated within and between individual males and perturbation of the ubiquitin-proteosome pathway during spermatogenesis could be detected in the spermatozoal RNA [22, 23]. The amount of specific transcripts, including PRM1, PRM2, CRISP2, CCT8, PEBP1 and $C D 36$, have also been correlated to fertility in humans and bulls $[10-12,20,46]$. These transcripts are full-length in this bovine spermatozoal transcript profile, so prediction of fertility for some of these transcripts may be due to a functional role (for example CRISP2) and not just a representation of transcription during spermatogenesis (for example, PRM1 and PRM2). If the degraded mRNA population is stably regulated, this population can also be used to as a diagnostic tool. Spermatozoal transcript populations also vary with motility, morphology, DNA integrity and seasons [47-51]. The spermatozoal transcript profile reported here was sequenced from a pool of bulls that represent a normal range of fertility scores. While the presence of specific transcripts did vary in an independent population of bulls, further quantitative analysis in a much larger population will better assess the level of individual bull variation and a correlation of transcript levels with fertility scores.

This is the first report of the spermatozoal transcript profile in any species using high-throughput sequencing, supporting the presence of mRNA in spermatozoa. Further studies of the spermatozoal mRNA candidates identified will contribute to our 
knowledge of the function of spermatozoal mRNA and expand our approaches to assay male fertility.

\section{References}

[1] Hamatani T. Human spermatozoal RNAs. Fertil Steril 2012; 97: 275-281.

[2] Johnson GD, Sendler E, Lalancette C, Hauser R, Diamond MP, Krawetz SA. Cleavage of rRNA ensures translational cessation in sperm at fertilization. Mol Hum Reprod 2011; 17: 721-726.

[3] Lalancette C, Miller D, Li Y, Krawetz SA. Paternal contributions: new functional insights for spermatozoal RNA. J Cell Biochem 2008; 104: 1570-1579.

[4] Krawetz SA, Kruger A, Lalancette C, Tagett R, Anton E, Draghici S, Diamond MP. A survey of small RNAs in human sperm. Hum Reprod 2011; 26: 3401-3412.

[5] Jenkins TG and Carrell DT. The sperm epigenome and potential implications for the developing embryo. Reproduction 2012; 143: 727-734.

[6] Liu W, Pang RTK, Chiu PCN, Wong BPC, Lao K, Lee K, Yeung WSB. Spermborne microRNA-34c is required for the first cleavage division in mouse. PNAS 2012; 109: 490-494.

[7] Gilbert I, Bissonnette N, Boissonneault G, Vallee M, Robert C. A molecular analysis of the population of mRNA in bovine spermatozoa. Reprod 2007; 133: 1073-1086.

[8] Das PJ, Paria N, Gustafson-Seabury A, Vishnoi M, Chaki SP, Love CC, Varner DD, Chowdhary BP, Raudsepp T. Total RNA isolation from stallion sperm and testis biopsies. Theriogenology 2010; 74: 1099-1106.

[9] Ostermeier GC, Dix DJ, Miller D, Khatri P, Krawetz SA. Spermatozoal RNA profiles of normal fertile men. Lancet 2002; 360: 772-777.

[10] Lalancette C, Thibault C, Bachand I, Caron N, Bissonnette N. Transcriptome analysis of bull semen with extreme nonreturn rate: use of suppression-subtractive 
hybridization to identify functional markers for fertility. Biol Reprod 2008; 78: 618635.

[11] Avendano C, Franchi A, Jones E, Oehninger S. Pregnancy-specific B-Iglycoprotein I and human leukocyte antigen-E mRNA in human sperm: differential expression in fertile and infertile men and evidence of a possible functional role during early development. Hum Reprod 2009; 24: 270-277.

[12] Arangasamy A, Kasimanickam VR, DeJarnette JM, Kasimanickam RK. Association of CRISP2, CCT8, PEBP1 mRNA abundance in sperm and sire conception rate in Holstein bulls. Theriogenology 2011; 76: 570-577.

[13] Kempisty B, Antosik P, Bukowska D, Jackowska M, Lianeri M, Jaskowski KM, Jagodzinski PP. Analysis of selected transcript levels in porcine spermatozoa, oocytes, zygotes and two-cell stage embryos. Reprod Fertil Dev 2008; 20: 513-518.

[14] Ostermeier GC, Miller D, Huntriss JD, Diamond MP, Krawetz SA. Delivering spermatozoan RNA to the oocyte. Nature 2004; 429: 154.

[15] Hayashi S, Yang J. Christenson L, Yanagimachi R, Hecht NB. Mouse preimplantation embryos developed from oocytes injected with round spermatids or spermatozoa have similar but distinct patterns of early messenger RNA expression. Biol Reprod 2003; 69: 1170-1176.

[16] Depa-Martynow M, Kempisty B, Jagodzinski P, Pawelczyk L, Jedrzejczak P. Impact of protamine transcripts and their proteins on the quality and fertilization ability of sperm and the development of preimplantation embryos. Reprod Biol 2012; 12: $57-72$.

[17] Yao C, Wang Z, Zhou Y, Xu W, Li Q, Ma D, Wang L, Qiao Z. A study of Y chromosome gene mRNA in human ejaculated spermatozoa. Mol Reprod Dev 2010; 77: 158-166.

[18] Swann K, Saunders CM, Rogers NT, Lai FA. PLCל (zeta): A sperm protein that triggers $\mathrm{Ca}^{2+}$ oscillations and egg activation in mammals. Sem Cell Dev Biol 2006; 17: 264-273.

[19] Gur Y and Breitbart H. Mammalian sperm translate nuclear-encoded protiens by mitochondrial-type ribosomes. Genes Dev 2006; 20: 411-416.

[20] Feugang JM, Rodriguez-Osorio N, Kaya A, Wang H, Page G, Ostermeier GC, Topper EK, Memili E. Transcriptome analysis of bull spermatozoa: implications for male fertility. Reprod Biomed Online 2010; 21: 312-324. 
[21] Ostermeier GC, Goodrich RJ, Diamond MP, Dix DJ, Krawetz SA. Toward using stable spermatozoal RNAs for prognostic assessment of male factor fertility. Fert Ster 2005; 26: 1687-1694.

[22] Platts AE, Dix DJ, Chemes HE, Thompson KE, Goodrich R, Rockett JC, Rawe VY, Quintana S, Diamond MP, Strader LF, Krawetz SA. Success and failure in human spermatogenesis as revealed by teratozoospermic RNAs. Hum Mol Genet 2007; 16: 763-773.

[23] Lalancette C, Platts AE, Johnson GD, Emery BR, Carrell DT, Krawetz SA. Identification of human sperm transcripts as candidate markers of male fertility. J Mol Med 2009; 87: 735-748.

[24] Dadoune JP, Pawlak A, Alfonsi MF, Siffroi JP. Identification of transcripts by macroarrays, RT-PCR and in situ hybridization in human ejaculate spermatozoa. Mol Hum Reprod 2005; 11: 133-140.

[25] Zhao Y, Li Q, Yao C, Wang Z, Zhou Y, Wang Y, Liu L, Wang Y, Wang L, Qiao Z. Characterization and quantification of mRNA transcripts in ejaculated spermatozoa of fertile men by serial analysis of gene expression. Hum Reprod 2006; 21: 1583 1590 .

[26] Wang Z, Gerstein M, Snyder M. RNA-Seq: A revolutionary tool for transcriptomics. Nat Rev Genet 2009; 10:57-63.

[27] Werner T. Next generation sequencing allows deeper analysis and understanding of genomes and transcriptomes including aspects to fertility. Reprod Fertil Dev 2011; 23(1): 75-80.

[28] Goecks, J, Nekrutenko, A, Taylor, J and The Galaxy Team. Galaxy: a comprehensive approach for supporting accessible, reproducible, and transparent computational research in the life sciences. Genome Biol. 2010 Aug 25; 11(8):R86.

[29] Blankenberg D, Von Kuster G, Coraor N, Ananda G, Lazarus R, Mangan M, Nekrutenko A, Taylor J. Galaxy: a web-based genome analysis tool for experimentalists. Curr Protoc Molec Biol 2010; Chapter 19: Unit 19.10.1-21.

[30] Giardine B, Riemer C, Hardison RC, Burhans R, Elnitski L, Shah P, Zhang Y, Blankenberg D, Albert I, Taylor J, Miller W, Kent WJ, Nekrutenko A. Galaxy: a platform for interactive large-scale genome analysis. Genome Res 2005; 15(10):14515 . 
[31] Trapnell C, Roberts A, Goff L, Pertea G, Kim D, Kelley DR, Pimentel H, Salzberg SL, Rinn JL, Pachter L. Differential gene and transcript expression analysis of RNA-seq experiments with TopHat and Cufflinks. Nat Protoc 2012; 7(3):562-578.

[32] Langmead B, Trapnell C, Pop M, Salzberg SL. Ultrafast and memory-efficient alignment of short DNA sequences to the human genome. Genome Biol 2009; 10(3): $\mathrm{R} 25$.

[33] Wang L, Wang S, Li W. RSeQC: Quality Control of RNA-seq experiments. Bioinformatics 2012; 28(16): 2184-2185.

[34] Wang H, Zhou Z, Xu M, Li J, Xiao J, Xu Z, Sha J. A spermatogenesis-related gene expression profile in human spermatozoa and its potential clinical applications. $\mathrm{J}$ Mol Med 2004; 317-324.

[35] Hecht N, Cavalcanti MC, Nayudu P, Behr R, Reichenback M, Weidner W, Steger K. Protamine-1 represents a sperm specific gene transcript: a study in Callithrix jacchus and Bos taurus. Andrologia 2011; 43(3):167-173.

[36] Sutovsky P. Ubiquitin-dependent proteolysis in mammalian spermatogenesis, fertilization and sperm quality control: killing three birds with on stone. Microsc Res Tech 2003; 61: 88-102.

[37] Yi YJ, Zimmerman SW, Manandhar G, Odhiambo JF, Kennedy C, Jonakova V, Manaskova-Postlerova P. Ubiquitin-activating enzyme (UBA1) is required for sperm capacitation, acrosomal exocytosis and sperm-egg coat penetration during porcine fertilization. Int J Androl 2012; 35(2): 196-210.

[38] Busso D, Goldweic NM, Hayashi M, Kasahara M, Cuasnicu PS. Evidence for the involvement of testicular protein CRISP2 in mouse sperm-egg fusion. Biol Reprod 2007; 76: 701-708.

[39] Ikawa M, Nakanishi T, Yamada S, Wada I, Kominami K, Tanaka H, Nozaki M, Nishimune Y, Okabe M. Calmegin is required for fertilin alpha/beta heterodimerization and sperm fertility. Dev Biol 2001; 240: 254-261.

[40] Yamagata K, Nakanishi T, Ikawa M, Yamaguchi R, Moss SB, Okabe M. Sperm from calmegin-deficient mouse have normal abilities for binding and fusion to the egg plasma membrane. Dev Biol 2002; 250:348-357. 
[41] Catena R, Escoffier E, Caron C, Khochbin S, Martianov I, Davidson I. HMGB4, a novel member of the HMGB family, is preferentially expressed in the mouse testis and localizes to the basal pole of elongating spermatids. Biol Reprod 2009; 80: 358366.

[42] Zimmerman SW, Manandhar G, Yi YJ, Gupta SK, Sutovsky M, Odhiambo JF, Powell MD, Miller DJ, Sutovsky P. Sperm proteasomes degrade sperm receptor on the egg zona pellucida during mammalian fertilization. PLOS one 2011; 6(2): e17256.

[43] Yoshimura T, Toyoda S, Kuramochi-Miyagawa S, Miyazaki T, Miyazaki S, Tashiro F, Yamato E, Nakano T, Miyazaki J. Gtsf1/Cue110, a gene encoding a protein with two copies of a CHHC Zn-finger motif, is involved in spermatogenesis and retrotransposon suppression in murine testes. Dev Biol 2009; 335: 216-227.

[44] Martinsson-Ahlzen HS, Liberal V, Grunenfelder B, Chaves SR, Spruck CH, Reed SI. Cyclin-dependent kinase-associated proteins $C k s 1$ and $C k s 2$ are essential during early embryogenesis and for cell cycle progression in somatic cells. Mol Cell Biol 2008; 28: 5698-5709.

[45] Costa V, Angelini C, De Feis I, Ciccodicola A. Uncovering the complexity of transcriptomes with RNA-Seq. J Biomed Biotechnol. 2010; 853916. Epub 2010 June 27.

[46] Steger K, Wilhelm J, Konrad L, Stalf T, Greb R, Deimer T, Kliesch S, Bergmann $\mathrm{M}$, Weidner $\mathrm{W}$. Both protamine-1 to protamine- 2 mRNA ratio and $\mathrm{Bcl} 2 \mathrm{mRNA}$ content in testicular spermatids and ejaculated spermatozoa discriminate between fertile and infertile men. Hum Reprod 2008; 23: 11-16.

[47] Aoki VW, Emery BR, Liu L, Carrell DT. Protamine levels vary between individual sperm cells of infertile human males and correlate with viability and DNA integrity. J Androl 2006; 27: 890-898.

[48] Lambard S, Galeraud-Denis I, Martin G, Levy R, Chocat A, Carreau S. Analysis and significance of mRNA in human ejaculated sperm from normozoospermic donors:relationship to sperm motility and capacitation. Mol Hum Reprod 2004; 10 : 535-541.

[49] Roudebush WE, Massey JB, Zhu J. Morphologically normal sperm have significantly greater total-RNA content than abnormal sperm. Int Congr Ser 2004; 193-196. 
[50] Yang CC, Lin YS, Hsu CC, Tsai MH, Wu SC, Cheng WTK. Seasonal effect of sperm messenger RNA profile of domestic swine. Anim Reprod Sci 2010; 119:76-84.

[51] Bissonnette N, Levesque-Sergerie JP, Thibault C, Boissonneault G. Spermatozoal transcriptome profiling for bull sperm motility: a potential tool to evaluate semen quality. Reprod 2009; 138:65-80. 


\section{Figures}

Figure 1. Purity of bovine cryopreserved spermatozoal RNA was confirmed by lack of somatic cell RNAs and genomic amplification. (A) Bioanalyzer analysis of testis RNA and spermatozoal RNA prior to amplification. (B) Cell-specific transcripts for testicular germ cells $(C-K I T)$, leukocytes $(C D 45)$ and epithelial cells $(C D H 1)$ did not amplify in the spermatozoal RNA (Lane S). M= 100 bp DNA marker, $\mathrm{T}=$ testis RNA positive control and $\mathrm{N}=$ negative control that does not include cDNA template. (C) The spermatozoal RNA (Lane S) does not contain genomic DNA compared to amplification of genomic EIF1 in spermatozoal cDNA spiked with genomic DNA (Lane G). $\mathrm{N}=$ negative control that does include cDNA template.

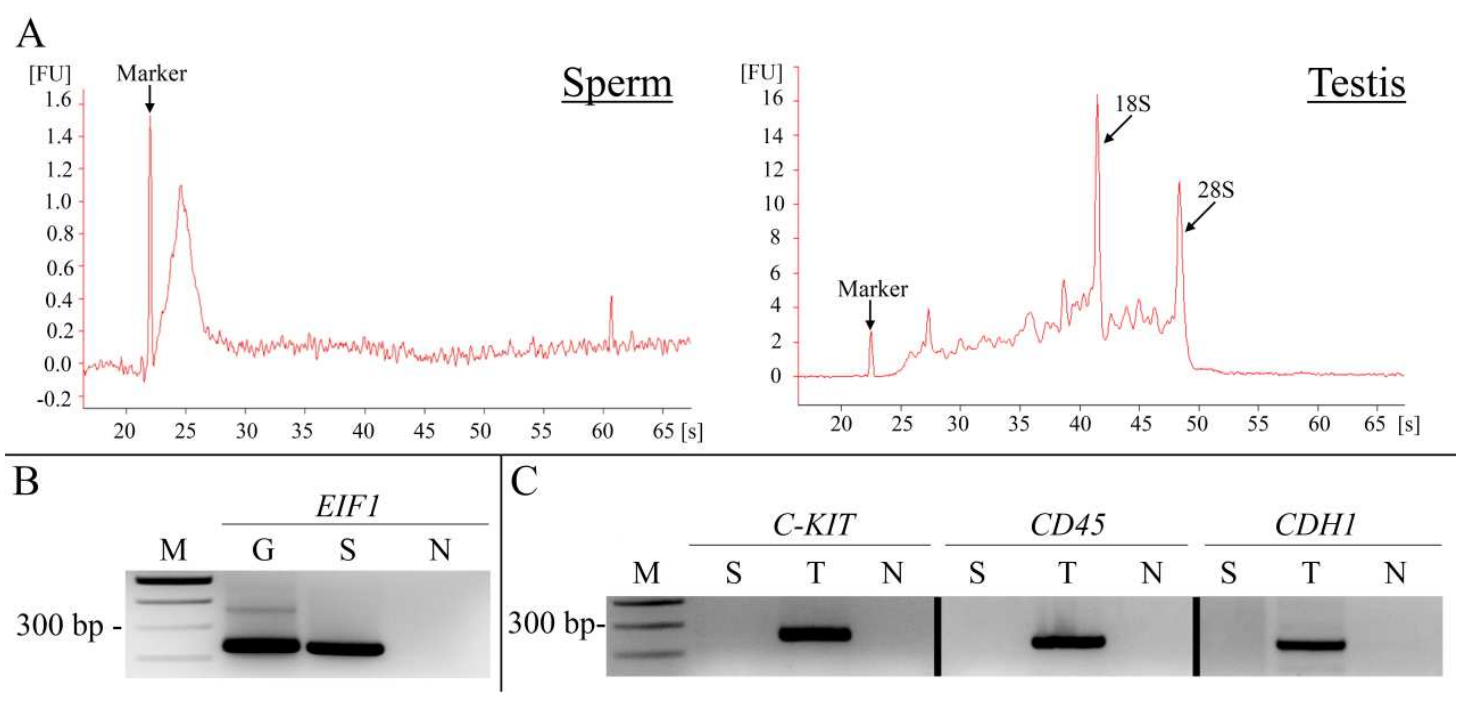


Figure 2. Correlation of qPCR transcript copy number and RNA-Seq FPKM based on nine transcripts. Axes are base $10 \log$ scale.

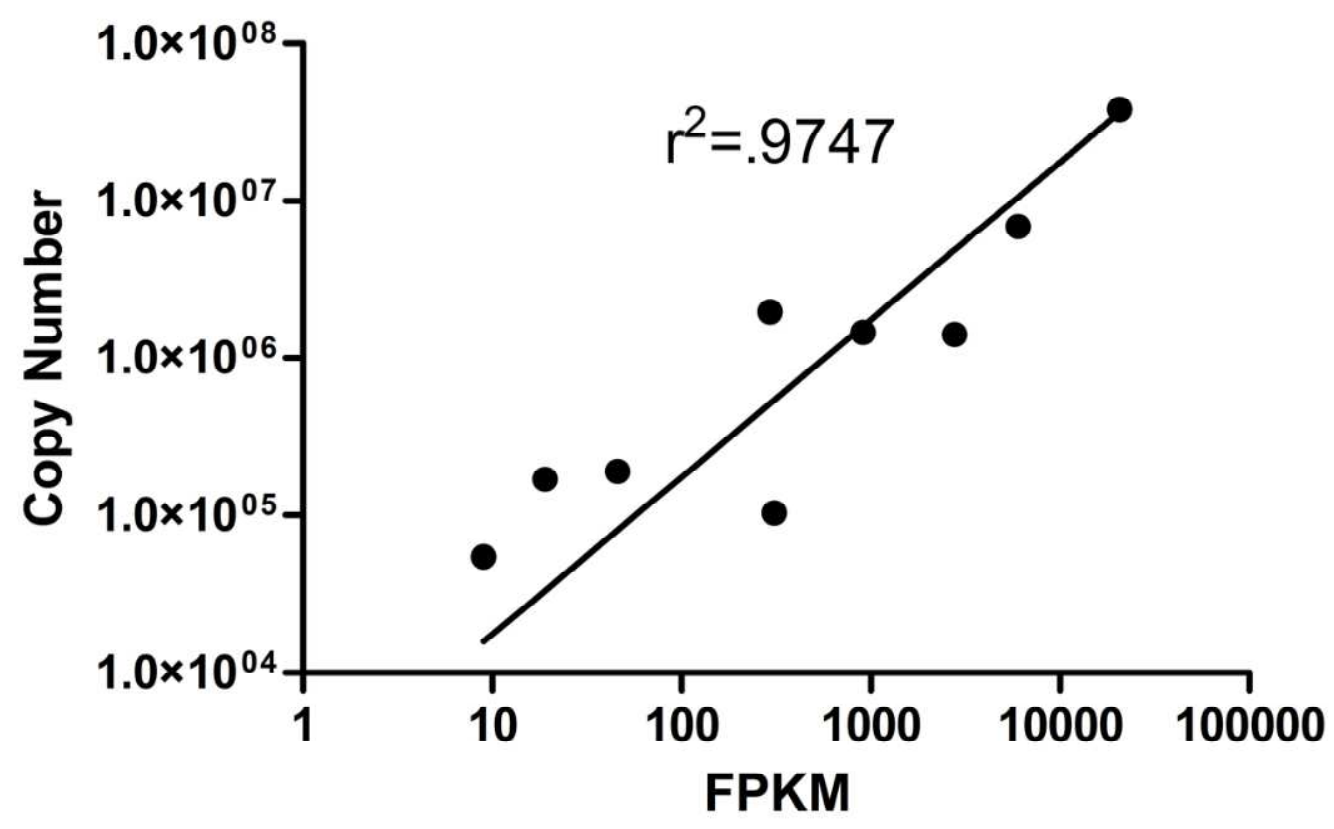


Figure 3. PCR amplification of (A) the 5' and 3' ends of DDX3Y, PLCZ1, CRISP2 and GSTM3 in amplified ds-cDNA. For 5' end primers, all primers begin in the first exon, and for 3' end primers, all primers end in the last exon. All primer sets are intronspanning. $\mathrm{N}=$ negative control that did not include $\mathrm{cDNA}$ template and $\mathrm{M}=100 \mathrm{bp}$ DNA marker. (B) Transcripts for GSTM3 and GTSF1 were PCR amplified using primers within the first and last exons in order to capture full-length transcripts. The cDNA for this section was used from the 3-bull pool created from a Superscript III Reverse Transcription of mRNA (Invitrogen, Carlsbad, CA)

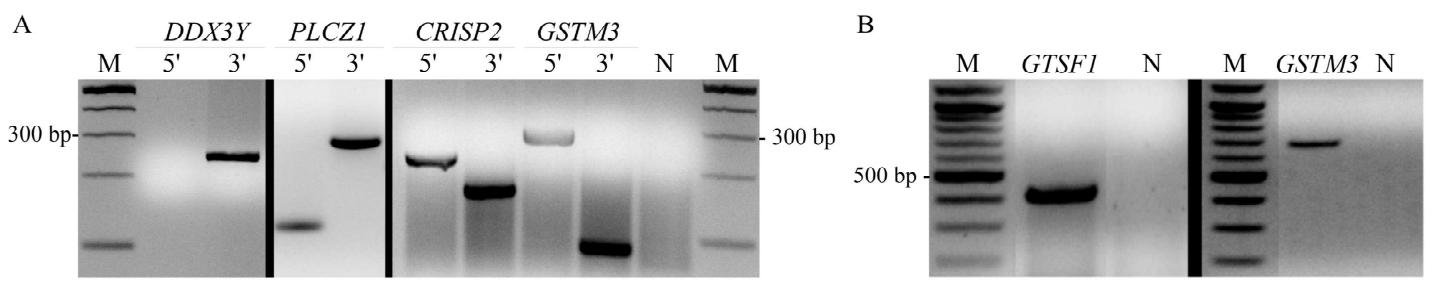


Figure 4. PCR amplification of select transcripts in individual bull spermatozoa amplified cDNA

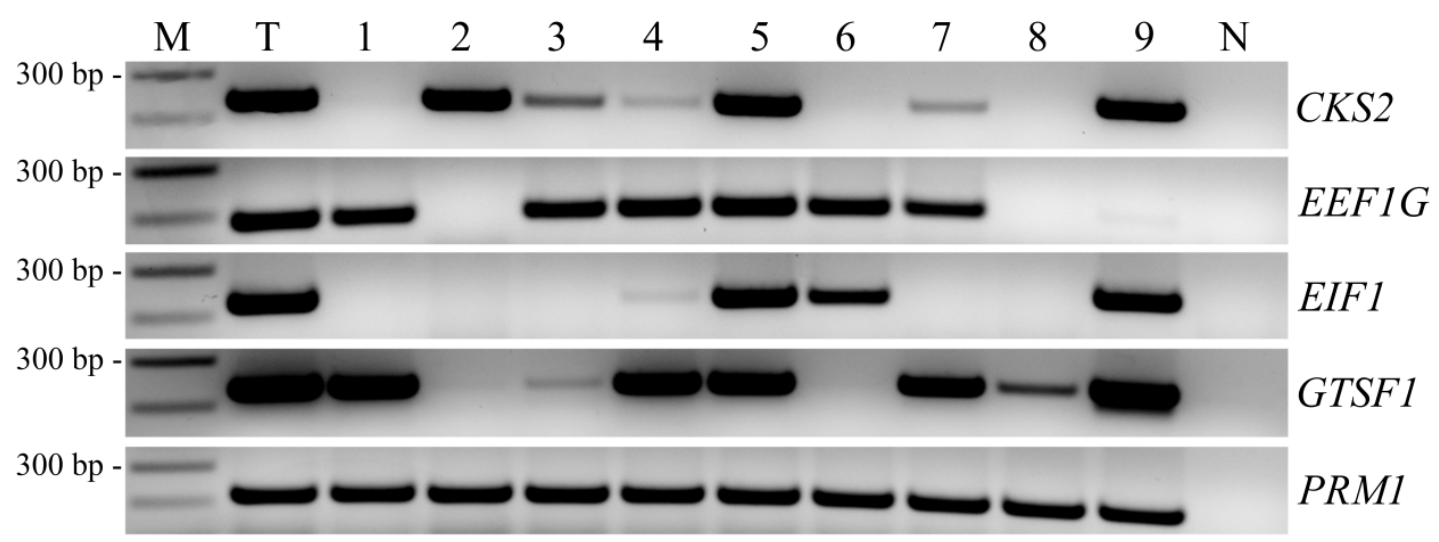




\section{$\underline{\text { Tables }}$}

Table 1. Bovine primer sequences. *Genomic DNA amplicon which includes 144 bp intron

\begin{tabular}{|c|c|c|c|c|c|}
\hline \multirow[b]{2}{*}{$\begin{array}{l}\text { Gene } \\
\text { Symbol }\end{array}$} & \multirow[b]{2}{*}{$\begin{array}{l}\text { Genbank } \\
\text { ID }\end{array}$} & & \multicolumn{2}{|c|}{ Primer Sequences } & \multirow[b]{2}{*}{$\begin{array}{l}\text { Product } \\
\text { Size (bp) }\end{array}$} \\
\hline & & & Forward & Reverse & \\
\hline BTF3A & AB098942 & qPCR & $\begin{array}{l}\text { 5'- GGTGGTTCATAGAACAGCAACAGC } \\
-3^{\prime}\end{array}$ & $\begin{array}{l}\text { 5'- GGCACCAAGCTGGTTTAAGATGCT } \\
-3^{\prime}\end{array}$ & 244 \\
\hline$C D 45$ & AJ400864 & PCR & $\begin{array}{l}\text { 5'- TGGACGAAATTGCATCCCTCAGGA } \\
-3^{\prime}\end{array}$ & $\begin{array}{l}5 \text { '- TGGTCAGGACGTTTACAGCTCACA } \\
-3^{\prime}\end{array}$ & 237 \\
\hline $\mathrm{CDH1}$ & AY508164 & PCR & $\begin{array}{l}\text { 5'- ACCATGGACTTCTGCCAGAGGAAT } \\
-3^{\prime}\end{array}$ & $\begin{array}{l}\text { 5'- TGGTCACCTGGTCTTTGTTCTGGT - } \\
\text { 3' }\end{array}$ & 244 \\
\hline CHMP5 & BC103182 & qPCR & 5'- TGGCACGGTGGACAGCAGAG - 3' & 5' - TGGGCGAGATTGTCCCGCTG - 3' & 189 \\
\hline$C-K I T$ & AF263827 & PCR & $\begin{array}{l}\text { 5'- TATAGCACCATTGATGACAGCACA } \\
-3^{\prime}\end{array}$ & $\begin{array}{l}\text { 5'- TTATCTCCTCGACAACTTTCCACT - } \\
\text { 3' }\end{array}$ & 268 \\
\hline CKS 2 & BC105331 & $\begin{array}{l}\text { Individual } \\
\text { Variation }\end{array}$ & 5' - GAGTCGAGTCGTTGCCTTCA -3' & 5'-GGACACCAAGTCTCCTCCAC -3' & 248 \\
\hline \multirow[t]{2}{*}{ CRISP2 } & BC109478 & 5 ' Set & 5'-CGGCCGCTCTGCAACAGAAG-3' & 5'-GGAAGCAGCACAGCGGTCAGA-3' & 120 \\
\hline & & 3' Set & 5'-CACCTTGCGGCA & CGCC-3' & 165 \\
\hline \multirow[t]{2}{*}{$D D X 3 Y$} & GQ259590 & 5' Set & $\begin{array}{l}\text { 5'- TTGTTTCCGGTAGACCAACCTGTG- } \\
\text { 3' }\end{array}$ & 5'- AGCGCCCTTTGCTAGCTGTACT -3' & 220 \\
\hline & & 3' Set & $\begin{array}{l}\text { 5'- GGCCGTTCTAGGAGATTCAGTGG - } \\
\text { 3' }\end{array}$ & $\begin{array}{l}\text { 5'- } \\
\text { CAACTGAATCTGCTTTCCAGCCAAG - } \\
\text { 3' }\end{array}$ & 246 \\
\hline EIF1 & BC103170 & qPCR & $\begin{array}{l}\text { 5'- AAGGGTGATGATCTGCTTCCTGCT - } \\
\text { 3' }\end{array}$ & $\begin{array}{l}\text {-5'- AACTGGCATATGTTCTTGCGCTGG - } \\
3^{\prime}\end{array}$ & - $235(379)^{*}$ \\
\hline EIF4A & BC103130 & qPCR & $\begin{array}{l}\text { 5'- TGCCTTCTGATGTGCTTGAGGTGA - } \\
\text { 3' }\end{array}$ & $\begin{array}{l}\text { 5'- TGAAGTCTCGGGCATGCATCTTCT - } \\
\text { 3' }\end{array}$ & 246 \\
\hline \multirow[t]{3}{*}{ GSTM3 } & BC112491 & 5' Set & 5'-GCGCTAAGGCACACAGGCGA-3' & 5'-TGCGGGCGATGTAGCGCAAG-3' & 290 \\
\hline & & 3' Set & 5'-TGTGCCGTTTTGAGGCTTTGGAG-3' & $\begin{array}{l}\text { 5'- } \\
\text { GGGCCATCTTGTTGTTGACAGGCAT-3' }\end{array}$ & 90 \\
\hline & & $5^{\prime}$ to $3^{\prime}$ Exon & 5'-GCGCTAAGGCACACAGGCGA-3' & $\begin{array}{l}\text { 5'- } \\
\text { GGGCCATCTTGTTGTTGACAGGCAT-3' }\end{array}$ & 679 \\
\hline GTSF1 & BC102713 & 5' to 3' Exon & 5'-ACAAACTGGCAACTTGTCCCT-3' & 5'-GAACACACTGTAGCGGGAAGA-3' & 427 \\
\hline$H M G B 4$ & 4 BC109790 & qPCR & 5'- AGCTGGTCGGTGGTGCAGGT -3' & 5'- GCAAGCATGTCTTCCGGGC -3' & 167 \\
\hline \multirow[t]{3}{*}{ PLCZ1 } & BC114836 & 5' Set & 5'- GGTGCCCGGCCAACCAGTTAT -3' & 5'- TGCCGCTTGGCAAGAAAGGG -3' & 138 \\
\hline & & 3' Set & 5'- GTGGTATCCAGTTGCCTCCCAGT -3' & ' 5'- GCGGGCTCAAGACTCTCACCC -3' & 319 \\
\hline & & qPCR & 5'- CGGGTGGTCGGAATCCCACTCT -3' & 5'- AATTCCCTGGCTGCCAACTTTGT -3' & 194 \\
\hline PRM1 & BC108207 & qPCR & $\begin{array}{l}\text { 5'- } \\
\text { AAGAAGATGTCGCAGACGAAGGAG - } \\
\text { 3' } \\
\text { 5'- }\end{array}$ & $\begin{array}{l}\text { 5'- ACAGGTGGCATTGTTCGTTAGCAG } \\
-3^{\prime}\end{array}$ & 228 \\
\hline PSMA6 & BC110260 & qPCR & $\begin{array}{l}\text { ACAGTGGAAACTGCGATTACATGCC - } \\
3^{\prime}\end{array}$ & 5' - ACAGGCAAGTGGCGTCACGG - 3' & 205 \\
\hline SEC61G & GBC102186 & qPCR & 5'- GCAGACGCGGAGCAGACATCA -3' & 5'- AGCGAATCCTATTGCTGTTGCCA -3' & 155 \\
\hline
\end{tabular}


Table 2. Top 10 bovine spermatozoal transcripts based on FPKM.

Million fragments mapped (FPKM)

\begin{tabular}{llll}
\hline \multicolumn{4}{c}{ Million fragments mapped (FPKM) } \\
\hline Gene Symbol & Gene Name & Accession Number & FPKM \\
PRM1 & Protamine 1 & BC108207; M14559 & $20667 ; 12461$ \\
LOC783058 & Hypothetical Protein & BC126791 & 10290 \\
HMGB4 & High mobility group box 4 & BC109790 & 6022 \\
LOC404073 & Histone 2B variant PT15 & BC108210; AF315690 & $3048 ; 2158$ \\
CHMP5 & Chromatin modifying protein 5 & BC103182 & 2778 \\
TMSB4X & Thymosin beta 4 X-linked & FJ795030 & 2487 \\
LOC281370 & Polyubiquitin & AB099044 & 2426 \\
GSTM3 & Glutathione S-transferase mu 3 & BC112491 & 2374 \\
N/A & cDNA clone IMAGE:7944277 & BC134702 & 2050 \\
KIF5C & Kinesin family member 5C & BC151732 & 1862
\end{tabular}


Table 3. Comparing 5' and 3' exons in transcripts from previous literature

\begin{tabular}{|c|c|c|c|c|c|c|c|}
\hline \multirow[b]{2}{*}{ Transcript } & \multirow[b]{2}{*}{$\begin{array}{l}\text { Accession } \\
\#\end{array}$} & \multirow[b]{2}{*}{ FPKM } & \multicolumn{2}{|c|}{$\begin{array}{l}\text { End Exons } \\
\text { Intact }\end{array}$} & \multirow[b]{2}{*}{ Reference } & \multirow[b]{2}{*}{ Species } & \multirow[b]{2}{*}{$\begin{array}{l}\text { Accession } \\
\#\end{array}$} \\
\hline & & & $5^{\prime}$ & $3^{\prime}$ & & & \\
\hline PRM1 & BC108207 & 20667.2 & $\mathrm{Y}$ & $\mathrm{Y}$ & $\begin{array}{l}\text { Ziyyat, 1999; Gilbert, 2007; } \\
\text { Kempisty, 2008; Hecht, 2010; } \\
\text { Feugang, 2010 }\end{array}$ & $\begin{array}{l}\mathrm{H} ; \mathrm{B} ; \\
\mathrm{P} ; \mathrm{B} \\
\mathrm{Ma} ; \mathrm{B}\end{array}$ & BC108207 \\
\hline CHMP5 & BC103182 & 2778.08 & $\mathrm{~N}$ & $\mathrm{~N}$ & Zhao et al., 2006; Lalancette, 2008 & $\mathrm{H}$ & BC103182 \\
\hline TNP1 & X16171 & 1287.96 & $\mathbf{Y}$ & $\mathbf{Y}$ & Iguchi, 2006 & M & X16171 \\
\hline TNP2 & BC109800 & 1206.79 & $\mathrm{~N}$ & $\mathrm{Y}$ & Miller, 2005 & M & BC109800 \\
\hline SMCP & BC109542 & 938.502 & $\mathbf{Y}$ & $\mathbf{Y}$ & $\begin{array}{l}\text { Iguchi, 2006; Yang } 2009 \\
\text { Kempisty, 2008; Ostermeier, 2004; }\end{array}$ & M & BC109542 \\
\hline CLGN & BC103401 & 220.011 & $\mathbf{Y}$ & $\mathbf{Y}$ & Wang, 2004 & $\mathrm{P}$ & BC103401 \\
\hline TMBIM6 & BC102469 & 196.512 & $\mathrm{~N}$ & $\mathrm{Y}$ & Gilbert, 2007 & $\mathrm{~B}$ & BC102469 \\
\hline PGK2 & BC110004 & 173.412 & $\mathbf{Y}$ & $\mathbf{Y}$ & Iguchi, 2006 & M & BC110004 \\
\hline $\begin{array}{l}\text { H2AFZ } \\
\text { LOC789867 }\end{array}$ & BC109743 & 166.742 & $\mathrm{~N}$ & $\mathrm{Y}$ & Gilbert, 2007 & $\mathrm{~B}$ & BC109743 \\
\hline $\begin{array}{l}\text { (EF-1, } \\
\text { EEF1A1) }\end{array}$ & AF013213 & 133.722 & $\mathbf{Y}$ & $\mathbf{Y}$ & Lalancette, 2008; Zhao, 2006 & $\mathrm{~B}$ & AF013213 \\
\hline AKAP4 & AF100170 & 126.623 & $\mathbf{Y}$ & $\mathbf{Y}$ & Gilbert, 2007; Ostermeier, 2004 & $\mathrm{~B}$ & AF100170 \\
\hline RPS4Y & BC133507 & 53.0481 & $\mathrm{~N}$ & $\mathrm{Y}$ & Yao, 2009 & M & BC133507 \\
\hline PRM2 & BC109783 & 45.5481 & $\mathrm{~N}$ & $\mathrm{Y}$ & Hecht, 2010 & $\mathrm{~B}, \mathrm{Ma}$ & BC109783 \\
\hline CLU & BC118223 & 44.045 & $\mathrm{~N}$ & $\mathrm{Y}$ & Gilbert, 2007; Kempisty, 2008 & $\mathrm{~B} ; \mathrm{P}$ & BC118223 \\
\hline ACTG1 & BC102951 & 43.7095 & $\mathrm{~N}$ & $\mathrm{Y}$ & Gilbert, 2007 & $\mathrm{~B}$ & BC102951 \\
\hline PLCZ1 & AY646356 & 41.3639 & $\mathbf{Y}$ & $\mathbf{Y}$ & $\begin{array}{l}\text { Hamatani, } 2012 \\
\text { Lambard et al., 2004; Kumar et al. }\end{array}$ & $\mathrm{H}$ & AY646356 \\
\hline MYCBP & BC109848 & 39.731 & $\mathbf{Y}$ & $\mathbf{Y}$ & $\begin{array}{l}1993 \\
\text { Bissonette, 2009; Arangasamy, }\end{array}$ & $\mathrm{H}$ & BC109848 \\
\hline PEBP1 & BC102389 & 29.3446 & $\mathrm{~N}$ & $\mathrm{Y}$ & 2011 & $\mathrm{~B}$ & BC102389 \\
\hline SPAG4 & BC109514 & 25.6132 & $\mathrm{~N}$ & $\mathrm{Y}$ & Gilbert, 2007 & $\mathrm{~B}$ & BC109514 \\
\hline CCT8 & AF136609 & 17.9915 & $\mathrm{~N}$ & $\mathrm{~N}$ & Arangasamy, 2011 & $\mathrm{~B}$ & AF136609 \\
\hline DDX3Y & FJ659845 & 10.9846 & $\mathrm{~N}$ & $\mathrm{~N}$ & Sekiguchi, 2004; Yao, 2009 & $\mathrm{H} ; \mathrm{M}$ & FJ659845 \\
\hline PPIH & BC120220 & 10.946 & $\mathrm{~N}$ & $\mathrm{~N}$ & Gilbert, 2007 & $\mathrm{~B}$ & BC120220 \\
\hline STRBP & BC123453 & 7.26818 & $\mathrm{~N}$ & $\mathrm{~N}$ & Gilbert, 2007 & $\mathrm{~B}$ & BC123453 \\
\hline FLOT1 & BC104516 & 5.44937 & $\mathrm{~N}$ & $\mathrm{~N}$ & Gilbert, 2007 & B & BC104516 \\
\hline CSN2 & S67277 & 4.76535 & $\mathrm{~N}$ & $\mathrm{Y}$ & Feugang, 2010 & $\mathrm{~B}$ & S67277 \\
\hline CRISP2 & BC109478 & 4.07274 & $\mathbf{Y}$ & $\mathbf{Y}$ & Arangasamy, 2011; Zhao, 2006 & B & BC109478 \\
\hline EIF2B2 & BC123823 & 2.93951 & $\mathrm{~N}$ & $\mathrm{~N}$ & Gilbert, 2007 & B & BC123823 \\
\hline SPATA20 & BC123689 & 2.16637 & $\mathrm{~N}$ & $\mathrm{~N}$ & Gilbert, 2007 & B & BC123689 \\
\hline
\end{tabular}


Table 4. Top 10 previously unreported full-length bovine spermatozoal transcripts based on FPKM.

\begin{tabular}{llll} 
Gene Symbol & Gene Name & Accession Number & FPKM \\
\hline HMGB4 & High mobility group box 4 & BC109790 & 6022 \\
TMSB4X & Thymosin beta 4 X-linked & FJ795030 & 2487 \\
PSMA6 & Proteosome subunit, alpha type, 6 & BC110260 & 913 \\
GTSF1 & Gametocyte specific factor 1 & BC102713 & 896 \\
ZNF474 & Zinc finger protein 474 & BC108236 & 817 \\
COX7C & Cytochrome oxidase subunit 7c & X15725 & 733 \\
COX7A2 & Cytochrome oxidase subunit 7a polypeptide 2 & DQ347636 & 719 \\
MLF1 & Myeloid leukemia factor 1 & BC109859 & 517 \\
PFDN5 & Prefoldin subunit 5 & BC102252 & 405 \\
GABARAP & GABA(A) receptor-associated protein & AJ297742 & 385
\end{tabular}


Table 5. Top 10 gene ontology categories for all spermatozoal transcripts FPKM $>0$ and for transcripts with FPKM $>100 . \mathrm{CP}=$ Catabolic Process, $\mathrm{Bi}=$ Binding, $\mathrm{Org}=$ Organelle, $\mathrm{NMBO}=$ Non-Membrane Bounded Organelle, $\mathrm{TTA}=$ transmembrane transporter activity.

\begin{tabular}{|c|c|c|c|}
\hline \multicolumn{2}{|l|}{$\begin{array}{c}\text { All Transcripts } \\
\text { (\% of Transcripts Per Category) }\end{array}$} & \multicolumn{2}{|c|}{$\begin{array}{l}\text { Transcripts with FPKM > } 100 \\
\text { (\% of Transcripts Per Category) }\end{array}$} \\
\hline Translation & 4.91 & Translation & 14.55 \\
\hline Proteolysis Involved In Cellular Protein CP & 4.48 & Protein Localization & 6.18 \\
\hline Cellular Protein $\mathrm{CP}$ & 4.39 & Precursor Metabolites And Energy & 5.82 \\
\hline Modification-Dependent Protein CP & 4.02 & Sexual Reproduction & 5.45 \\
\hline Modification-Dependent Macromolecule CP & 4.02 & Spermatogenesis & 5.09 \\
\hline Cellular Macromolecule CP & 4.00 & Male Gamete Generation & 5.09 \\
\hline Protein $\mathrm{CP}$ & 3.57 & Gamete Generation & 5.09 \\
\hline RNA Processing & 3.52 & Multicellular Organism Reproduction & 5.09 \\
\hline Macromolecule CP & 3.40 & Reproductive Process & 5.09 \\
\hline mRNA Processing & 3.14 & Protein Transport & 5.09 \\
\hline
\end{tabular}

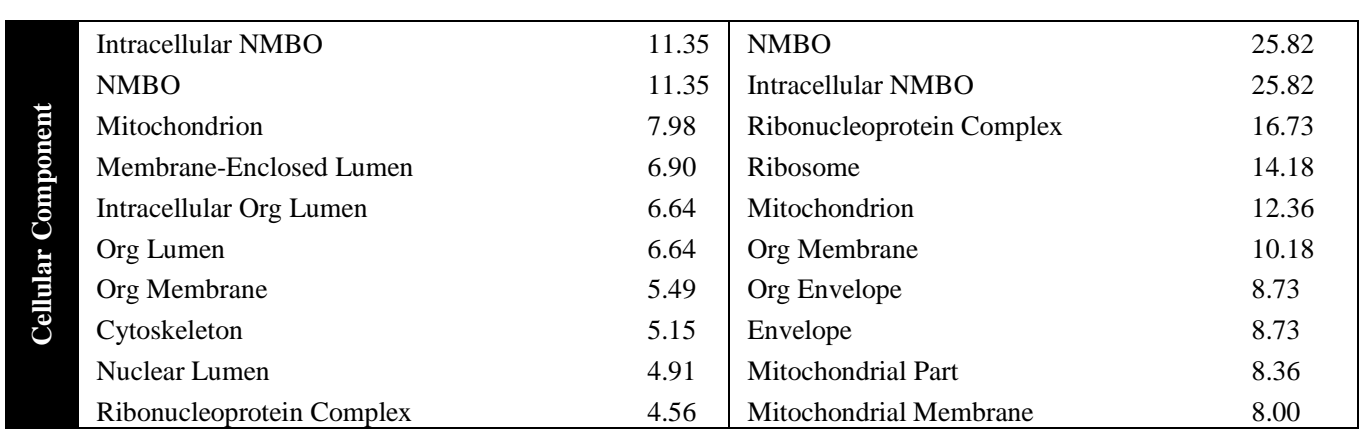

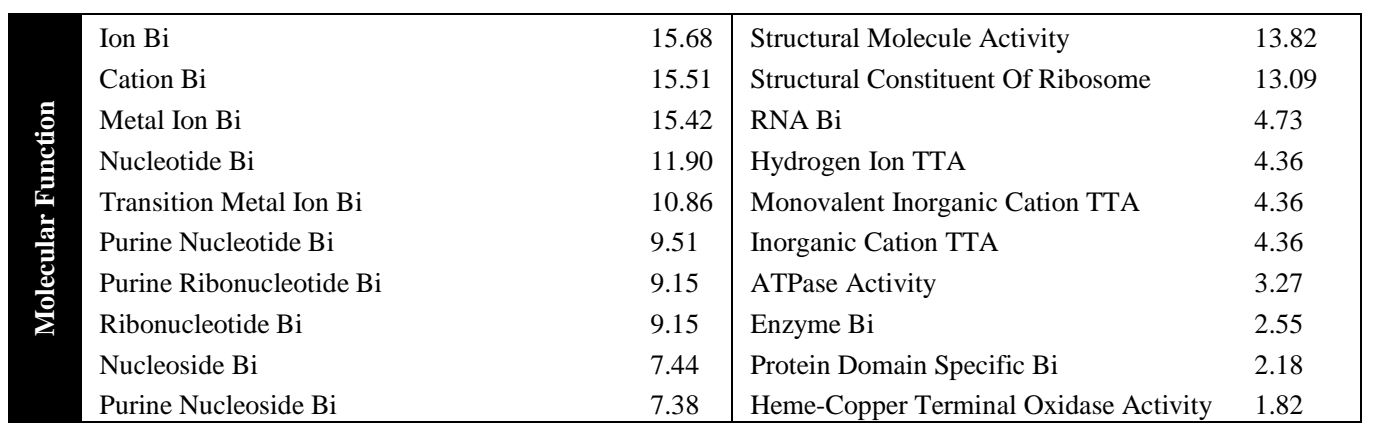


Table 6. Full-Length Trasncripts for the population of FPKM $>100$.

\begin{tabular}{|c|c|c|c|c|c|c|}
\hline $\begin{array}{l}\text { Genbank } \\
\text { ID }\end{array}$ & $\begin{array}{l}\text { Official Gene } \\
\text { Symbol }\end{array}$ & Full Name & FPKM & $\begin{array}{c}\text { Full Length } \\
\text { Transcript }\end{array}$ & $\begin{array}{l}\text { 5' Exon } \\
\text { intact }\end{array}$ & $\begin{array}{l}\text { 3' Exon } \\
\text { intact }\end{array}$ \\
\hline & & Percent Yes: & & 65.76 & 70.65 & 88.59 \\
\hline AB098851 & ORCS10804 & $\begin{array}{l}\text { Bos Taurus Mitochondrial } \\
\text { Rna, Similar To 16S Rrna }\end{array}$ & 383371 & $\mathrm{Y}$ & $\mathrm{Y}$ & $\mathrm{Y}$ \\
\hline AB098854 & ORCS10931 & $\begin{array}{l}\text { Bos Taurus Mitochondrial } \\
\text { Rna, Similar To 16S Rrna }\end{array}$ & 301214 & $\mathrm{Y}$ & $\mathrm{Y}$ & $\mathrm{Y}$ \\
\hline AB098841 & ORCS10096 & $\begin{array}{l}\text { Bos Taurus Mitochondrial } \\
\text { Rna, Similar To 16S Rrna }\end{array}$ & 216612 & $\mathrm{Y}$ & $\mathrm{Y}$ & $\mathrm{Y}$ \\
\hline AB098863 & ORCS11599 & $\begin{array}{l}\text { Bos Taurus Mitochondrial } \\
\text { Rna, Similar To 16S Rrna }\end{array}$ & 149030 & $\mathrm{Y}$ & $\mathrm{Y}$ & $\mathrm{Y}$ \\
\hline AB098844 & ORCS10257 & $\begin{array}{l}\text { Bos Taurus Mitochondrial } \\
\text { Rna, Similar To 12S Rrna }\end{array}$ & 145266 & $\mathrm{Y}$ & $\mathrm{Y}$ & Y \\
\hline AB099138 & ORCS12829 & $\begin{array}{l}\text { Bos Taurus Mitochondrial } \\
\text { Rna, Similar To 16S Rrna }\end{array}$ & 133966 & $\mathrm{Y}$ & Y & $\mathrm{Y}$ \\
\hline AB098853 & ORCS10848 & $\begin{array}{l}\text { Bos Taurus Mitochondrial } \\
\text { Rna, Similar To } 12 \text { S Rrna }\end{array}$ & 82000.2 & $\mathrm{Y}$ & Y & $\mathrm{Y}$ \\
\hline BC108207 & PRM1 & Bos Taurus Protamine 1 & 20667.2 & $\mathrm{Y}$ & $\mathrm{Y}$ & $\mathrm{Y}$ \\
\hline DQ347622 & $H 97$ & $\begin{array}{l}\text { Bos taurus clone } \mathrm{H} 97 \mathrm{COX} 1 \\
\text { mRNA }\end{array}$ & 15042.7 & $\mathrm{Y}$ & Y & $\mathrm{Y}$ \\
\hline M14559 & PRM1 & Protamine 1 & 12460.6 & $\mathrm{Y}$ & $\mathrm{Y}$ & $\mathrm{Y}$ \\
\hline DQ347619 & $H 31$ & $\begin{array}{l}\text { Bos taurus clone H31 ND4 } \\
\text { mRNA }\end{array}$ & 11070.1 & $\mathrm{Y}$ & $\mathrm{Y}$ & $\mathrm{Y}$ \\
\hline DQ347618 & ATP6 & $\begin{array}{l}\text { Bos Taurus Clone A14 Atp6 } \\
\text { Mrna }\end{array}$ & 10379.2 & $\mathrm{Y}$ & $\mathrm{Y}$ & $\mathrm{Y}$ \\
\hline BC126791 & LOC783058 & $\begin{array}{l}\text { Bos taurus hypothetical } \\
\text { protein LOC783058 }\end{array}$ & 10289.7 & $\mathrm{Y}$ & Y & $\mathrm{Y}$ \\
\hline AB098808 & ORCS12903 & $\begin{array}{l}\text { Bos taurus mitochondrial } \\
\text { mRNA for similar to } \\
\text { ATPase } 6\end{array}$ & 10255 & $\mathrm{Y}$ & $\mathrm{Y}$ & $\mathrm{Y}$ \\
\hline DQ347621 & $H 63$ & $\begin{array}{l}\text { Bos taurus clone } \mathrm{H} 63 \mathrm{COX} 2 \\
\text { mRNA }\end{array}$ & 9735.03 & $\mathrm{Y}$ & $\mathrm{Y}$ & $\mathrm{Y}$ \\
\hline AB099097 & ORCS11619 & $\begin{array}{l}\text { Bos Taurus Mitochondrial } \\
\text { Rna, Similar To D-Loop } \\
\text { Bos Taurus Mitochondrial }\end{array}$ & 8300.97 & $\mathrm{Y}$ & Y & $\mathrm{Y}$ \\
\hline AB098776 & ORCS12073 & $\begin{array}{l}\text { Mrna For Similar To } \\
\text { Cytochrome Oxidase III } \\
\text { Bos Taurus Mitochondrial }\end{array}$ & 7772.1 & $\mathrm{Y}$ & $\mathrm{Y}$ & $\mathrm{Y}$ \\
\hline AB098777 & ORCS12084 & $\begin{array}{l}\text { Mrna For Similar To } \\
\text { Cytochrome Oxidase III }\end{array}$ & 6720.22 & $\mathrm{Y}$ & $\mathrm{Y}$ & Y \\
\hline BC109790 & $H m g b 4$ & High-Mobility Group Box 4 & 6021.96 & $\mathrm{Y}$ & $\mathrm{Y}$ & $\mathrm{Y}$ \\
\hline AB099131 & ORCS11856 & $\begin{array}{l}\text { Bos taurus mitochondrial } \\
\text { RNA, similar to } 12 \mathrm{~S} \text { rRNA }\end{array}$ & 5795.61 & $\mathrm{Y}$ & Y & $\mathrm{Y}$ \\
\hline DQ347627 & $\mathrm{H} 4 \mathrm{O}$ & $\begin{array}{l}\text { Bos taurus clone } \mathrm{H} 40 \mathrm{COX} 2 \\
\text { mRNA }\end{array}$ & 5408.65 & Y & Y & $\mathrm{Y}$ \\
\hline AB099077 & ORCS13694 & $\begin{array}{l}\text { Bos taurus mitochondrial } \\
\text { mRNA for similar to } \\
\text { cytochrome oxidase I }\end{array}$ & 5297.64 & $\mathrm{Y}$ & Y & $\mathrm{Y}$ \\
\hline AB098902 & ORCS10210 & $\begin{array}{l}\text { Bos taurus mRNA for } \\
\text { similar to cytochrome } \\
\text { oxidase I }\end{array}$ & 5046 & $\mathrm{Y}$ & Y & Y \\
\hline AB099009 & ORCS12081 & $\begin{array}{l}\text { Bos taurus mRNA for } \\
\text { similar to cytochrome } b\end{array}$ & 4319.09 & $\mathrm{Y}$ & Y & $\mathrm{Y}$ \\
\hline AB098967 & ORCS11394 & $\begin{array}{l}\text { Bos Taurus Mrna For } \\
\text { Similar To Cytochrome B }\end{array}$ & 3394.89 & $\mathrm{Y}$ & Y & $\mathrm{Y}$ \\
\hline BC126791 & $M G C 148328$ & $\begin{array}{l}\text { Bos taurus hypothetical } \\
\text { protein LOC783058, mRNA }\end{array}$ & 3198.14 & $\mathrm{Y}$ & Y & Y \\
\hline FJ976184 & ND5 & $\begin{array}{l}\text { Bos taurus NADH } \\
\text { dehydrogenase subunit } 5 \\
\text { (ND5) mRNA }\end{array}$ & 3091.53 & $\mathrm{Y}$ & $\mathrm{Y}$ & $\mathrm{Y}$ \\
\hline BC108210 & LOC404073 & Histone H2B Variant Pt15 & 3047.5 & $\mathrm{Y}$ & $\mathrm{Y}$ & $\mathrm{Y}$ \\
\hline AB098941 & ORCS10715 & $\begin{array}{l}\text { Bos taurus mRNA for } \\
\text { similar to cytochrome b }\end{array}$ & 2918.85 & $\mathrm{Y}$ & $\mathrm{Y}$ & $\mathrm{Y}$ \\
\hline BC103182 & Chmp5 & $\begin{array}{l}\text { Chromatin Modifying } \\
\text { Protein } 5\end{array}$ & 2778.08 & $\mathrm{~N}$ & $\mathrm{~N}$ & $\mathrm{~N}$ \\
\hline
\end{tabular}




\begin{tabular}{|c|c|c|c|c|c|c|}
\hline AB098789 & ORCS12473 & $\begin{array}{l}\text { Bos Taurus Mitochondrial } \\
\text { Mrna For Similar To } \\
\text { Cytochrome Oxidase III }\end{array}$ & 2521.74 & $\mathrm{Y}$ & $\mathrm{Y}$ & $\mathrm{Y}$ \\
\hline FJ795030 & LOC785455 & Thymosin Beta 4, X-Linked & 2486.99 & $\mathrm{Y}$ & $\mathrm{Y}$ & $\mathrm{Y}$ \\
\hline AB099044 & LOC281370 & Polyubiquitin & 2425.89 & $\mathrm{Y}$ & Y & $\mathrm{Y}$ \\
\hline BC112491 & GSTM3 & $\begin{array}{l}\text { Glutathione S-Transferase } \\
\text { Mu } 3 \text { (Brain) }\end{array}$ & 2373.84 & $\mathrm{Y}$ & Y & $\mathrm{Y}$ \\
\hline AF315690 & LOC404073 & Histone H2B Variant Pt15 & 2158.22 & $\mathrm{Y}$ & $\mathrm{Y}$ & $\mathrm{Y}$ \\
\hline AB098774 & ORCS11961 & $\begin{array}{l}\text { Bos taurus mitochondrial } \\
\text { mRNA for similar to } \\
\text { cytochrome oxidase III }\end{array}$ & 2133.68 & $\mathrm{Y}$ & $\mathrm{Y}$ & Y \\
\hline AB099096 & ORCS11109 & $\begin{array}{l}\text { Bos taurus mitochondrial } \\
\text { RNA, similar to D-loop }\end{array}$ & 2091.43 & $\mathrm{Y}$ & $\mathrm{Y}$ & $\mathrm{Y}$ \\
\hline BC134702 & IMAGE:7944277 & $\begin{array}{l}\text { Bos taurus cDNA clone } \\
\text { IMAGE: } 7944277\end{array}$ & 2050.08 & $\mathrm{Y}$ & $\mathrm{Y}$ & $\mathrm{Y}$ \\
\hline AB098801 & ORCS12731 & $\begin{array}{l}\text { Bos taurus mitochondrial } \\
\text { mRNA for similar to } \\
\text { cytochrome oxidase III }\end{array}$ & 2029.43 & $\mathrm{Y}$ & $\mathrm{Y}$ & $\mathrm{Y}$ \\
\hline BC151732 & KIF5C & Kinesin Family Member 5C & 1862.47 & $\mathrm{Y}$ & $\mathrm{Y}$ & $\mathrm{Y}$ \\
\hline BC123382 & LOC777592 & $\begin{array}{l}\text { Hypothetical Protein } \\
\text { Loc } 777592\end{array}$ & 1846.72 & $\mathrm{~N}$ & $\mathrm{~N}$ & $\mathrm{Y}$ \\
\hline BC126793 & $I M A G E: 8056303$ & $\begin{array}{l}\text { Bos taurus cDNA clone } \\
\text { IMAGE: } 8056303\end{array}$ & 1808.5 & $\mathrm{~N}$ & $\mathrm{~N}$ & $\mathrm{Y}$ \\
\hline AB098980 & ORCS11606 & $\begin{array}{l}\text { Bos taurus mitochondrial } \\
\text { mRNA for similar to NADH } \\
\text { dehydrogenase subunit } 1\end{array}$ & 1586.19 & $\mathrm{Y}$ & $\mathrm{Y}$ & $\mathrm{Y}$ \\
\hline AB098969 & ORCS11414 & $\begin{array}{l}\text { Bos taurus mRNA for } \\
\text { similar to NADH } \\
\text { dehydrogenase subunit } 1\end{array}$ & 1563.82 & $\mathrm{Y}$ & $\mathrm{Y}$ & $\mathrm{Y}$ \\
\hline BC114001 & LOC281370 & Polyubiquitin & 1520.12 & $\mathrm{Y}$ & $\mathrm{Y}$ & $\mathrm{Y}$ \\
\hline BC111648 & $M G C 137055$ & $\begin{array}{l}\text { Hypothetical Protein } \\
\text { Mgc137055 }\end{array}$ & 1466.25 & $\mathrm{Y}$ & Y & Y \\
\hline AB098767 & ORCS11606 & $\begin{array}{l}\text { Bos taurus mitochondrial } \\
\text { mRNA, similar to protein } 1\end{array}$ & 1310.8 & $\mathrm{Y}$ & $\mathrm{Y}$ & $\mathrm{Y}$ \\
\hline X16171 & tnpl & Transition Protein 1 & 1287.96 & $\mathrm{Y}$ & Y & Y \\
\hline BC109730 & C13H2Oorf79 & $\begin{array}{l}\text { Chromosome } 20 \text { Open } \\
\text { Reading Frame } 79 \text { Ortholog }\end{array}$ & 1237.94 & $\mathrm{Y}$ & $\mathrm{Y}$ & $\mathrm{Y}$ \\
\hline BC142065 & IMAGE:8037824 & $\begin{array}{l}\text { Bos taurus cDNA clone } \\
\text { IMAGE: } 8037824\end{array}$ & 1224.68 & $\mathrm{Y}$ & $\mathrm{Y}$ & $\mathrm{Y}$ \\
\hline BC109800 & LOC781496 & $\begin{array}{l}\text { Similar To Tnp2 Protein; } \\
\text { Transition Protein } 2 \text { (During } \\
\text { Histone To Protamine } \\
\text { Replacement) }\end{array}$ & 1206.79 & $\mathrm{~N}$ & $\mathrm{~N}$ & $\mathrm{Y}$ \\
\hline BC126791 & IMAGE:30957795 & $\begin{array}{l}\text { Bos taurus hypothetical } \\
\text { protein LOC783058, mRNA }\end{array}$ & 1137.99 & $\mathrm{Y}$ & $\mathrm{Y}$ & $\mathrm{Y}$ \\
\hline AB098750 & LOC614114 & $\begin{array}{l}\text { Cytochrome C Oxidase } \\
\text { Subunit Vib Pseudogene }\end{array}$ & 1099.5 & $\mathrm{~N}$ & $\mathrm{~N}$ & $\mathrm{Y}$ \\
\hline BC111151 & $I M A G E: 8052434$ & $\begin{array}{l}\text { Bos taurus cDNA clone } \\
\text { IMAGE: } 8052434\end{array}$ & 993.402 & $\mathrm{~N}$ & $\mathrm{~N}$ & Y \\
\hline K00243 & tRNA-Leu & $\begin{array}{l}\text { Bovine Mitochondrial Leu- } \\
\text { Trna-Tag }\end{array}$ & 972.836 & $\mathrm{Y}$ & $\mathrm{Y}$ & Y \\
\hline AY796023 & Smcp & $\begin{array}{l}\text { Sperm Mitochondria- } \\
\text { Associated Cysteine-Rich } \\
\text { Protein }\end{array}$ & 938.502 & $\mathrm{Y}$ & $\mathrm{Y}$ & $\mathrm{Y}$ \\
\hline BC109478 & IMAGE: 8048928 & $\begin{array}{l}\text { Bos taurus cysteine-rich } \\
\text { secretory protein } 2, \text { mRNA }\end{array}$ & 933.969 & $\mathrm{Y}$ & $\mathrm{Y}$ & Y \\
\hline BC103421 & Spal7 & $\begin{array}{l}\text { Sperm Autoantigenic } \\
\text { Protein } 17\end{array}$ & 927.374 & $\mathrm{Y}$ & $\mathrm{Y}$ & Y \\
\hline BC110260 & Psma6 & $\begin{array}{l}\text { Proteasome (Prosome, } \\
\text { Macropain) Subunit, Alpha } \\
\text { Type, } 6\end{array}$ & 913.21 & $\mathrm{Y}$ & $\mathrm{Y}$ & $\mathrm{Y}$ \\
\hline BC102663 & C12orf54 & $\begin{array}{l}\text { Chromosome } 12 \text { Open } \\
\text { Reading Frame } 54 \text { Ortholog }\end{array}$ & 897.064 & $\mathrm{Y}$ & $\mathrm{Y}$ & Y \\
\hline BC102713 & GTSF1 & $\begin{array}{l}\text { Gametocyte Specific Factor } \\
1 \\
\text { Chromosome } 1 \text { Open }\end{array}$ & 896.368 & $\mathrm{Y}$ & $\mathrm{Y}$ & $\mathrm{Y}$ \\
\hline BC102609 & C3H1orf182 & $\begin{array}{l}\text { Reading Frame } 182 \\
\text { Ortholog }\end{array}$ & 887.309 & $\mathrm{Y}$ & $\mathrm{Y}$ & $\mathrm{Y}$ \\
\hline
\end{tabular}




\begin{tabular}{|c|c|c|c|c|c|c|}
\hline BC102599 & GTSF1L & $\begin{array}{l}\text { Gametocyte Specific Factor } \\
\text { 1-Like }\end{array}$ & 861.791 & $\mathrm{Y}$ & $\mathrm{Y}$ & Y \\
\hline BC108236 & ZNF474 & Zinc Finger Protein 474 & 816.725 & $\mathrm{Y}$ & $\mathrm{Y}$ & $\mathrm{Y}$ \\
\hline BC102973 & LOC539855 & Histone H3-Like & 805.895 & $\mathrm{Y}$ & $\mathrm{Y}$ & $\mathrm{Y}$ \\
\hline AB099083 & LOC281370 & $\begin{array}{l}\text { Ubiquitin C; Polyubiquitin; } \\
\text { Ubiquitin A-52 Residue } \\
\text { Ribosomal Protein Fusion } \\
\text { Product } 1\end{array}$ & 797.874 & $\mathrm{Y}$ & $\mathrm{Y}$ & $\mathrm{Y}$ \\
\hline DQ347600 & $A 24$ & $\begin{array}{l}\text { Bos Taurus Clone H1 } \\
\text { Atpase Na+/K+ } \\
\text { Transporting Beta } 3 \\
\text { Polypeptide-Like Mrna }\end{array}$ & 786.943 & $\mathrm{Y}$ & $\mathrm{Y}$ & Y \\
\hline BC126792 & LOC784495 & $\begin{array}{l}\text { Hypothetical Protein } \\
\text { Loc784495 }\end{array}$ & 741.663 & $\mathrm{Y}$ & $\mathrm{Y}$ & $\mathrm{Y}$ \\
\hline X15725 & $\operatorname{Cox} 7 c$ & $\begin{array}{l}\text { Cytochrome C Oxidase } \\
\text { Subunit Viic }\end{array}$ & 732.771 & $\mathrm{Y}$ & Y & Y \\
\hline DQ347636 & COX7A2 & $\begin{array}{l}\text { Cytochrome C Oxidase } \\
\text { Subunit Viia Polypeptide } 2 \\
\text { (Liver) }\end{array}$ & 719.358 & $\mathrm{Y}$ & $\mathrm{Y}$ & $\mathrm{Y}$ \\
\hline BC109926 & $I Q C F 5$ & Iq Motif Containing F5 & 707.481 & $\mathrm{Y}$ & $\mathrm{Y}$ & $\mathrm{Y}$ \\
\hline AB098957 & LOC281370 & Polyubiquitin & 677.922 & $\mathrm{Y}$ & $\mathrm{Y}$ & Y \\
\hline BC102598 & tnpl & $\begin{array}{l}\text { Transition Protein } 1 \text { (During } \\
\text { Histone To Protamine } \\
\text { Replacement) }\end{array}$ & 676.993 & $\mathrm{Y}$ & Y & Y \\
\hline BC103105 & CISD1 & Cdgsh Iron Sulfur Domain 1 & 656.043 & $\mathrm{~N}$ & $\mathrm{~N}$ & $\mathrm{Y}$ \\
\hline BC114790 & IMAGE: 8063641 & $\begin{array}{l}\text { Bos taurus cDNA clone } \\
\text { IMAGE: } 8063641\end{array}$ & 619.729 & $\mathrm{~N}$ & $\mathrm{~N}$ & Y \\
\hline BC109542 & Smcp & $\begin{array}{l}\text { Sperm Mitochondria- } \\
\text { Associated Cysteine-Rich } \\
\text { Protein }\end{array}$ & 604.724 & $\mathrm{Y}$ & $\mathrm{Y}$ & Y \\
\hline BC148014 & $r p l 23$ & Ribosomal Protein L23 & 599.605 & $\mathrm{Y}$ & Y & Y \\
\hline BC102582 & MP68 & $\begin{array}{l}6.8 \text { Kda Mitochondrial } \\
\text { Proteolipid } \\
\text { Leo1, Paf1/Rna Polymerase }\end{array}$ & 584.314 & $\mathrm{~N}$ & $\mathrm{~N}$ & $\mathrm{Y}$ \\
\hline Z86042 & $L E O 1$ & $\begin{array}{l}\text { Ii Complex Component, } \\
\text { Homolog (S. Cerevisiae) }\end{array}$ & 562.891 & $\mathrm{Y}$ & $\mathrm{Y}$ & $\mathrm{Y}$ \\
\hline BC110036 & Clph & $\begin{array}{l}\text { Chromosome } 4 \text { Open } \\
\text { Reading Frame } 35 \text { Ortholog }\end{array}$ & 545.537 & $\mathrm{Y}$ & $\mathrm{Y}$ & Y \\
\hline DQ347576 & $S L C 25 A 5$ & $\begin{array}{l}\text { (Mitochondrial Carrier; } \\
\text { Adenine Nucleotide } \\
\text { Translocator), Member } 5\end{array}$ & 542.739 & $\mathrm{Y}$ & $\mathrm{Y}$ & $\mathrm{Y}$ \\
\hline M62428 & $L O C 281370$ & $\begin{array}{l}\text { Ubiquitin C; Polyubiquitin; } \\
\text { Ubiquitin A-52 Residue } \\
\text { Ribosomal Protein Fusion } \\
\text { Product } 1\end{array}$ & 538.61 & $\mathrm{~N}$ & $\mathrm{~N}$ & $\mathrm{Y}$ \\
\hline K00194 & tRNA-Glu & $\begin{array}{l}\text { Bovine Mitochondrial Glu- } \\
\text { Trna-Uuc }\end{array}$ & 533.929 & $\mathrm{Y}$ & $\mathrm{Y}$ & $\mathrm{Y}$ \\
\hline BC111614 & LOC768323 & $\begin{array}{l}\text { Hypothetical Protein } \\
\text { Loc768323 }\end{array}$ & 522.375 & $\mathrm{Y}$ & $\mathrm{Y}$ & $\mathrm{Y}$ \\
\hline BC109859 & $M L F 1$ & $\begin{array}{l}\text { Myeloid Leukemia Factor } 1 \\
\text { Similar To Ribosomal }\end{array}$ & 516.634 & $\mathrm{Y}$ & $\mathrm{Y}$ & $\mathrm{Y}$ \\
\hline AY911357 & rpl31 & $\begin{array}{l}\text { Protein L31; Ribosomal } \\
\text { Protein L31 }\end{array}$ & 507.005 & Y & Y & $\mathrm{Y}$ \\
\hline AY260742 & LIS1 & $\begin{array}{l}\text { Bos taurus platelet } \\
\text { activating factor } \\
\text { acetylhydrolase } 45 \mathrm{kDa} \\
\text { subunit brain isoform (LIS1) } \\
\text { mRNA }\end{array}$ & 503.684 & $\mathrm{Y}$ & $\mathrm{Y}$ & $\mathrm{Y}$ \\
\hline J03604 & $G L U L$ & $\begin{array}{l}\text { Glutamate-Ammonia Ligase } \\
\text { (Glutamine Synthetase) }\end{array}$ & 500.939 & $\mathrm{Y}$ & $\mathrm{Y}$ & $\mathrm{Y}$ \\
\hline BC102702 & LOC782520 & Ribosomal Protein S29 & 497.777 & $\mathrm{Y}$ & $\mathrm{Y}$ & $\mathrm{Y}$ \\
\hline DQ347636 & COX7A2 & $\begin{array}{l}\text { Cytochrome C Oxidase } \\
\text { Subunit Viia Polypeptide } 2 \\
\text { (Liver) }\end{array}$ & 496.514 & $\mathrm{Y}$ & Y & Y \\
\hline BC109927 & MORN2 & Morn Repeat Containing 2 & 472.825 & $\mathrm{Y}$ & $\mathrm{Y}$ & $\mathrm{Y}$ \\
\hline BC105360 & spata6 & $\begin{array}{l}\text { Spermatogenesis Associated } \\
6\end{array}$ & 453.406 & Y & $\mathrm{Y}$ & $\mathrm{Y}$ \\
\hline
\end{tabular}




\begin{tabular}{|c|c|c|c|c|c|c|}
\hline AF294616 & TMSB10 & Thymosin Beta 10 & 451.9 & $\mathrm{~N}$ & $\mathrm{~N}$ & $\mathrm{Y}$ \\
\hline BC102650 & $M G C 128040$ & $\begin{array}{l}\text { Hypothetical Protein } \\
\text { Mgc128040 }\end{array}$ & 442.179 & $\mathrm{Y}$ & $\mathrm{Y}$ & $\mathrm{Y}$ \\
\hline BC149673 & $M G C 152346$ & $\begin{array}{l}\text { Uncharacterized Protein } \\
\text { Loc } 285141 \text { Homolog }\end{array}$ & 440.761 & $\mathrm{Y}$ & $\mathrm{Y}$ & $\mathrm{Y}$ \\
\hline BC126781 & $T X N D C 8$ & $\begin{array}{l}\text { Thioredoxin Domain } \\
\text { Containing } 8 \text { (Spermatozoa) }\end{array}$ & 433.154 & Y & $\mathrm{Y}$ & Y \\
\hline S79980 & RPL37 & ribosomal protein L37 & 432.006 & $\mathrm{Y}$ & $\mathrm{Y}$ & $\mathrm{Y}$ \\
\hline AB099079 & LOC789867 & $\begin{array}{l}\text { Eukaryotic Translation } \\
\text { Elongation Factor } 1 \text { Alpha } 1\end{array}$ & 431.873 & $\mathrm{Y}$ & $\mathrm{Y}$ & Y \\
\hline BC102748 & rpl32 & Ribosomal Protein L32 & 419.736 & $\mathrm{Y}$ & $\mathrm{Y}$ & $\mathrm{Y}$ \\
\hline BC111614 & LOC768323 & $\begin{array}{l}\text { Hypothetical Protein } \\
\text { Loc768323 }\end{array}$ & 414.631 & Y & $\mathrm{Y}$ & $\mathrm{Y}$ \\
\hline $\mathrm{BC} 102252$ & PFDN5 & Prefoldin Subunit 5 & 404.632 & $\mathrm{Y}$ & $\mathrm{Y}$ & Y \\
\hline BC102044 & RPL37A & Ribosomal Protein L37A & 403.288 & $\mathrm{~N}$ & $\mathrm{Y}$ & $\mathrm{N}$ \\
\hline BC109951 & $C A P Z A 3$ & $\begin{array}{l}\text { Capping Protein (Actin } \\
\text { Filament) Muscle Z-Line, } \\
\text { Alpha } 3\end{array}$ & 402.076 & $\mathrm{Y}$ & $\mathrm{Y}$ & Y \\
\hline BC102248 & LOC281370 & Polyubiquitin & 401.415 & $\mathrm{Y}$ & $\mathrm{Y}$ & $\mathrm{Y}$ \\
\hline BC120080 & $C A L M$ & Calmodulin-Like & 395.156 & $\mathrm{Y}$ & $\mathrm{Y}$ & $\mathrm{Y}$ \\
\hline BC142077 & IMAGE:8050622 & $\begin{array}{l}\text { Bos taurus cDNA clone } \\
\text { IMAGE: } 8050622\end{array}$ & 393.899 & $\mathrm{~N}$ & $\mathrm{~N}$ & $\mathrm{Y}$ \\
\hline AY186585 & $G L U L$ & $\begin{array}{l}\text { Glutamate-Ammonia Ligase } \\
\text { (Glutamine Synthetase) }\end{array}$ & 392.537 & $\mathrm{Y}$ & $\mathrm{Y}$ & Y \\
\hline DQ347578 & $A 17$ & $\begin{array}{l}\text { Bos taurus clone A17 actin } \\
\text { cytoplasmic } 2 \text { mRNA }\end{array}$ & 387.604 & Y & $\mathrm{Y}$ & Y \\
\hline AJ297742 & GABARAP & $\begin{array}{l}\text { Gaba(A) Receptor- } \\
\text { Associated Protein }\end{array}$ & 384.967 & $\mathrm{Y}$ & $\mathrm{Y}$ & Y \\
\hline BC142060 & DNAJB7 & $\begin{array}{l}\text { Dnaj (Hsp40) Homolog, } \\
\text { Subfamily B, Member } 7\end{array}$ & 366.633 & $\mathrm{Y}$ & $\mathrm{Y}$ & Y \\
\hline BC108144 & $B A N F 2$ & $\begin{array}{l}\text { Barrier To Autointegration } \\
\text { Factor } 2\end{array}$ & 359.621 & $\mathrm{Y}$ & $\mathrm{Y}$ & $\mathrm{Y}$ \\
\hline BC114198 & IMAGE: 8055902 & $\begin{array}{l}\text { Bos taurus cDNA clone } \\
\text { IMAGE: } 8055902\end{array}$ & 357.25 & Y & $\mathrm{Y}$ & Y \\
\hline BC105331 & $C K S 2$ & $\begin{array}{l}\text { Cdc28 Protein Kinase } \\
\text { Regulatory Subunit } 2\end{array}$ & 351.893 & $\mathrm{Y}$ & $\mathrm{Y}$ & $\mathrm{Y}$ \\
\hline BC114201 & IMAGE:8056539 & $\begin{array}{l}\text { Bos taurus cDNA clone } \\
\text { IMAGE: } 8056539\end{array}$ & 348.138 & $\mathrm{Y}$ & $\mathrm{Y}$ & $\mathrm{Y}$ \\
\hline BC149889 & DCUN1D1 & $\begin{array}{l}\text { Dcn1, Defective In Cullin } \\
\text { Neddylation 1, Domain } \\
\text { Containing } 1 \text { (S. Cerevisiae) }\end{array}$ & 342.726 & Y & $\mathrm{Y}$ & Y \\
\hline AF109198 & CLIC4 & $\begin{array}{l}\text { Chloride Intracellular } \\
\text { Channel } 4\end{array}$ & 338.487 & Y & $\mathrm{Y}$ & $\mathrm{Y}$ \\
\hline BC126766 & $F A M 24 A$ & Similar To Protein Fam24A & 335.134 & $\mathrm{Y}$ & $\mathrm{Y}$ & Y \\
\hline BC110256 & Fam71d & $\begin{array}{l}\text { Family With Sequence } \\
\text { Similarity 71, Member D } \\
\text { Ortholog }\end{array}$ & 335.075 & Y & $\mathrm{Y}$ & Y \\
\hline BC109624 & cetnl & Centrin, Ef-Hand Protein, 1 & 332.853 & $\mathrm{~N}$ & $\mathrm{~N}$ & Y \\
\hline BC102682 & SERF2 & Small Edrk-Rich Factor 2 & 330.258 & $\mathrm{~N}$ & $\mathrm{~N}$ & $\mathrm{Y}$ \\
\hline BC102249 & rps11 & Ribosomal Protein S11 & 327.944 & Y & $\mathrm{Y}$ & $\mathrm{Y}$ \\
\hline BC148018 & rps17 & Ribosomal Protein S17 & 327.412 & $\mathrm{Y}$ & $\mathrm{Y}$ & $\mathrm{Y}$ \\
\hline BC109989 & C13H20ORF71 & $\begin{array}{l}\text { Chromosome } 20 \text { Open } \\
\text { Reading Frame } 71 \text { Ortholog }\end{array}$ & 326.017 & $\mathrm{Y}$ & $\mathrm{Y}$ & Y \\
\hline BC102437 & atoxl & $\begin{array}{l}\text { Atx } 1 \text { Antioxidant Protein } 1 \\
\text { Homolog (Yeast) }\end{array}$ & 320.276 & $\mathrm{Y}$ & $\mathrm{Y}$ & Y \\
\hline DQ347614 & LOC784052 & $\begin{array}{l}\text { 40S Ribosomal Protein S26- } \\
\text { 2-Like }\end{array}$ & 319.419 & $\mathrm{Y}$ & $\mathrm{Y}$ & $\mathrm{Y}$ \\
\hline BC109725 & $S A A 4$ & $\begin{array}{l}\text { Serum Amyloid A4, } \\
\text { Constitutive }\end{array}$ & 319.23 & $\mathrm{Y}$ & $\mathrm{Y}$ & $\mathrm{Y}$ \\
\hline U19802 & btg 1 & $\begin{array}{l}\text { B-Cell Translocation Gene } \\
\text { 1, Anti-Proliferative }\end{array}$ & 316.825 & $\mathrm{~N}$ & $\mathrm{~N}$ & Y \\
\hline BC108179 & RPL38 & Ribosomal Protein L38 & 316.575 & Y & $\mathrm{Y}$ & $\mathrm{Y}$ \\
\hline BC111617 & Tmco2 & $\begin{array}{l}\text { Transmembrane And } \\
\text { Coiled-Coil Domains } 2\end{array}$ & 313.784 & $\mathrm{~N}$ & $\mathrm{~N}$ & Y \\
\hline BC114194 & IMAGE:8063913 & $\begin{array}{l}\text { Bos taurus cDNA clone } \\
\text { IMAGE: } 8063913\end{array}$ & 311.9 & $\mathrm{Y}$ & $\mathrm{Y}$ & $\mathrm{Y}$ \\
\hline BC103057 & $U Q C R B$ & Ubiquinol-Cytochrome C & 309.82 & $\mathrm{Y}$ & $\mathrm{Y}$ & Y \\
\hline
\end{tabular}




\begin{tabular}{|c|c|c|c|c|c|c|}
\hline & & Reductase Binding Protein & & & & \\
\hline BC102186 & $\sec 61 g$ & Sec61 Gamma Subunit & 309.446 & $\mathrm{Y}$ & $\mathrm{Y}$ & $\mathrm{Y}$ \\
\hline AB098960 & ORCS11043 & $\begin{array}{l}\text { Bos taurus mRNA for } \\
\text { similar to poly(A)-binding } \\
\text { protein } 1\end{array}$ & 307.612 & $\mathrm{Y}$ & Y & $\mathrm{Y}$ \\
\hline EU036210 & BBD120 & $\begin{array}{l}\text { Bos taurus beta-defensin } \\
120 \text { mRNA }\end{array}$ & 306.483 & $\mathrm{~N}$ & $\mathrm{Y}$ & $\mathrm{N}$ \\
\hline BC108218 & C29H11orf10 & $\begin{array}{l}\text { Chromosome } 11 \text { Open } \\
\text { Reading Frame } 10 \text { Ortholog }\end{array}$ & 297.346 & $\mathrm{~N}$ & $\mathrm{~N}$ & $\mathrm{~N}$ \\
\hline BC103170 & LOC781102 & $\begin{array}{l}\text { Eukaryotic Translation } \\
\text { Initiation Factor } 1\end{array}$ & 292.75 & $\mathrm{~N}$ & $\mathrm{~N}$ & $\mathrm{Y}$ \\
\hline BC142260 & taf10 & $\begin{array}{l}\text { Taf10 Rna Polymerase Ii, } \\
\text { Tata Box Binding Protein } \\
\text { (Tbp)-Associated Factor, } \\
\text { 30Kda }\end{array}$ & 289.583 & $\mathrm{~N}$ & $\mathrm{~N}$ & $\mathrm{Y}$ \\
\hline BC102743 & Tmco5a & $\begin{array}{l}\text { Transmembrane And } \\
\text { Coiled-Coil Domains 5A }\end{array}$ & 287.894 & $\mathrm{~N}$ & $\mathrm{~N}$ & $\mathrm{Y}$ \\
\hline BC108230 & SERF1A & $\begin{array}{l}\text { Small Edrk-Rich Factor 1B } \\
\text { (Centromeric) }\end{array}$ & 277.569 & $\mathrm{~N}$ & $\mathrm{~N}$ & $\mathrm{Y}$ \\
\hline AF058700 & LOC281370 & $\begin{array}{l}\text { Ubiquitin C; Polyubiquitin; } \\
\text { Ubiquitin A-52 Residue } \\
\text { Ribosomal Protein Fusion } \\
\text { Product } 1\end{array}$ & 277.039 & $\mathrm{Y}$ & Y & $\mathrm{Y}$ \\
\hline BC109684 & LOC540268 & Hypothetical Loc540268 & 272.881 & $\mathrm{Y}$ & $\mathrm{Y}$ & $\mathrm{Y}$ \\
\hline BC102675 & $D C U N 1 D 1$ & $\begin{array}{l}\text { Dcn1, Defective In Cullin } \\
\text { Neddylation 1, Domain } \\
\text { Containing } 1 \text { (S. Cerevisiae) }\end{array}$ & 269.749 & $\mathrm{Y}$ & $\mathrm{Y}$ & $\mathrm{Y}$ \\
\hline M19217 & Atp5j & $\begin{array}{l}\text { Atp Synthase, H+ } \\
\text { Transporting, Mitochondrial } \\
\text { F0 Complex, Subunit F6 }\end{array}$ & 269.601 & $\mathrm{Y}$ & $\mathrm{Y}$ & $\mathrm{Y}$ \\
\hline AY911383 & LOC786337 & Ribosomal Protein S24 & 267.359 & $\mathrm{~N}$ & $\mathrm{~N}$ & $\mathrm{Y}$ \\
\hline BC102168 & LOC781607 & Ribosomal Protein L36A & 262.035 & $\mathrm{~N}$ & $\mathrm{~N}$ & $\mathrm{Y}$ \\
\hline BC103196 & IMAGE:7986614 & $\begin{array}{l}\text { Bos taurus transcription } \\
\text { elongation factor B (SIII), } \\
\text { polypeptide } 2\end{array}$ & 261.222 & $\mathrm{~N}$ & $\mathrm{~N}$ & $\mathrm{Y}$ \\
\hline BC110154 & $M S 4 A 13$ & $\begin{array}{l}\text { Membrane-Spanning 4- } \\
\text { Domains, Subfamily A, } \\
\text { Member } 13\end{array}$ & 258.624 & $\mathrm{Y}$ & $\mathrm{Y}$ & $\mathrm{Y}$ \\
\hline BC151426 & LOC786258 & $\begin{array}{l}\text { Ran, Member Ras Oncogene } \\
\text { Family }\end{array}$ & 258.31 & $\mathrm{Y}$ & $\mathrm{Y}$ & $\mathrm{Y}$ \\
\hline $\mathrm{X} 15112$ & LOC614114 & $\begin{array}{l}\text { Cytochrome C Oxidase } \\
\text { Subunit Vib Pseudogene }\end{array}$ & 257.306 & $\mathrm{~N}$ & $\mathrm{~N}$ & $\mathrm{~N}$ \\
\hline BC109719 & SPINK2 & $\begin{array}{l}\text { Serine Peptidase Inhibitor, } \\
\text { Kazal Type } 2 \text { (Acrosin- } \\
\text { Trypsin Inhibitor) } \\
\text { Ubiquitin-Conjugating }\end{array}$ & 248.263 & $\mathrm{Y}$ & $\mathrm{Y}$ & $\mathrm{Y}$ \\
\hline ВT030506 & $U B E 2 N$ & $\begin{array}{l}\text { Enzyme E2N (Ubc13 } \\
\text { Homolog, Yeast) }\end{array}$ & 245.596 & $\mathrm{Y}$ & $\mathrm{Y}$ & $\mathrm{Y}$ \\
\hline EU036209 & BBD119 & $\begin{array}{l}\text { Bos taurus beta-defensin } \\
119 \text { mRNA }\end{array}$ & 244.782 & $\mathrm{Y}$ & $\mathrm{Y}$ & $\mathrm{Y}$ \\
\hline Z46789 & $C Y L C 2$ & $\begin{array}{l}\text { Cylicin, Basic Protein Of } \\
\text { Sperm Head Cytoskeleton } 2\end{array}$ & 243.523 & $\mathrm{Y}$ & $\mathrm{Y}$ & $\mathrm{Y}$ \\
\hline DQ347568 & LOC781571 & $\begin{array}{l}\text { Histidine Triad Nucleotide } \\
\text { Binding Protein 1; Similar } \\
\text { To Histidine Triad } \\
\text { Nucleotide-Binding Protein } \\
1\end{array}$ & 242.297 & $\mathrm{Y}$ & $\mathrm{Y}$ & $\mathrm{Y}$ \\
\hline BC102631 & LOC617040 & Similar To Hcg23722 & 241.208 & $\mathrm{~N}$ & $\mathrm{Y}$ & $\mathrm{N}$ \\
\hline AY911363 & LOC507141 & Ce5 Protein-Like & 241.165 & $\mathrm{Y}$ & $\mathrm{Y}$ & $\mathrm{Y}$ \\
\hline BC108150 & Selk & Selenoprotein K & 238.417 & $\mathrm{Y}$ & $\mathrm{Y}$ & $\mathrm{Y}$ \\
\hline BC102957 & $G P X 4$ & $\begin{array}{l}\text { Glutathione Peroxidase } 4 \\
\text { (Phospholipid } \\
\text { Hydroperoxidase) }\end{array}$ & 238.117 & $\mathrm{~N}$ & $\mathrm{~N}$ & $\mathrm{Y}$ \\
\hline BC149307 & LOC100125949 & $\begin{array}{l}\text { Similar To Iq Domain- } \\
\text { Containing Protein F1 }\end{array}$ & 235.802 & $\mathrm{Y}$ & $\mathrm{Y}$ & $\mathrm{Y}$ \\
\hline AB099097 & ORCS11619 & $\begin{array}{l}\text { Bos Taurus Mitochondrial } \\
\text { Rna, Similar To D-Loop }\end{array}$ & 235.006 & $\mathrm{Y}$ & $\mathrm{Y}$ & $\mathrm{Y}$ \\
\hline BC110123 & C16H1orf49 & Chromosome 1 Open & 234.333 & $\mathrm{Y}$ & $\mathrm{Y}$ & $\mathrm{Y}$ \\
\hline
\end{tabular}




\begin{tabular}{|c|c|c|c|c|c|c|}
\hline & & Reading Frame 49 Ortholog & & & & \\
\hline BC105361 & $L d h c$ & Lactate Dehydrogenase C & 230.203 & $\mathrm{Y}$ & $\mathrm{Y}$ & $\mathrm{Y}$ \\
\hline BC123583 & $A P 2 B 1$ & $\begin{array}{l}\text { Adaptor-Related Protein } \\
\text { Complex 2, Beta } 1 \text { Subunit }\end{array}$ & 228.35 & $\mathrm{~N}$ & $\mathrm{Y}$ & $\mathrm{Y}$ \\
\hline AY911358 & LOC781565 & Ribosomal Protein S6 & 227.299 & $\mathrm{Y}$ & $\mathrm{Y}$ & $\mathrm{Y}$ \\
\hline DQ347613 & $\operatorname{rps} 8$ & Ribosomal Protein S8 & 222.367 & $\mathrm{Y}$ & $\mathrm{Y}$ & $\mathrm{Y}$ \\
\hline AB098827 & LOC781379 & $\begin{array}{l}\text { Dynein, Light Chain, Lc8- } \\
\text { Type } 1\end{array}$ & 222.35 & $\mathrm{Y}$ & $\mathrm{Y}$ & $\mathrm{Y}$ \\
\hline DQ347611 & rps11 & $\begin{array}{l}\text { Ribosomal Protein S11 } \\
\text { Capping Protein (Actin }\end{array}$ & 221.749 & $\mathrm{Y}$ & $\mathrm{Y}$ & $\mathrm{Y}$ \\
\hline Y10372 & $C A P Z B$ & $\begin{array}{l}\text { Filament) Muscle Z-Line, } \\
\text { Beta }\end{array}$ & 220.387 & $\mathrm{Y}$ & $\mathrm{Y}$ & $\mathrm{Y}$ \\
\hline BC103401 & $\operatorname{clgn}$ & Calmegin & 220.011 & $\mathrm{Y}$ & $\mathrm{Y}$ & $\mathrm{Y}$ \\
\hline BC114181 & $D B I$ & $\begin{array}{l}\text { Diazepam Binding Inhibitor } \\
\text { (Gaba Receptor Modulator, } \\
\text { Acyl-Coenzyme A Binding } \\
\text { Protein) }\end{array}$ & 219.957 & $\mathrm{Y}$ & $\mathrm{Y}$ & $\mathrm{Y}$ \\
\hline M19962 & $C O X 5 B$ & $\begin{array}{l}\text { Cytochrome C Oxidase } \\
\text { Subunit Vb } \\
\text { Similar To Atp Synthase }\end{array}$ & 218.769 & $\mathrm{Y}$ & $\mathrm{Y}$ & $\mathrm{Y}$ \\
\hline X16978 & LOC782270 & $\begin{array}{l}\text { Subunit Epsilon, } \\
\text { Mitochondrial }\end{array}$ & 217.565 & $\mathrm{Y}$ & $\mathrm{Y}$ & $\mathrm{Y}$ \\
\hline BC108217 & Dynlrb2 & $\begin{array}{l}\text { Dynein, Light Chain, } \\
\text { Roadblock-Type } 2\end{array}$ & 215.832 & $\mathrm{~N}$ & $\mathrm{Y}$ & $\mathrm{N}$ \\
\hline BC102491 & LOC281370 & Polyubiquitin & 215.342 & $\mathrm{~N}$ & $\mathrm{Y}$ & $\mathrm{N}$ \\
\hline BC126796 & C23H6orf129 & $\begin{array}{l}\text { Chromosome } 6 \text { Open } \\
\text { Reading Frame } 129 \\
\text { Ortholog }\end{array}$ & 211.668 & $\mathrm{~N}$ & $\mathrm{Y}$ & $\mathrm{N}$ \\
\hline BC148017 & IMAGE:7946562 & $\begin{array}{l}\text { Bos taurus ribosomal } \\
\text { protein L37, mRNA }\end{array}$ & 208.936 & $\mathrm{Y}$ & $\mathrm{Y}$ & $\mathrm{Y}$ \\
\hline BC103060 & GABARAP & $\begin{array}{l}\text { Gaba(A) Receptor- } \\
\text { Associated Protein }\end{array}$ & 203.266 & $\mathrm{~N}$ & $\mathrm{~N}$ & $\mathrm{Y}$ \\
\hline BC126795 & $D E F B 123$ & Defensin, Beta 123 & 201.937 & $\mathrm{~N}$ & $\mathrm{Y}$ & $\mathrm{N}$ \\
\hline BC102751 & SPATA19 & $\begin{array}{l}\text { Spermatogenesis Associated } \\
19\end{array}$ & 201.143 & $\mathrm{Y}$ & $\mathrm{Y}$ & $\mathrm{Y}$ \\
\hline BC108162 & SEC62 & $\begin{array}{l}\text { Sec62 Homolog (S. } \\
\text { Cerevisiae) }\end{array}$ & 200.111 & $\mathrm{~N}$ & $\mathrm{~N}$ & $\mathrm{Y}$ \\
\hline BC108191 & C29H11orf67 & $\begin{array}{l}\text { Chromosome } 11 \text { Open } \\
\text { Reading Frame } 67 \text { Ortholog }\end{array}$ & 199.775 & $\mathrm{Y}$ & $\mathrm{Y}$ & $\mathrm{Y}$ \\
\hline AY835842 & $H 2 A F Z$ & $\begin{array}{l}\text { Bos taurus histone } \mathrm{H} 2 \mathrm{~A} \\
\text { mRNA }\end{array}$ & 197.567 & $\mathrm{~N}$ & $\mathrm{~N}$ & $\mathrm{~N}$ \\
\hline BC102469 & tmbim6 & $\begin{array}{l}\text { Transmembrane Bax } \\
\text { Inhibitor Motif Containing } 6 \\
\text { Guanine Nucleotide Binding }\end{array}$ & 196.512 & $\mathrm{~N}$ & $\mathrm{~N}$ & $\mathrm{Y}$ \\
\hline BC102286 & $G N B 2 L 1$ & $\begin{array}{l}\text { Protein (G Protein), Beta } \\
\text { Polypeptide 2-Like } 1\end{array}$ & 196.51 & $\mathrm{Y}$ & $\mathrm{Y}$ & $\mathrm{Y}$ \\
\hline BC120462 & tspan 5 & Tetraspanin 5 & 195.749 & $\mathrm{Y}$ & $\mathrm{Y}$ & $\mathrm{Y}$ \\
\hline BC108233 & polr $2 i$ & $\begin{array}{l}\text { Polymerase (Rna) Ii (Dna } \\
\text { Directed) Polypeptide I, } \\
14.5 \mathrm{Kda}\end{array}$ & 195.592 & $\mathrm{Y}$ & $\mathrm{Y}$ & $\mathrm{Y}$ \\
\hline BC103314 & LOC784243 & $\begin{array}{l}\text { Ribosomal Protein L34; } \\
\text { Similar To Ribosomal } \\
\text { Protein L34 }\end{array}$ & 195.156 & $\mathrm{Y}$ & $\mathrm{Y}$ & $\mathrm{Y}$ \\
\hline BC102445 & $R p L 30$ & Ribosomal Protein L30 & 195.066 & $\mathrm{~N}$ & $\mathrm{Y}$ & $\mathrm{N}$ \\
\hline BC114016 & $C c d c 54$ & $\begin{array}{l}\text { Coiled-Coil Domain } \\
\text { Containing } 54\end{array}$ & 194.483 & $\mathrm{Y}$ & $\mathrm{Y}$ & $\mathrm{Y}$ \\
\hline BC102549 & Ropn1 & $\begin{array}{l}\text { Ropporin, Rhophilin } \\
\text { Associated Protein } 1\end{array}$ & 193.878 & $\mathrm{~N}$ & $\mathrm{~N}$ & $\mathrm{Y}$ \\
\hline BC109557 & meig1 & $\begin{array}{l}\text { Meiosis Expressed Gene } 1 \\
\text { Homolog (Mouse) }\end{array}$ & 193.741 & $\mathrm{~N}$ & $\mathrm{~N}$ & $\mathrm{Y}$ \\
\hline BC111660 & LOC526524 & $\begin{array}{l}\text { Fk506 Binding Protein 1A, } \\
\text { 12Kda; Fk506 Binding } \\
\text { Protein 1A, 12Kda-Like }\end{array}$ & 193.185 & $\mathrm{Y}$ & $\mathrm{Y}$ & $\mathrm{Y}$ \\
\hline BC118480 & $S 100 G$ & $\begin{array}{l}\text { S100 Calcium Binding } \\
\text { Protein G }\end{array}$ & 192.026 & $\mathrm{Y}$ & $\mathrm{Y}$ & $\mathrm{Y}$ \\
\hline BC118372 & $S R P K 2$ & Sfrs Protein Kinase 2 & 190.687 & $\mathrm{~N}$ & $\mathrm{~N}$ & $\mathrm{Y}$ \\
\hline BC109867 & DDX25 & Dead (Asp-Glu-Ala-Asp) & 188.791 & $\mathrm{~N}$ & $\mathrm{~N}$ & $\mathrm{Y}$ \\
\hline
\end{tabular}


Box Polypeptide 25

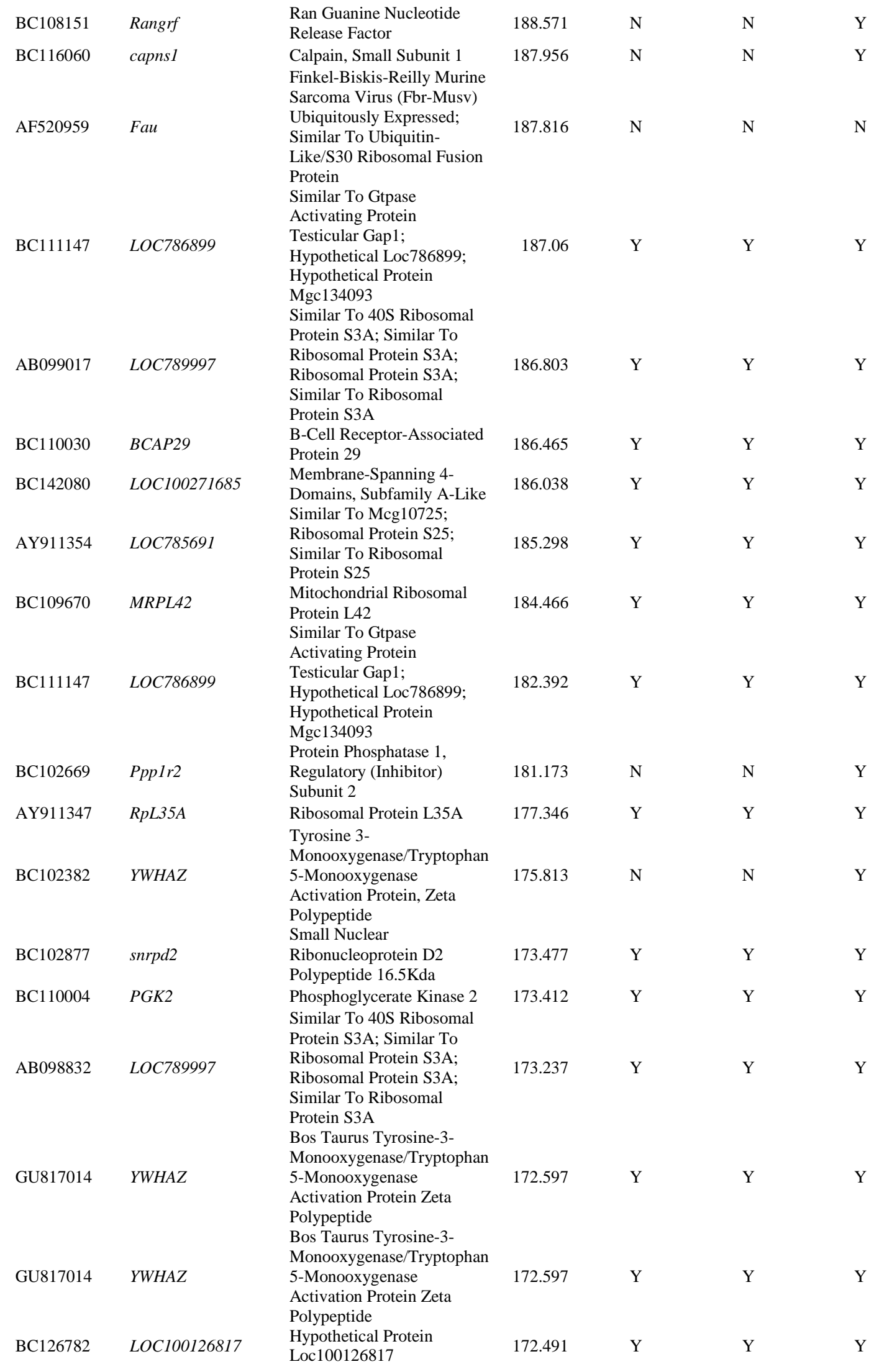




\begin{tabular}{|c|c|c|c|c|c|}
\hline DQ347605 & LOC782668 & Ribosomal Protein L6 & 171.318 & $\mathrm{Y}$ & $\mathrm{Y}$ \\
\hline BC105179 & rpl35 & Ribosomal Protein L35 & 170.04 & $\mathrm{~N}$ & $\mathrm{~N}$ \\
\hline BC111663 & LYRM7 & Lyrm7 Homolog (Mouse) & 168.54 & $\mathrm{Y}$ & $\mathrm{Y}$ \\
\hline BC102194 & EIF5 & $\begin{array}{l}\text { Eukaryotic Translation } \\
\text { Initiation Factor } 5\end{array}$ & 168.115 & $\mathrm{~N}$ & $\mathrm{~N}$ \\
\hline BC109743 & $H 2 A F Z$ & $\begin{array}{l}\text { H2A Histone Family, } \\
\text { Member Z }\end{array}$ & 166.742 & $\mathrm{~N}$ & $\mathrm{~N}$ \\
\hline BC118158 & IMAGE: 8211381 & $\begin{array}{l}\text { Bos taurus ST6 (alpha-N- } \\
\text { acetyl-neuraminyl-2,3-beta- } \\
\text { galactosyl-1,3)-N- } \\
\text { acetylgalactosaminide } \\
\text { alpha-2,6-sialyltransferase } \\
\text { 2, mRNA }\end{array}$ & 166.262 & Y & $\mathrm{Y}$ \\
\hline ВT025435 & C14orf153 & $\begin{array}{l}\text { Hypothetical Protein } \\
\text { Loc617441 }\end{array}$ & 165.939 & $\mathrm{~N}$ & $\mathrm{~N}$ \\
\hline BC108222 & IMAGE:8043996 & $\begin{array}{l}\text { Bos taurus cDNA clone } \\
\text { IMAGE: } 8043996\end{array}$ & 165.44 & $\mathrm{Y}$ & $\mathrm{Y}$ \\
\hline DQ677839 & C13H20ORF71 & $\begin{array}{l}\text { Chromosome } 20 \text { Open } \\
\text { Reading Frame } 71 \text { Ortholog }\end{array}$ & 165.204 & $\mathrm{Y}$ & $\mathrm{Y}$ \\
\hline BC108247 & SLIRP & $\begin{array}{l}\text { Sra Stem-Loop-Interacting } \\
\text { Rna-Binding Protein }\end{array}$ & 162.812 & $\mathrm{Y}$ & $\mathrm{Y}$ \\
\hline AB099059 & rps3 & Ribosomal Protein S3 & 162.118 & $\mathrm{Y}$ & $\mathrm{Y}$ \\
\hline BC102455 & LOC786431 & $\begin{array}{l}\text { Atp Synthase, H+ } \\
\text { Transporting, Mitochondrial } \\
\text { F0 Complex, Subunit G } \\
\text { Atpase, H+ Transporting, }\end{array}$ & 160.879 & $\mathrm{Y}$ & $\mathrm{Y}$ \\
\hline AB098994 & LOC784528 & $\begin{array}{l}\text { Lysosomal 34Kda, V1 } \\
\text { Subunit D }\end{array}$ & 160.731 & Y & $\mathrm{Y}$ \\
\hline BC102175 & C26H10orf84 & $\begin{array}{l}\text { Chromosome } 10 \text { Open } \\
\text { Reading Frame } 84 \text { Ortholog }\end{array}$ & 160.09 & Y & $\mathrm{Y}$ \\
\hline BC109561 & Rpl10l & Ribosomal Protein L10-Like & 159.931 & $\mathrm{~N}$ & $\mathrm{~N}$ \\
\hline BC109732 & IMAGE: 8059175 & $\begin{array}{l}\text { Bos taurus cDNA clone } \\
\text { IMAGE: } 8059175\end{array}$ & 159.464 & $\mathrm{Y}$ & $\mathrm{Y}$ \\
\hline BC111654 & $R p L 35 A$ & $\begin{array}{l}\text { Ribosomal Protein L35A } \\
\text { Similar To Ribosomal }\end{array}$ & 158.971 & $\mathrm{Y}$ & $\mathrm{Y}$ \\
\hline BC102313 & Rpl27 & $\begin{array}{l}\text { Protein L27; Ribosomal } \\
\text { Protein L27 }\end{array}$ & 158.242 & $\mathrm{~N}$ & $\mathrm{~N}$ \\
\hline BC105143 & LOC789244 & $\begin{array}{l}\text { Lysophospholipase I; } \\
\text { Similar To } \\
\text { Lysophospholipase I } \\
\text { Ribosomal Protein L10; }\end{array}$ & 157.322 & $\mathrm{~N}$ & Y \\
\hline DQ347607 & LOC509829 & $\begin{array}{l}\text { Ribosomal Protein L10 } \\
\text { Pseudogene; Similar To } \\
\text { Ribosomal Protein L10 }\end{array}$ & 157.248 & $\mathrm{~N}$ & $\mathrm{~N}$ \\
\hline BC102970 & hsbpl & $\begin{array}{l}\text { Heat Shock Factor Binding } \\
\text { Protein } 1\end{array}$ & 156.888 & $\mathrm{Y}$ & $\mathrm{Y}$ \\
\hline BC102292 & NDUFS4 & $\begin{array}{l}\text { Nadh Dehydrogenase } \\
\text { (Ubiquinone) Fe-S Protein } \\
\text { 4, 18Kda (Nadh-Coenzyme } \\
\text { Q Reductase) }\end{array}$ & 156.337 & $\mathrm{Y}$ & $\mathrm{Y}$ \\
\hline BC103431 & $E L P 2 P$ & $\begin{array}{l}\text { Endozepine-Like Peptide } 2 \\
\text { Pseudogene }\end{array}$ & 156.076 & $\mathrm{~N}$ & $\mathrm{~N}$ \\
\hline BC120463 & $M G C 151969$ & $\begin{array}{l}\text { Uncharacterized Protein } \\
\text { Ensp00000334415 Homolog }\end{array}$ & 156.043 & $\mathrm{~N}$ & $\mathrm{~N}$ \\
\hline AY911366 & rps11 & Ribosomal Protein S11 & 155.631 & $\mathrm{Y}$ & $\mathrm{Y}$ \\
\hline S70447 & GI:7579921 & $\begin{array}{l}\text { F1Fo-ATP synthase } \\
\text { complex Fo membrane } \\
\text { domain f subunit }\end{array}$ & 155.371 & $\mathrm{Y}$ & $\mathrm{Y}$ \\
\hline BC109581 & $D Y D C 1$ & $\begin{array}{l}\text { Dpy30 Domain Containing } \\
1\end{array}$ & 154.473 & $\mathrm{Y}$ & $\mathrm{Y}$ \\
\hline BC111293 & LOC780805 & $\begin{array}{l}\text { Hypothetical Protein } \\
\text { Loc780805 }\end{array}$ & 152.434 & $\mathrm{Y}$ & $\mathrm{Y}$ \\
\hline BC146140 & $D y d c 2$ & $\begin{array}{l}\text { Dpy30 Domain Containing } \\
2\end{array}$ & 152.001 & $\mathrm{~N}$ & $\mathrm{~N}$ \\
\hline DQ347605 & LOC782668 & Ribosomal Protein L6 & 151.466 & $\mathrm{Y}$ & $\mathrm{Y}$ \\
\hline AB098890 & ORCS10052 & $\begin{array}{l}\text { Bos Taurus Mrna For } \\
\text { Similar To Beta 2- } \\
\text { Microglobulin }\end{array}$ & 151.332 & $\mathrm{~N}$ & $\mathrm{~N}$ \\
\hline
\end{tabular}




\begin{tabular}{|c|c|c|c|c|c|c|}
\hline X64836 & NDUFB9 & $\begin{array}{l}\text { Nadh Dehydrogenase } \\
\text { (Ubiquinone) } 1 \text { Beta } \\
\text { Subcomplex, 9, 22Kda } \\
\text { Similar To Morf-Related }\end{array}$ & 149.949 & $\mathrm{Y}$ & $\mathrm{Y}$ & $\mathrm{Y}$ \\
\hline BC102593 & MORF4L1 & $\begin{array}{l}\text { Gene } 15 ; \text { Mortality Factor } 4 \\
\text { Like } 1\end{array}$ & 149.417 & $\mathrm{~N}$ & $\mathrm{~N}$ & $\mathrm{Y}$ \\
\hline BC109924 & Tspan6 & Tetraspanin 6 & 147.491 & $\mathrm{~N}$ & $\mathrm{Y}$ & $\mathrm{Y}$ \\
\hline BC103363 & KPNA2 & $\begin{array}{l}\text { Karyopherin Alpha } 2 \text { (Rag } \\
\text { Cohort 1, Importin Alpha 1) }\end{array}$ & 146.212 & $\mathrm{~N}$ & $\mathrm{~N}$ & $\mathrm{Y}$ \\
\hline DQ347612 & rps 12 & Ribosomal Protein S12 & 144.865 & $\mathrm{~N}$ & $\mathrm{~N}$ & $\mathrm{Y}$ \\
\hline BC103260 & $C A 2$ & Y Box Binding Protein 1 & 144.827 & $\mathrm{~N}$ & $\mathrm{~N}$ & $\mathrm{~N}$ \\
\hline BC109577 & Cetn4 & Centrin 4 & 144.395 & $\mathrm{Y}$ & $\mathrm{Y}$ & $\mathrm{Y}$ \\
\hline BC108180 & rps 21 & Ribosomal Protein S21 & 142.837 & $\mathrm{~N}$ & $\mathrm{Y}$ & $\mathrm{N}$ \\
\hline BC111609 & Iqcf2 & Iq Motif Containing F2 & 142.552 & $\mathrm{~N}$ & $\mathrm{~N}$ & $\mathrm{Y}$ \\
\hline BC102890 & Aifl & $\begin{array}{l}\text { Allograft Inflammatory } \\
\text { Factor } 1 \\
\text { Chromosome } 1 \text { Open }\end{array}$ & 141.932 & $\mathrm{~N}$ & $\mathrm{Y}$ & $\mathrm{N}$ \\
\hline BC109726 & C3H1orf189 & $\begin{array}{l}\text { Reading Frame } 189 \\
\text { Ortholog } \\
\text { Ferritin, Heavy Polypeptide }\end{array}$ & 141.298 & $\mathrm{Y}$ & $\mathrm{Y}$ & $\mathrm{Y}$ \\
\hline DQ347592 & LOC781370 & $\begin{array}{l}\text { 1; Similar To Ferritin Heavy } \\
\text { Chain; Similar To Ferritin, } \\
\text { Heavy Polypeptide } 1\end{array}$ & 140.117 & $\mathrm{Y}$ & Y & $\mathrm{Y}$ \\
\hline BC103298 & $C C T 2$ & $\begin{array}{l}\text { Chaperonin Containing } \\
\text { Tcp1, Subunit } 2 \text { (Beta) } \\
\text { Retinitis Pigmentosa Gtpase }\end{array}$ & 140.009 & $\mathrm{Y}$ & $\mathrm{Y}$ & $\mathrm{Y}$ \\
\hline AF265669 & RPGRIP1 & $\begin{array}{l}\text { Regulator Interacting } \\
\text { Protein } 1\end{array}$ & 139.66 & $\mathrm{~N}$ & $\mathrm{~N}$ & $\mathrm{Y}$ \\
\hline AF164025 & RNASE6 & $\begin{array}{l}\text { Ribonuclease, Rnase A } \\
\text { Family, K6 } \\
\text { Tubulin Polymerization- }\end{array}$ & 138.861 & $\mathrm{Y}$ & $\mathrm{Y}$ & $\mathrm{Y}$ \\
\hline BC102535 & TPPP2 & $\begin{array}{l}\text { Promoting Protein Family } \\
\text { Member } 2\end{array}$ & 138.018 & $\mathrm{~N}$ & $\mathrm{~N}$ & $\mathrm{Y}$ \\
\hline BC102655 & LRRC67 & $\begin{array}{l}\text { Leucine Rich Repeat } \\
\text { Containing } 67\end{array}$ & 137.872 & $\mathrm{Y}$ & $\mathrm{Y}$ & $\mathrm{Y}$ \\
\hline BC146224 & QTRTD1 & $\begin{array}{l}\text { Ribosyltransferase Domain } \\
\text { Containing } 1\end{array}$ & 137.523 & $\mathrm{~N}$ & $\mathrm{~N}$ & $\mathrm{~N}$ \\
\hline BC148911 & $T R D N$ & Triadin & 137.457 & $\mathrm{~N}$ & $\mathrm{~N}$ & $\mathrm{~N}$ \\
\hline BC111170 & C10H15orf 23 & $\begin{array}{l}\text { Chromosome } 15 \text { Open } \\
\text { Reading Frame } 23 \text { Ortholog }\end{array}$ & 137.17 & $\mathrm{~N}$ & $\mathrm{~N}$ & $\mathrm{Y}$ \\
\hline BC111202 & ilf 2 & $\begin{array}{l}\text { Interleukin Enhancer } \\
\text { Binding Factor 2, 45Kda }\end{array}$ & 136.727 & $\mathrm{~N}$ & $\mathrm{~N}$ & $\mathrm{Y}$ \\
\hline BC108198 & PRM3 & $\begin{array}{l}\text { Bos taurus protamine } 3 \text {, } \\
\text { mRNA }\end{array}$ & 136.117 & $\mathrm{~N}$ & $\mathrm{~N}$ & $\mathrm{~N}$ \\
\hline BC102492 & LOC616936 & Male-Enhanced Antigen 1 & 135.939 & $\mathrm{~N}$ & $\mathrm{~N}$ & $\mathrm{~N}$ \\
\hline BC102230 & Rnf181 & Ring Finger Protein 181 & 135.888 & $\mathrm{~N}$ & $\mathrm{~N}$ & $\mathrm{~N}$ \\
\hline BC102391 & $P S M C 2$ & $\begin{array}{l}\text { Proteasome (Prosome, } \\
\text { Macropain) 26S Subunit, } \\
\text { Atpase, } 2\end{array}$ & 135.115 & $\mathrm{~N}$ & $\mathrm{Y}$ & $\mathrm{N} \backslash$ \\
\hline BC103021 & LOC785297 & Ferritin, Light Polypeptide & 134.371 & $\mathrm{Y}$ & $\mathrm{Y}$ & $\mathrm{Y}$ \\
\hline BC110226 & C20orf111 & $\begin{array}{l}\text { Hypothetical Protein } \\
\text { Loc510457 } \\
\text { Similar To Thymosin, Beta }\end{array}$ & 134.345 & $\mathrm{~N}$ & $\mathrm{~N}$ & $\mathrm{Y}$ \\
\hline AY911377 & LOC785455 & $\begin{array}{l}\text { 4; Thymosin Beta } 4, X- \\
\text { Linked }\end{array}$ & 134.314 & $\mathrm{~N}$ & $\mathrm{~N}$ & $\mathrm{Y}$ \\
\hline BC111643 & IMAGE:8018076 & $\begin{array}{l}\text { Bos taurus cDNA clone } \\
\text { IMAGE: } 8018076\end{array}$ & 134.23 & $\mathrm{~N}$ & $\mathrm{~N}$ & $\mathrm{Y}$ \\
\hline BC140514 & CSDE1 & $\begin{array}{l}\text { Cold Shock Domain } \\
\text { Containing E1, Rna-Binding }\end{array}$ & 134.098 & $\mathrm{Y}$ & Y & $\mathrm{Y}$ \\
\hline BC102325 & $A R L 4 A$ & $\begin{array}{l}\text { Adp-Ribosylation Factor- } \\
\text { Like } 4 \text { A }\end{array}$ & 133.928 & $\mathrm{~N}$ & $\mathrm{~N}$ & $\mathrm{~N}$ \\
\hline AF013213 & LOC789867 & $\begin{array}{l}\text { Eukaryotic Translation } \\
\text { Elongation Factor } 1 \text { Alpha } 1\end{array}$ & 133.722 & $\mathrm{Y}$ & Y & $\mathrm{Y}$ \\
\hline BC119912 & C22H3ORF 19 & $\begin{array}{l}\text { Chromosome } 3 \text { Open } \\
\text { Reading Frame } 19 \text { Ortholog }\end{array}$ & 132.945 & $\mathrm{Y}$ & $\mathrm{Y}$ & $\mathrm{Y}$ \\
\hline BC114202 & SON & Son Dna Binding Protein & 132.028 & $\mathrm{Y}$ & $\mathrm{Y}$ & $\mathrm{Y}$ \\
\hline
\end{tabular}




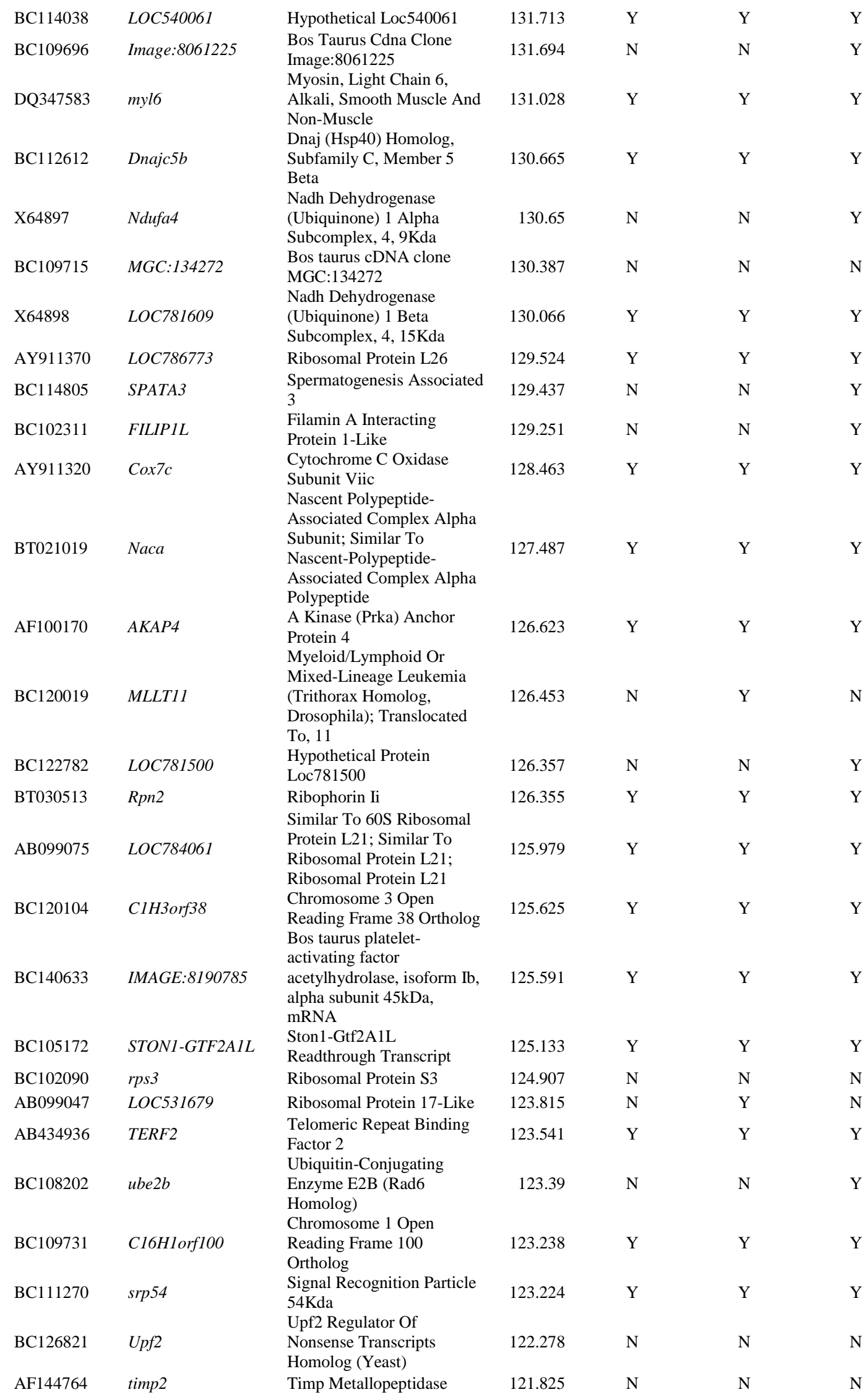


Inhibitor 2

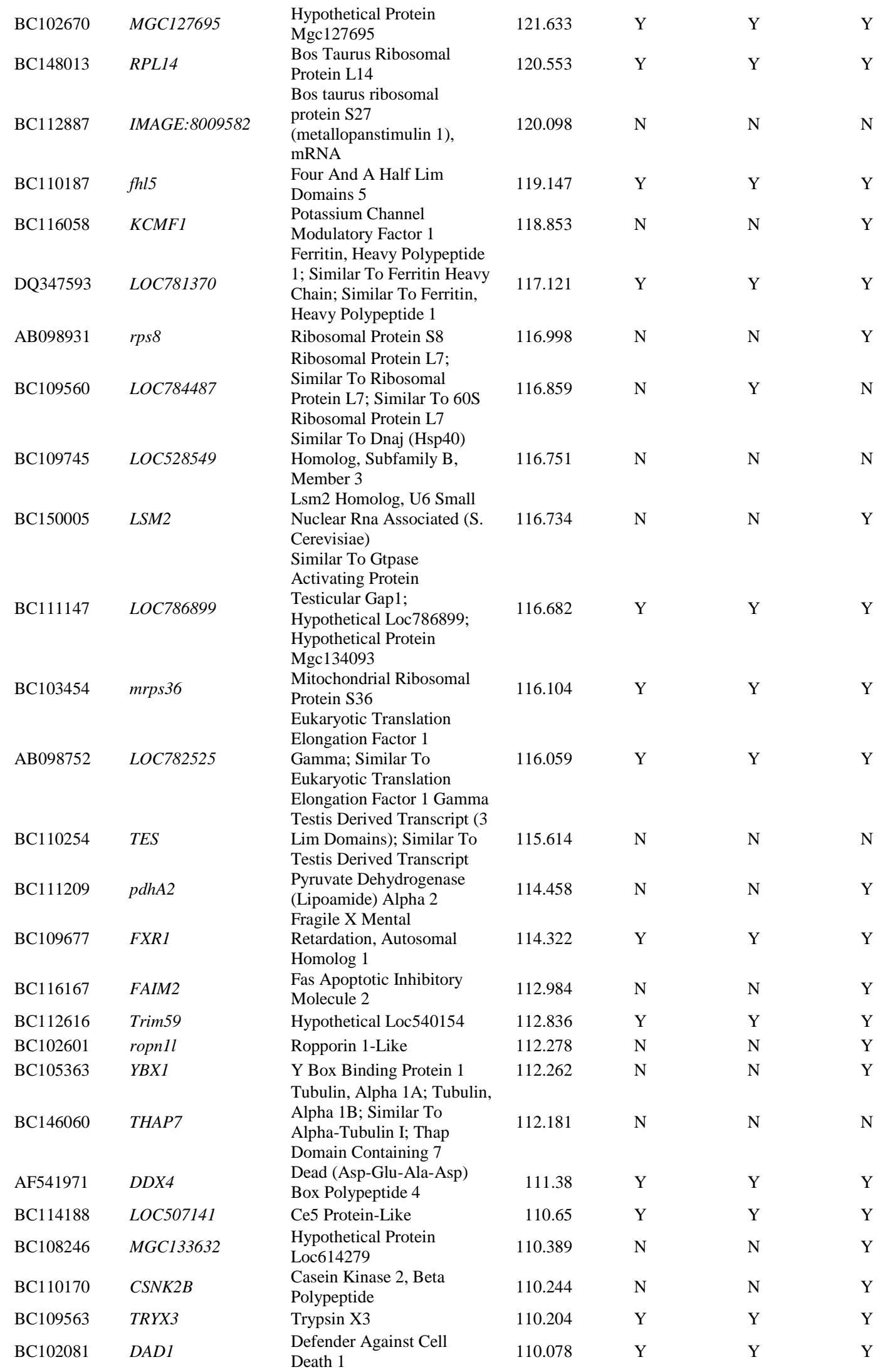




\begin{tabular}{|c|c|c|c|c|c|c|}
\hline X55389 & F1-ATPase & $\begin{array}{l}\text { mRNA for F1-ATPase } \\
\text { gamma-subunit }\end{array}$ & 110.066 & $\mathrm{~N}$ & $\mathrm{~N}$ & $\mathrm{Y}$ \\
\hline BC109599 & ADORA3 & $\begin{array}{l}\text { Adenosine A3 Receptor } \\
\text { Small Nuclear }\end{array}$ & 109.351 & $\mathrm{Y}$ & $\mathrm{Y}$ & $\mathrm{Y}$ \\
\hline BC102328 & SNRPB2 & $\begin{array}{l}\text { Ribonucleoprotein } \\
\text { Polypeptide B" }\end{array}$ & 109.087 & $\mathrm{~N}$ & $\mathrm{~N}$ & Y \\
\hline BC109851 & Asb17 & $\begin{array}{l}\text { Ankyrin Repeat And Socs } \\
\text { Box-Containing } 17\end{array}$ & 108.906 & $\mathrm{Y}$ & $\mathrm{Y}$ & $\mathrm{Y}$ \\
\hline BC108243 & NDUFA5 & $\begin{array}{l}\text { Nadh Dehydrogenase } \\
\text { (Ubiquinone) } 1 \text { Alpha } \\
\text { Subcomplex, 5, 13Kda }\end{array}$ & 108.605 & $\mathrm{Y}$ & $\mathrm{Y}$ & $\mathrm{Y}$ \\
\hline AY911358 & LOC781565 & Ribosomal Protein S6 & 108.563 & $\mathrm{Y}$ & $\mathrm{Y}$ & Y \\
\hline BC110237 & Mlec & $\begin{array}{l}\text { Malectin } \\
\text { Atp Synthase, } \mathrm{H}+\end{array}$ & 108.544 & $\mathrm{~N}$ & $\mathrm{~N}$ & $\mathrm{Y}$ \\
\hline BC110212 & LOC786673 & $\begin{array}{l}\text { Transporting, Mitochondrial } \\
\text { F0 Complex, Subunit B1 }\end{array}$ & 108.505 & $\mathrm{Y}$ & $\mathrm{Y}$ & $\mathrm{Y}$ \\
\hline BC109625 & Gkap1 & $\begin{array}{l}\text { G Kinase Anchoring Protein } \\
1\end{array}$ & 108.462 & $\mathrm{Y}$ & $\mathrm{Y}$ & $\mathrm{Y}$ \\
\hline BC140615 & $A D A M 3 A$ & $\begin{array}{l}\text { Adam Metallopeptidase } \\
\text { Domain 3A (Cyritestin 1) }\end{array}$ & 108.146 & $\mathrm{Y}$ & $\mathrm{Y}$ & $\mathrm{Y}$ \\
\hline BC102873 & Fau & $\begin{array}{l}\text { Finkel-Biskis-Reilly Murine } \\
\text { Sarcoma Virus (Fbr-Musv) } \\
\text { Ubiquitously Expressed; } \\
\text { Similar To Ubiquitin- } \\
\text { Like/S30 Ribosomal Fusion } \\
\text { Protein }\end{array}$ & 108.13 & $\mathrm{~N}$ & $\mathrm{~N}$ & $\mathrm{~N}$ \\
\hline BC102656 & IMAGE:30956887 & $\begin{array}{l}\text { Bos taurus pituitary tumor- } \\
\text { transforming } 1 \text {, mRNA } \\
\text { Cytochrome P450, Family }\end{array}$ & 107.717 & $\mathrm{Y}$ & $\mathrm{Y}$ & $\mathrm{Y}$ \\
\hline AB373012 & $C Y P 1 B 1$ & $\begin{array}{l}\text { 1, Subfamily B, Polypeptide } \\
1\end{array}$ & 107.159 & $\mathrm{Y}$ & $\mathrm{Y}$ & $\mathrm{Y}$ \\
\hline BC102135 & $B Z W 1$ & $\begin{array}{l}\text { Basic Leucine Zipper And } \\
\text { W2 Domains } 1 \\
\text { Similar To 14-3-3 Protein }\end{array}$ & 105.11 & $\mathrm{Y}$ & $\mathrm{Y}$ & $\mathrm{Y}$ \\
\hline ВТ030749 & LOC506261 & $\begin{array}{l}\text { Theta (14-3-3 Protein Tau) } \\
\text { (14-3-3 Protein T-Cell) } \\
\text { (Protein Hs1) }\end{array}$ & 105.009 & $\mathrm{~N}$ & $\mathrm{~N}$ & Y \\
\hline BC111628 & IMAGE:8019171 & $\begin{array}{l}\text { Bos taurus cDNA clone } \\
\text { IMAGE: } 8019171\end{array}$ & 104.983 & $\mathrm{Y}$ & $\mathrm{Y}$ & $\mathrm{Y}$ \\
\hline BC109721 & INSL6 & Bos taurus insulin-like 6 , & 104.965 & $\mathrm{~N}$ & $\mathrm{~N}$ & $\mathrm{Y}$ \\
\hline BC126695 & KLHL10 & Kelch-Like 10 (Drosophila) & 104.86 & $\mathrm{~N}$ & $\mathrm{~N}$ & $\mathrm{Y}$ \\
\hline BC112511 & $V T I 1 B$ & $\begin{array}{l}\text { Vesicle Transport Through } \\
\text { Interaction With T-Snares } \\
\text { Homolog 1B }\end{array}$ & 103.334 & $\mathrm{~N}$ & $\mathrm{~N}$ & Y \\
\hline BC102885 & Paip2 & $\begin{array}{l}\text { Poly(A) Binding Protein } \\
\text { Interacting Protein } 2\end{array}$ & 103.312 & $\mathrm{~N}$ & $\mathrm{~N}$ & $\mathrm{~N}$ \\
\hline AB098765 & FTH1 & $\begin{array}{l}\text { mRNA for similar to ferritin } \\
\text { H subunit }\end{array}$ & 103.092 & $\mathrm{~N}$ & $\mathrm{~N}$ & $\mathrm{Y}$ \\
\hline BC108215 & RTF1 & $\begin{array}{l}\text { Rtf1, Paf1/RNA polymerase } \\
\text { II complex component }\end{array}$ & 102.78 & $\mathrm{~N}$ & $\mathrm{~N}$ & $\mathrm{Y}$ \\
\hline BC111179 & $P S M G 2$ & $\begin{array}{l}\text { Proteasome (prosome, } \\
\text { macropain) assembly } \\
\text { chaperone } 2\end{array}$ & 102.639 & $\mathrm{~N}$ & $\mathrm{Y}$ & $\mathrm{N}$ \\
\hline BC133582 & cnot1 & $\begin{array}{l}\text { Ccr4-Not Transcription } \\
\text { Complex, Subunit } 1\end{array}$ & 102.582 & $\mathrm{Y}$ & $\mathrm{Y}$ & $\mathrm{Y}$ \\
\hline BC109747 & Hemgn & Hemogen & 102.453 & $\mathrm{Y}$ & $\mathrm{Y}$ & $\mathrm{Y}$ \\
\hline AB098753 & LOC781609 & $\begin{array}{l}\text { Similar To B15 Subunit Of } \\
\text { The NADH }\end{array}$ & 102.178 & $\mathrm{Y}$ & $\mathrm{Y}$ & $\mathrm{Y}$ \\
\hline BC102499 & naa38 & $\begin{array}{l}\text { Lsm8 Homolog, U6 Small } \\
\text { Nuclear Rna Associated (S. } \\
\text { Cerevisiae) }\end{array}$ & 100.954 & $\mathrm{~N}$ & $\mathrm{~N}$ & Y \\
\hline BC109698 & FUNDC2 & FUN14 domain containing 2 & 100.902 & $\mathrm{~N}$ & $\mathrm{~N}$ & Y \\
\hline HQ423186 & BBD126 & $\begin{array}{l}\text { Bos Taurus Beta-Defensin } \\
126 \text { Mrna }\end{array}$ & 100.859 & $\mathrm{Y}$ & $\mathrm{Y}$ & $\mathrm{Y}$ \\
\hline AF307320 & RPS28 & $\begin{array}{l}\text { ribosomal protein S28-like } \\
\text { protein mRNA }\end{array}$ & 100.799 & $\mathrm{~N}$ & $\mathrm{~N}$ & $\mathrm{~N}$ \\
\hline BC109495 & WDR61 & WD repeat domain 61 & 100.679 & $\mathrm{~N}$ & $\mathrm{~N}$ & $\mathrm{Y}$ \\
\hline BC102453 & STMN1 & Stathmin 1/oncoprotein 18 & 100.645 & $\mathrm{~N}$ & $\mathrm{~N}$ & $\mathrm{Y}$ \\
\hline
\end{tabular}


$\begin{array}{ll}\mathrm{BC} 126794 & \text { LYZL1 } \\ \mathrm{BC} 112727 & C C D C 91\end{array}$

BC112727 CCDC91
Lysozyme-Like 2

Coiled-coil domain

containing 91

100.291

100.177
Y

Y

Y 


\title{
CHAPTER 3: MOLECULAR REPRODUCTION AND DEVELOPMENT
}

\section{MANUSCRIPT}

Title: Are full-length mRNA in Bos taurus spermatozoa transferred to the oocyte during fertilization?

Authors: Anderson $\mathrm{EJ}^{1}$, Card $^{1}$, Sartini BL ${ }^{1,3}$

${ }^{1}$ Department of Fisheries, Animal and Veterinary Science, University of Rhode Island, Kingston, Rhode Island 02881

${ }^{3}$ Corresponding author: BL Sartini, 179 Center for Biotechnology and Life Sciences, 120 Flagg Road, University of Rhode Island, Kingston, RI 02886, Phone: 401-8742667, FAX: 401-874-7575, Email: blsartini@uri.edu.

Institution at which work was performed: University of Rhode Island, Kingston, RI

Short Title: Full-Length mRNA in Bull Spermatozoa

Key Words (3-6): Spermatozoa, full-length, mRNA

\begin{abstract}
Abbreviations: $\mathrm{mRNA}=$ messenger RNA; FPKM $=$ Fragments Per per Kilobase of transcript per Million mapped reads; RNA-Seq = ribonucleic acid sequencing; rRNA $=$ ribosomal ribonucleic acid; $\mathrm{CR}=$ conception rate; $\mathrm{PCR}=$ polymerase chain reaction; UTR $=$ untranslated region
\end{abstract}


Grant Support: This project was supported by an Agriculture and Food Research Initiative Competitive Grant no. 2011-67016-20073 from the USDA National Institute of Food and Agriculture to BLS. This research is based in part upon work conducted using the Rhode Island Genomics and Sequencing Center which is supported in part by the National Science Foundation under EPSCoR Grants Nos. 0554548 \& EPS1004057. 


\section{Abstract:}

Spermatozoa are now known to contain a limited number of mRNAs and the contribution of these mRNAs to early embryonic development has been controversial. Although the spermatozoal transcript profile contains a predominance of degraded transcripts, only full-length mRNA transcripts will be capable of producing a protein after the spermatozoa fertilize the oocyte and the presence of full-length spermatozoal transcripts has not been investigated. This study sequenced 24 spermatozoal transcripts, chosen using four techniques: high FPKM within an RNA-Seq dataset, Gene Ontology of the RNA-Seq dataset, Y chromosome specificity, and transcripts discovered from previous studies, to determine if full-length transcripts exist in spermatozoa. Of these transcripts, 16 were full-length, while 8 are degraded. Additionally, four transcripts, PSMA6, ATPase $\beta$, CHMP5, and DDX3Y, have alternative polyadenylation sites, which the referenced RNA-Seq study failed to identify. To further characterize the potential functionality of these transcripts, the transfer of spermatozoal transcripts to oocytes and 2-cell stage embryos was examined. However, recurrent contamination and conflicting results from the oocyte and 2-cell embryos occurred. Despite this, the 16 transcripts that have been found to be full-length in spermatozoa do merit further investigation, and prove that while many transcripts are degraded remnants from spermatogenesis, full-length mRNAs, with the potential to be a functional protein, are found in spermatozoa. 


\section{Introduction:}

Recent research has shown that spermatozoa contain not only genomic DNA, but also a subset of mRNA (Lalancette et al. 2008; Avendaño et al. 2009; Johnson et al. 2011; Card et al. 2013). Although spermatozoa are not transcriptionally or translationally active, they still contain mRNAs present from the final surge of transcriptional activity at the end of spermatogenesis (Miller and Ostermeier 2006; Boerke et al. 2007). Many of the transcripts found in spermatozoa are degraded (Gilbert et al. 2007), although functional roles of spermatozoa mRNAs have been proposed, including functions in early embryo development regulation, epigenetic modifications, paternal genome maintenance, and structural functions (Lalancette and Miller 2008). Spermatozoal mRNAs are likely most important prior to the transition from maternal to zygotic gene expression, since this is when they are most capable of affecting gene expression and epigenetic regulation. In cows, a transcriptional burst occurs at the eight to sixteen-cell embryonic stage, when zygotic control of mRNA expression begins (Vigneault et al. 2009). This activation occurs approximately 62 hours after fertilization, so any transcripts carried by the spermatozoa provide an advantage since there is little time for transcription and translation to occur before the zygote takes control of the mRNA expression (Memili and First 2000).

A role for sperm-derived RNAs after fertilization is supported by a functional role for microRNA-34c during the first cleavage of mouse embryos (Liu et al. 2012). Micro-RNAs may also have an epigenetic impact on the embryo (Carrell and Hammoud 2010). To date, $P L C$ - $\zeta$ is the only sperm-derived mRNA with a known

function in the oocyte after fertilization. $P L C$ - $\zeta$ triggers the $\mathrm{Ca}^{2+}$ oscillations during 
oocyte activation (Swann et al. 2006; Hamatani 2012), and may also have a role in embryo cell-signaling (Boerke et al. 2007).

Limited studies have demonstrated that other spermatozoal transcripts can be detected in embryos, but are not present in oocytes, including AKAP 4, CLGN, CLU, DDX3Y, PLC-ร, PRM1, PRM2 SPAG9, and SRY (Suri 2004; Boerke et al. 2007;

Kempisty et al. 2008b). Of particular interest to this study are genes that are spermatozoa-specific, as they will be most useful for downstream protein identification in the embryo. The use of Y-chromosome specific transcripts allows for definitive identification of heritage of the transcript from the spermatozoa, an example transcript is DDX3Y (Sekiguchi et al. 2004; Vong et al. 2006; Bermejo-Alvarez et al. 2010; Yao et al. 2010a; Yao et al. 2010b). DDX3Y, a DEAD-box RNA helicase that can change RNA secondary structure, is sperm-derived but found in the embryo at fertilization (Yao et al. 2010a). A reduction in sperm-derived DDX3Y mRNA decreases embryonic development rates therefore a role for sperm-derived $D D X 3 Y$ in early embryogenesis has been proposed (Abdelhaleem 2005; Yao et al. 2010b).

However, previous research has identified individual spermatozoal transcripts primarily using microarrays that detect only a small segment of a transcript and cannot determine if a full-length transcript is present. Although a large proportion of spermatozoal transcripts are degraded, but they may still be used as predictors of bull fertility (Gilbert et al. 2007; Bissonnette et al. 2009). No previous research has investigated if spermatozoal mRNAs are full-length, including the coding region and untranslated regions, despite the fact that incomplete mRNAs will be incapable of producing proteins used in embryo development. Identifying full-length transcripts 
may allow further studies to elucidate if these transcripts have a functional role in the embryo or are degraded in the embryo.

We hypothesize that full-length mRNAs are present in spermatozoa and some may be transferred to the oocyte and detected in the early embryo after fertilization. In this study, candidate spermatozoal transcripts were identified from the transcript profile of bull spermatozoa sequenced by RNA-Seq (Card et al. 2013). Transcripts were identified using four techniques: 1)if they had high FPKMs in the RNA-Seq dataset, 2) found in Gene Ontology (GO) categories of interest, 3) located on the Y chromosome, or 4) present in previous literature. With RNA-Seq, potential full-length transcripts can be identified by alignment of sequenced fragments to the bovine genome. Potentially functional spermatozoal transcripts were also identified by comparing microarray data from oocyte and embryo studies (Kocabas et al. 2006; Chalmel et al. 2007; Huang and Khatib 2010).

Additionally, this work highlights some specific examples of alternative 3' ends for transcripts that are found in spermatozoa, and provides quantitative percent coverage of several transcripts. Identification of full-length spermatozoal transcripts that are transferred to the oocyte at fertilization could be used in further functional studies. 


\section{Materials and Methods:}

\section{Spermatozoal transcript selection}

Four approaches were used to identify select candidate bovine spermatozoal transcripts for further analysis to determine if these transcripts are full-length in spermatozoa and if these transcripts are transferred to the oocyte at fertilization (Table

1). The first three approaches mined the bovine spermatozoa transcript profile (Card et al. 2013) and the same pool of bovine spermatozoa from nine bulls was used in both studies to validate full-length transcripts. In the first approach, we identified nine spermatozoal transcripts with high FPKMs (fragments per kilobase million mapped reads) in the bovine spermatozoal transcript profile (Card et al. 2013). In the second approach, we identified transcripts in the top Gene Ontology (GO) category, translation (Card et al. 2013). Third, Y chromosome specific transcripts in the bovine spermatozoal transcript profile were identified because it is a definitive way to prove that the transcript was sperm-derived in embryo. Finally, thirteen potentially functional spermatozoal transcripts from previous studies were confirmed present the bovine spermatozoa transcript profile.

To determine if any of the selected transcripts were potentially transferred to the oocyte by the spermatozoa, previous microarray studies were used to find transcripts that were previously present in spermatozoa (Chalmel et al. 2007) but absent in the oocyte (Kocabas et al. 2006).

\section{Tissue Samples}

Bovine testes were collected from a local abatoir for RNA isolation. Bovine cumulus-free oocytes and two-cell stage embryos were obtained from Sexing 
Technologies (Navasota, TX). Cryopreserved bovine spermatozoa straws were obtained from Genex Cooperative Inc., (Shawano, WI). Spermatozoa from nine individual bulls was pooled after RNA isolation (see below) for cDNA amplification. These individuals had Conception Rate (CR) scores ranging from -2.9 to 3.5. Spermatozoa from an additional three bulls were used for mRNA Reverse Transcription (RT) for use in 5' and 3' Rapid Amplification of cDNA Ends (RACE) protocols. The three bull spermatozoa pool has CR scores of $-0.3,1.3$, and -4 .

\section{Tissue RNA Isolations}

RNA was isolated from bovine testis and spermatozoa using TRIzol isolation (Sigma-Aldritch; St. Louis, MO). Testis RNA isolations were performed according to manufacturer's instructions, using $100 \mathrm{mg}$ of tissue per isolation.

Spermatozoa TRIzol isolations were modified from the kit protocol as described in Card and Anderson et al. 2013. After washing spermatozoa with PBS (Phosphate Buffered Saline) to remove the cryoprotectant, $1 \mathrm{~mL}$ TRIzol with 15 $\mu \mathrm{g} / \mathrm{mL}$ glycogen was added to the sperm. Samples were then lysed using a $26 \mathrm{~g}$ needle and incubated at room temperature for thirty minutes. Then chloroform was added and incubated for 10 minutes at room temperature. Phase separation was done at $12000 \times \mathrm{g}$ for 15 minutes at $4^{\circ} \mathrm{C}$. The aqueous layer was removed, combined with 500 $\mu \mathrm{L}$ ice-cold isopropanol, and chilled on ice for 10 minutes. After a $12000 \mathrm{xg}$ centrifugation for 10 minutes, , the precipitated pellet washed with $1 \mathrm{~mL} 75 \%$ ethanol and centrifuged for an additional 10 minutes. Supernatant was removed, and pellet was air dried. The pellet of RNA was then resuspended in nuclease free water. RNA samples were DNAse treated using the RNeasy Mini Kit (Qiagen, Valencia, CA), and 
RNA concentrations were measured using the NanoDrop UV/Vis spectrometer (Thermo Scientific; Wilmington, DE). Samples were then stored at $-80^{\circ} \mathrm{C}$.

Bovine oocyte and 2-cell stage embryo RNA isolations were performed according to manufacturer's instructions, using the PicoPure RNA isolation kit (Arcturus, Mountain View, CA), with 40 oocytes or embryos used per isolation. RACE Reverse Transcription and Polymerase Chain Reaction (RACE RT-PCR)

RACE RT-PCR was used for amplification of 5' and 3' ends of transcripts, using the three bull spermatozoa pool. For transcripts $<1200 \mathrm{bp}$, the full-length transcripts was amplified using this technique. RT-PCR 5' and 3' RACE protocols were performed according to manufacturer's instructions (Invitrogen, Carlsbad, CA), using a Gene Specific Primer (GSP) (Table 2) paired with a Generacer 5' or 3' universal primer for improved amplification of the poly(A) tail and 5' Untranslated Region (UTR). Transcripts that were $<1200$ base pairs were amplified using primers spanning from the 5' exon to the 3' exon, with a 5' RACE and a 3'RACE PCR run in conjunction to amplify all areas as necessary. For transcripts with $>1200$ base pairs, overlapping amplicons were used to cover the entirety of the transcript.

Primers were designed for use with 5' and 3' RACE RT-PCRs to amplify ends of transcripts. Additional primer sets for each transcript of interest were designed to provide overlapping amplicons for sequencing of the midsection of each transcript, and when transcripts were larger than 1200 base pairs, additional standard RT-PCRs (discussed below) were used to amplify regions spanning the exons from the 5' end to the 3' end. Each primer set was tested on testis RNA as a positive control. Additionally, a negative control lacking template was run in parallel. 
cDNA Amplification \& Standard RT-PCR

Due to low yield from spermatozoa RNA isolations, amplified ds-cDNA from a nine bull pool was used for PCR for transcripts with >1200 bp. RNA was converted to ds-cDNA and amplified before use in PCR reactions (SMARTer Pico PCR cDNA Synthesis Kit; Clontech, Mountain View, CA). The cDNA amplification enriches for full-length mRNA populations by using a modified oligo(dT) primer. All PCRs were run for 26 cycles to optimize them to reach the linear phase. Each of the nine bulls was equally represented in the final pooled sample. PCRs were performed under standard conditions as follows: $1 \mathrm{X}$ reaction buffer, $1.5 \mathrm{mM} \mathrm{MgCl} 2,10 \mathrm{mM}$ dNTPs, $2.5 \mu \mathrm{M}$ forward and reverse primers (Table 2), and 2.5 U Taq polymerase (NEB, Ipswich, MA). PCRs were run under standard temperatures of: $94^{\circ} \mathrm{C}$ for 5 min, 35 cycles of $94^{\circ} \mathrm{C}$ for $30 \mathrm{sec}$, primer dependent annealing temperature for $30 \mathrm{sec}$ then $72^{\circ} \mathrm{C}$ for 2 min followed by a final extension at $72^{\circ} \mathrm{C}$ for $10 \mathrm{~min}$. All PCRs were run with a positive Testis RNA control and a negative control without template RNA.

Oocytes and two cell stage embryos were amplified in two separate sets. The first set was cDNA amplified into ds-cDNA using the SMARTer Pico PCR cDNA Synthesis Kit (Clontech, Mountain View, CA). The second set was performed using the standard RT-PCR conditions described above. All RT-PCRs were run with a positive testis control and a negative no template RNA control.

\section{$\underline{\text { Agarose Gels \& Sequencing }}$}

PCR products were visualized on a $2.0 \%$ agarose gel stained with ethidium bromide, and run by gel electrophoresis. Bands excised from the gel were gel purified (Qiagen Gel Extraction kit; Valencia, CA), and submitted for sequencing at the URI 
Genomics Center (Kingston, RI). Amplicon sequence identity was confirmed by submission to NCBI BLAST and by alignment to the original transcript accession the primers were designed from. 


\section{Results:}

Twenty-four spermatozoal transcripts were chosen for this study from previous spermatozoal transcript studies, a spermatozoal RNA-Seq dataset, and for their male specificity (Table 1). Transcripts were chosen if visual inspection of the RNA-Seq read mappings using the UCSC browser showed that exons were present in the RNASeq analysis (Figure 1; Meyer et al. 2013). Only two transcripts were selected using the Gene Ontology selection method from the translation category, EEFIG and EEF1A1. Additional transcripts that did not show complete exon mapping were also chosen for analysis if previous studies had hypothesized a function for these transcripts including the $\mathrm{Y}$ chromosome transcript, $D D X 3 Y$. DDX3Y was the only $\mathrm{Y}$ chromosome spermatozoa transcript identified. This is not entirely unexpected, as the Y-chromosome contains only 33 genes in total (Yao et al. 2010b).

Of the selected candidate spermatozoal transcripts examined, the full-length of 16 spermatozoal transcripts were PCR amplified for the genes CCT8, $H 2 A F Z$, COX7A2, CRISP2, EEF1A1, EEF1G, GSTM3, PLCZ1, PRM1, PSMA1, HMGB4, GTSF1, CKS2, PSMA6, SEC61G, and CMYC (Figure 2). Transcripts were considered to be full-length when they contained greater than $90 \%$ sequencing coverage, although the transcripts CCT8, COX7A2, CRISP2, EEF1A1, EEF1G, GSTM3, PRM1, and PSMA1 have been $100 \%$ sequenced (Table 3A).

Eight additional transcripts could not be sequenced in entirety, most likely because they are degraded in spermatozoa (Figure 1B). These eight transcripts found in the bovine spermatozoal transcript RNA-Seq data had similar missing regions in PCR amplifications (Figure 3; Table 3). An example of this is the transcript PEBP1, 
which had read mappings missing from the 5' end exon entirely; corresponding to missing reads found using PCR amplification (Figure 1). Five transcripts, PEBP1, ATPase B, CHMP5, UBE2N, and DDX3Y, were found to be non-full-length in both the RNA-Seq data and in PCR identification.

A distinguishing characteristic that was found when sequencing full-length transcripts was evidence of alternative 3' untranslated regions (UTRs) in novel locations to previous accessions. Although accessions for mRNA transcripts may be labeled for a single gene, there may be multiple isoforms or variants of a transcript that exist. Four transcripts, PSMA6, ATPase $\beta, C H M P 5$, and $D D X 3 Y$, had alternative 3' UTRs (Figures 1 and 2; Table 3). These transcripts were degraded, with the exception of PSMA6, which was shown to be full-length.

The transcripts chosen for amplification in oocytes and 2-cell stage embryos were identified as transferred to the embryo from spermatozoa in a different species or because these transcripts were not present in microarray studies of oocytes (Ostermeier et al. 2004; Kocabas et al. 2006; Chalmel et al. 2007; Kempisty et al. 2008a). Transcripts found to be present in oocytes from previous microarray data were eliminated for further analysis, since PCR will be incapable of distinguishing the origin of the mRNAs in the zygote (Table 4). This left nine transcripts to investigate further that were absent in the oocyte microarray data: $A K A P 4, C L G N, C M Y C$, CRISP2, DDX3Y, HMGB4, PLCZ1, PRM1, and SPA17.

Contamination and conflicting results from PCR amplification of spermatozoal transcripts in oocytes and 2-cell embryos have yielded inconclusive results. Two replicates of oocytes and 2-cell embryos pools, one cDNA amplified and one 
unamplified RNA, have demonstrated amplification of male-specific transcripts in female tissue, for example $D D X 3 Y$ and $P R M 1$ (Figure 4).

\section{Discussion:}

Visual inspection of RNA-Seq reads mapped to the bovine genome from the bovine spermatozoa transcript profile was used to identify sixteen full-length transcripts and these were validated by PCR amplification and subsequent sequencing, proving that these transcripts have the basic potential for use downstream in the early stage embryo. These results validate RNA-Seq read mappings by directly sequencing the 5' and 3' UTRs in addition to the complete protein coding region of these transcripts. Importantly, PCR sequencing is capable of identifying transcripts that have been alternatively polyadenylated, which may impact the timing of translation, while RNA-Seq cannot. Additionally, if multiple isoforms of a transcript are present, they can be detected through PCR more accurately than with RNA-Seq. Studies of this nature that use both RNA-Seq and PCRs may prove useful as prerequisite identification of targets for determining if these transcripts are translated into protein in the embryo.

While other studies have looked at the mRNAs contained in spermatozoa, this is the first study to identify full-length transcripts. The importance of this is noted by the fact that this study found transcripts of interest from previous literature (Table 1) that are not full-length (Table 3), and therefore likely non-functional. An example of this is $D D X 3 Y$, which has been examined in previous studies. One study found that reduction in sperm-derived $D D X 3 Y$ mRNA has a role in spermatogenesis (Abdelhaleem 2005). A second study found that $D D X 3 Y$ was transferred from mouse 
spermatozoa to the oocyte and that it's absence decreases embryo development rates (Yao et al. 2010a). Although these previous studies point to a role for $D D X 3 Y$, it was degraded in the spermatozoa transcript population reported here and therefore could not be functional as a translational template in the embryo. The mRNA transcript $A K A P 4$ which was found to be degraded in this studies transcript profile correlates with its known function as a regulator of spermatozoa motility (Miki et al. 2002). However, the use of these degraded transcripts may still serve as indicators of fertility, despite knowing that a particular degraded transcript will not have a functional use in the oocyte (Lalancette et al. 2008).

The transcripts found to be full-length in this study will be useful candidates for examination of protein function in future studies to determine if sperm-derived mRNA does have a functional role in early embryogenesis. Spermatozoal mRNAs are likely most important prior to the transition from maternal to zygotic gene expression, since this is when they are most capable of affecting gene expression and epigenetic regulation. In cows, a transcriptional burst occurs at the eight to sixteen-cell stage, when zygotic control of mRNA expression begins (Vigneault et al. 2009). This activation occurs around 62 hours after fertilization, so any transcripts carried by the spermatozoa provide an advantage since there is little time for transcription and translation to occur before the zygote takes control of the mRNA expression (Memili and First 2000). To date, the only full-length spermatozoal transcript known to have an embryonic function is $P L C$ - $\zeta . P L C$ - $\zeta$ triggers the $\mathrm{Ca}^{2+}$ oscillations during mouse oocyte activation and may have a role in embryo cell-signaling (Swann et al. 2006; Boerke et al. 2007; Hamatani 2012). This study was able to demonstrate that PLC- $\zeta$ 
is full-length, although it is unable to confirm that $P L C$ - $\zeta$ is delivered to the oocyte during bovine fertilization.

Other full-length spermatozoal transcripts that were identified in this study are known to rapidly degrade after entering the oocyte, including $P R M 1$, indicating no further functionality within the embryo (Avendaño et al. 2009; Thelie et al. 2009). Furthermore, this study does not indicate the degree of degradation that might occur to the spermatozoal transcripts once they reach the oocyte. To further explore how much degradation occurs and when it occurs, future studies will need to explore oocytes and embryos to trace the inheritance of these spermatozoal mRNAs.

Full-length spermatozoal transcripts were sequenced that warrant further functional experiments. For example, CRISP2 may assist with spermatozoa survival in the female tract and fertilization (Arangasamy et al. 2011). Preliminary reports of translation occurring in the spermatozoa mitochondria may indicate a need to replace proteins necessary for fertilization, as this translation occurs in the spermatozoa tailpiece right after the spermatozoa undergo capacitation (Gur and Breitbart 2008).

An additional hypothesized function of spermatozoal mRNA is an epigenomic effect on embryonic development. Although the degree of epigenetic influence that the spermatozoal mRNAs exhibit is unknown, genes such as $P R M I$ and $H 2 A F Z$ have been shown to have an influence on the epigenome (Jenkins and Carrell 2012). Specifically, sperm-specific $P R M 1$ proteins replace histones in spermatozoa chromatin, regulating how development proceeds (Carrell and Hammoud 2010). PRMI may act to selectively unwind specific regions of the paternal DNA to make it more accessible for transcription and translation in the early embryo before being degraded (Miller et al. 
2005). The transcript $H 2 A F Z$ is an effector of gene regulation as well by acting as a histone modifier (Misirlioglu et al. 2006). By demonstrating that PRMI and H2AFZ are full-length in spermatozoa, this study demonstrates the potential for spermatozoa to have an epigenetic effect on embryonic development.

However, it is important to highlight the inherent bias to these selection methods, with a clear focus on isolating genes with a high probability of being fulllength. This study cannot be used to comment on the percentage of transcripts that may be full-length in the spermatozoa, only to prove that some do exist.

This study is incapable of determining if full-length spermatozoal transcripts are transferred to the oocyte at fertilization. The attempted oocyte and 2-cell embryo PCRs yielded inconclusive results. Several suspect amplifications indicated that the oocytes and 2-cell embryos were likely contaminated in both the cDNA amplified and unamplified RNA experiments (Figure 4). The presence of known sperm-specific transcripts and $\mathrm{Y}$ chromosome transcripts in these populations, as well as varying results from gel to gel (Figure 4), make it impossible to conclude more about the spermatozoa to oocyte inheritance of these transcripts at this time.

In conclusion, full-length transcripts have been definitively proven to exist within bull spermatozoa, lending credence to the potential function of these mRNAs within the oocyte and embryo. Global comparisons of oocyte and embryo transcripts to spermatozoal transcripts are also needed to further identify targets that may be translated into proteins and impact embryogenesis. 


\section{Acknowledgments:}

This project was supported an Agriculture and Food Research Initiative Competitive Grant no. 2011-67016-20073 from the USDA National Institute of Food and Agriculture to BLS. This research is based in part upon work conducted using the Rhode Island Genomics and Sequencing Center which is supported in part by the National Science Foundation under EPSCoR Grants Nos. 0554548 \& EPS-1004057. 


\section{References:}

Abdelhaleem, M. 2005. RNA helicases: regulators of differentiation. Clinical biochemistry 38:499-503.

Arangasamy, A., V. R. Kasimanickam, J. M. Dejarnette, and R. K. Kasimanickam. 2011. Association of CRISP2, CCT8, PEBP1 mRNA abundance in sperm and sire conception rate in Holstein bulls. Theriogenology 76:570-577.

Avendaño, C., A. Franchi, E. Jones, and S. Oehninger. 2009. Pregnancy-specific \{beta\}-1-glycoprotein 1 and human leukocyte antigen-E mRNA in human sperm: differential expression in fertile and infertile men and evidence of a possible functional role during early development. Human reproduction (Oxford, England) 24:270-7.

Bermejo-Alvarez, P., P. Lonergan, D. Rath, A. Gutiérrez-Adan, and D. Rizos. 2010. Developmental kinetics and gene expression in male and female bovine embryos produced in vitro with sex-sorted spermatozoa. Reproduction, fertility, and development 22:426-36.

Bissonnette, N., J.-P. Lévesque-Sergerie, C. Thibault, and G. Boissonneault. 2009. Spermatozoal transcriptome profiling for bull sperm motility: a potential tool to evaluate semen quality. Reproduction (Cambridge, England) 138:65-80.

Boerke, a, S. J. Dieleman, and B. M. Gadella. 2007. A possible role for sperm RNA in early embryo development. Theriogenology 68 Suppl 1:S147-55.

Card, C., E. J. Anderson, S. Zamberlan, K.-B. E. Krieger, M. Kaproth, and B. L. Sartini. 2013. Cryopreserved Bovine Spermatozoal Transcript Profile as Revealed by High-Throughput Ribonucleic Acid Sequencing. Biology of Reproduction .

Carrell, D. T., and S. S. Hammoud. 2010. The human sperm epigenome and its potential role in embryonic development. Molecular human reproduction 16:37-47.

Chalmel, F., A. D. Rolland, C. Niederhauser-Wiederkehr, S. S. W. Chung, P. Demougin, A. Gattiker, J. Moore, et al. 2007. The conserved transcriptome in human and rodent male gametogenesis. Proceedings of the National Academy of Sciences of the United States of America 104:8346-51.

Gilbert, I., N. Bissonnette, G. Boissonneault, M. Vallée, and C. Robert. 2007. A molecular analysis of the population of mRNA in bovine spermatozoa. Reproduction (Cambridge, England) 133:1073-86.

Gur, Y., and H. Breitbart. 2008. Protein synthesis in sperm: dialog between mitochondria and cytoplasm. Molecular and cellular endocrinology 282:45-55. 
Hamatani, T. 2012. Human spermatozoal RNAs. Fertility and sterility 97:275-81.

Huang, W., and H. Khatib. 2010. Comparison of transcriptomic landscapes of bovine embryos using RNA-Seq. BMC genomics 11:711.

Jenkins, T. G., and D. T. Carrell. 2012. The sperm epigenome and potential implications for the developing embryo. Reproduction (Cambridge, England) 143:727-34.

Johnson, G. D., C. Lalancette, A. K. Linnemann, F. Leduc, G. Boissonneault, and S. a Krawetz. 2011. The sperm nucleus: chromatin, RNA, and the nuclear matrix. Reproduction (Cambridge, England) 141:21-36.

Kempisty, B., P. Antosik, D. Bukowska, M. Jackowska, M. Lianeri, J. M. J. M. Jaśkowski, P. P. Jagodzi'nski, et al. 2008a. Analysis of selected transcript levels in porcine spermatozoa, oocytes, zygotes and two-cell stage embryos. Reproduction, fertility, and development 20:513-8.

Kempisty, B., P. Antosik, D. Bukowska, M. Jackowska, M. Lianeri, J. M. Jaśkowski, and P. P. Jagodzi'nski. 2008b. Analysis of selected transcript levels in porcine spermatozoa, oocytes, zygotes and two-cell stage embryos. Reproduction, Fertility and Development 20:513-518.

Kocabas, A. M., J. Crosby, P. J. Ross, H. H. Otu, Z. Beyhan, H. Can, W.-L. Tam, et al. 2006. The transcriptome of human oocytes. Proceedings of the National Academy of Sciences of the United States of America 103:14027-32.

Lalancette, C., and D. Miller. 2008. Paternal contributions: new functional insights for spermatozoal RNA. Journal of cellular ... 104:1570-1579.

Lalancette, C., C. Thibault, I. Bachand, N. Caron, and N. Bissonnette. 2008.

Transcriptome analysis of bull semen with extreme nonreturn rate: use of suppressionsubtractive hybridization to identify functional markers for fertility. Biology of reproduction 78:618-35.

Liu, W., R. T. K. Pang, P. C. N. Chiu, B. P. C. Wong, K. Lao, and K. Lee. 2012. Sperm-borne microRNA-34c is required for the first cleavage division in mouse. PNAS 109:490-494.

Memili, E., and N. L. First. 2000. Zygotic and embryonic gene expression in cow: a review of timing and mechanisms of early gene expression as compared with other species. Zygote (Cambridge, England) 8:87-96.

Meyer, L. R., A. S. Zweig, A. S. Hinrichs, D. Karolchik, R. M. Kuhn, M. Wong, C. a Sloan, et al. 2013. The UCSC Genome Browser database: extensions and updates 2013. Nucleic acids research 41:D64-9. 
Miki, K., W. D. Willis, P. R. Brown, E. H. Goulding, K. D. Fulcher, and E. M. Eddy. 2002. Targeted Disruption of the Akap4 Gene Causes Defects in Sperm Flagellum and Motility. Developmental Biology 248:331-342.

Miller, D., and G. C. Ostermeier. 2006. Spermatozoal RNA: Why is it there and what does it do? Gynécologie, obstétrique \& fertilité 34:840-6.

Miller, D., G. C. Ostermeier, and S. a Krawetz. 2005. The controversy, potential and roles of spermatozoal RNA. Trends in molecular medicine 11:156-63.

Misirlioglu, M., G. P. Page, H. Sagirkaya, a Kaya, J. J. Parrish, N. L. First, and E. Memili. 2006. Dynamics of global transcriptome in bovine matured oocytes and preimplantation embryos. Proceedings of the National Academy of Sciences of the United States of America 103:18905-10.

Ostermeier, G. C., D. Miller, J. D. Huntriss, M. P. Diamond, and S. A. Krawetz. 2004. Delivering spermatozoan RNA to the oocyte. Nature 429:2603.

Sekiguchi, T., H. Iida, J. Fukumura, and T. Nishimoto. 2004. Human DDX3Y, the Yencoded isoform of RNA helicase DDX3, rescues a hamster temperature-sensitive ET24 mutant cell line with a DDX3X mutation. Experimental cell research 300:21322.

Suri, A. 2004. Sperm specific proteins-potential candidate molecules for fertility control. Reproductive biology and endocrinology $\square: \operatorname{RB} \& E$ 2:10.

Swann, K., C. M. Saunders, N. T. Rogers, and F. a Lai. 2006. PLCzeta(zeta): a sperm protein that triggers $\mathrm{Ca} 2+$ oscillations and egg activation in mammals. Seminars in cell \& developmental biology 17:264-73.

Thelie, A., P. Papillier, C. Perreau, S. Uzbekova, C. Hennequet-Antier, and R. Dalbies-Tran. 2009. Regulation of bovine oocyte-specific transcripts during in vitro oocyte maturation and after maternal-embryonic transition analyzed using a transcriptomic approach. Molecular reproduction and development 76:773-82.

Vigneault, C., C. Gravel, M. Vallée, S. McGraw, and M.-A. Sirard. 2009. Unveiling the bovine embryo transcriptome during the maternal-to-embryonic transition. Reproduction (Cambridge, England) 137:245-57.

Vong, Q. P., Y. Li, Y.-F. C. Lau, M. Dym, O. M. Rennert, and W.-Y. Chan. 2006. Structural characterization and expression studies of Dby and its homologs in the mouse. Journal of andrology 27:653-61.

Yao, C. J., W. J. Xu, X. L. Gong, Y. Zhou, Z. Q. Yan, Z. J. Zhu, Z. X. Wang, et al. 2010a. The role of Dby mRNA in early development of male mouse zygotes. Asian Journal of Andrology 12:567-577. 
Yao, C., Z. Wang, Y. Zhou, W. Xu, Q. Li, D. Ma, L. Wang, et al. 2010b. A study of Y chromosome gene mRNA in human ejaculated spermatozoa. Molecular reproduction and development 77:158-66. 


\section{Figures}

Figure 1: Alignment of spermatozoa transcript RNA-Seq reads (bottom line) with bovine genome in UCSC Mappings (Meyer et al. 2013) using bovine spermatozoa RNA-Seq data from (Card et al. 2013) for bovine spermatozoa transcripts assayed in this study. Untranslated Regions (UTRs) are included in all transcripts shown here as thinner black lines at both ends of each transcript. RNA-Seq mappings don't show separate UTRs and have a continuous thick black line. Summary of read mappings indicating full-length (all exons mapped) or degraded transcripts (exons missing) is indicated on the right. Extra exons sequenced in RNA-Seq but not visualized in the bovine genome are also indicated. 
(A)

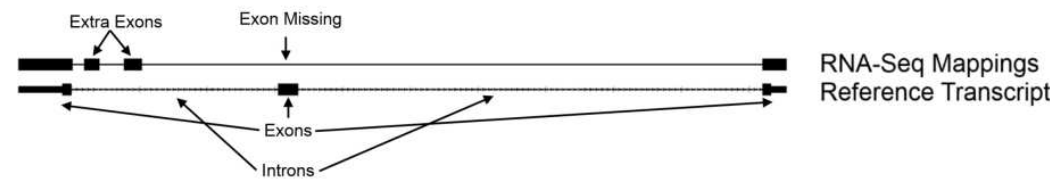

(B)

Transcript Genbank ID

AF136609

COX7A2 DQ347636

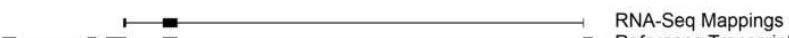

CCT8

CRISP

BC109478

$!$

EEF1A1 AB099079

EEF1

AB098752

GSTM3 BC112491

=

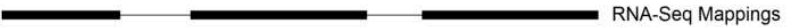

-

RNA-Seq Mappings

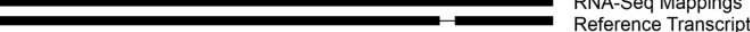

(1) BC108207
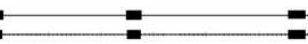

$=$

RNA-Seq Mappings

PRM

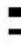

PSMA

BC102216

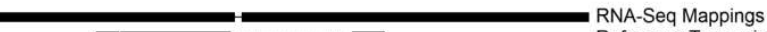

$\begin{array}{lll}\text { HMGB4 BC109790 } & \text { RNA-Seq Mappings } \\ \text { Reference Transcript }\end{array}$

GTSF1 BC102713:

CKS2 BC105331

H2AFZ BC109743 RNA-Seq Mappings

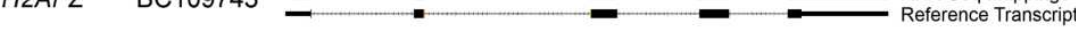

PSMA6 BC110260 :

SEC61G BC102186: ,

CMYC RNA-Seq Mappings

CMYC BC109848:

SPA17 BC103421:

PLCZ1 AY646356 , , , , , , , , , RNA-Seq Mappings

AKAP4 AF100170

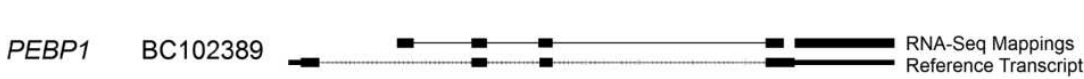

PEBP1 BC102389 $=$ Reference Transcript

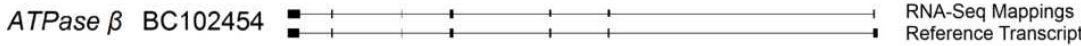

CLGN BC103401 $\longmapsto,,,,,,, 1,1$, RNA-Seq Mappings

CHMP5 BC103182

UBE2N BT030506 :

Reference Transcrip

DDX3Y GQ259590

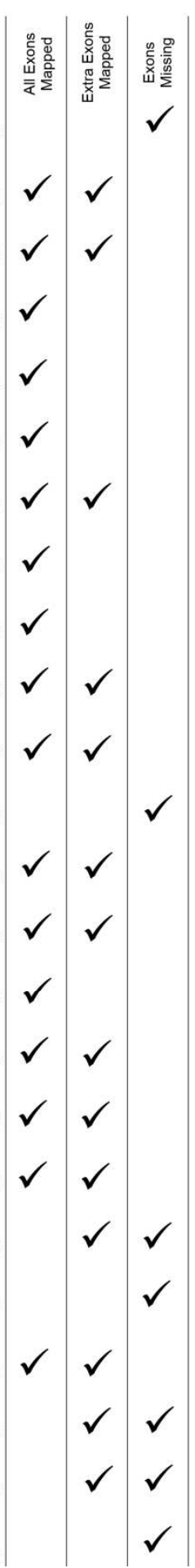


Figure 2: Full-length bovine spermatozoal transcripts A) Transcripts sequenced from a single amplicon, spanning from 5' exon to the 3' exon. B) Transcripts sequenced from two overlapping amplicons, bands shown that cover 5' and 3' ends C) Transcript sequenced from three overlapping amplicons, from 5' to midsection to 3' ends. D) Full-length transcript found with an alternative 3'UTR. Negative control = no template.

(A)

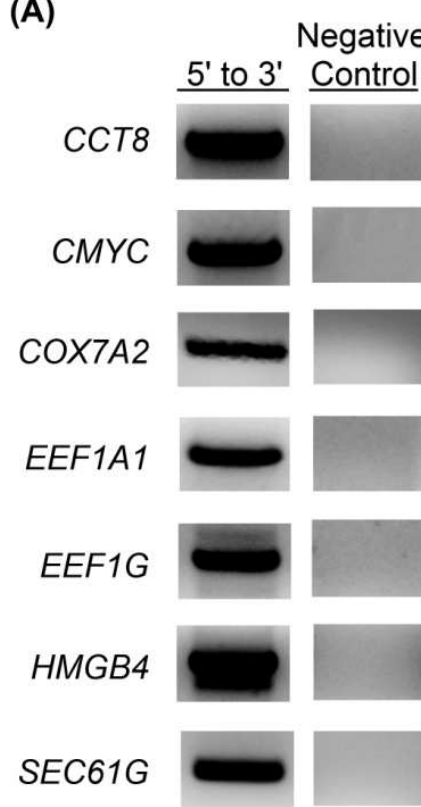

(B)

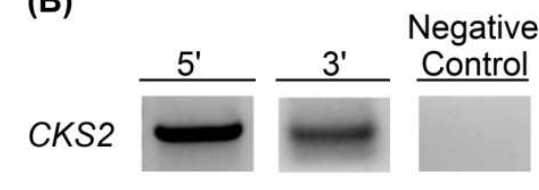

\section{GSTM3}

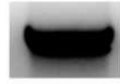

GTSF1
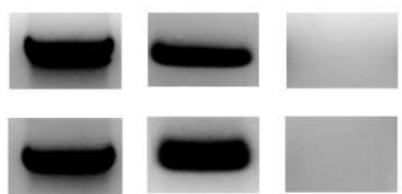

GTS1

$H 2 A F Z$
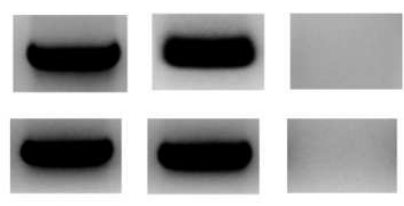

PRM1

PSMA1
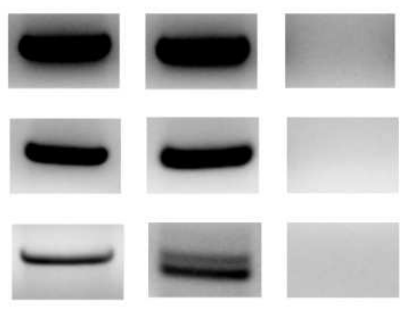

(C)

C)

$5^{\prime}$ Middle

CRISP2

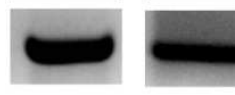

PLCZ1
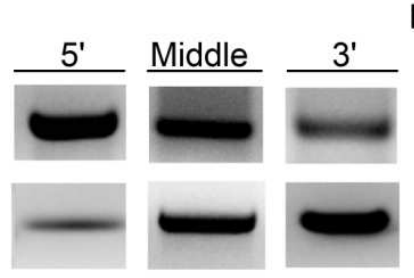

Negative

Control

(D)

Negative

PSMA6

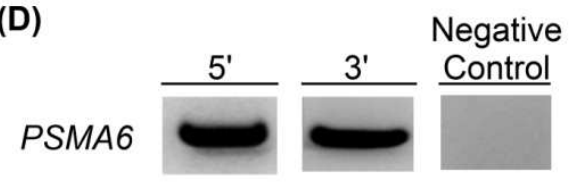


Figure 3: Degraded transcripts present in the bovine spermatozoa transcript profile. A) Transcripts with degradation, amplicons sorted by 5' to 3' end location. B) Transcripts degraded on the 5' end, as well as having alternative 3'UTR. ATPase $\beta$ and CHMP5 have only one band, but the band size and location of the poly(A) tail were different from the reference accession. Negative control $=$ no template.

(A)
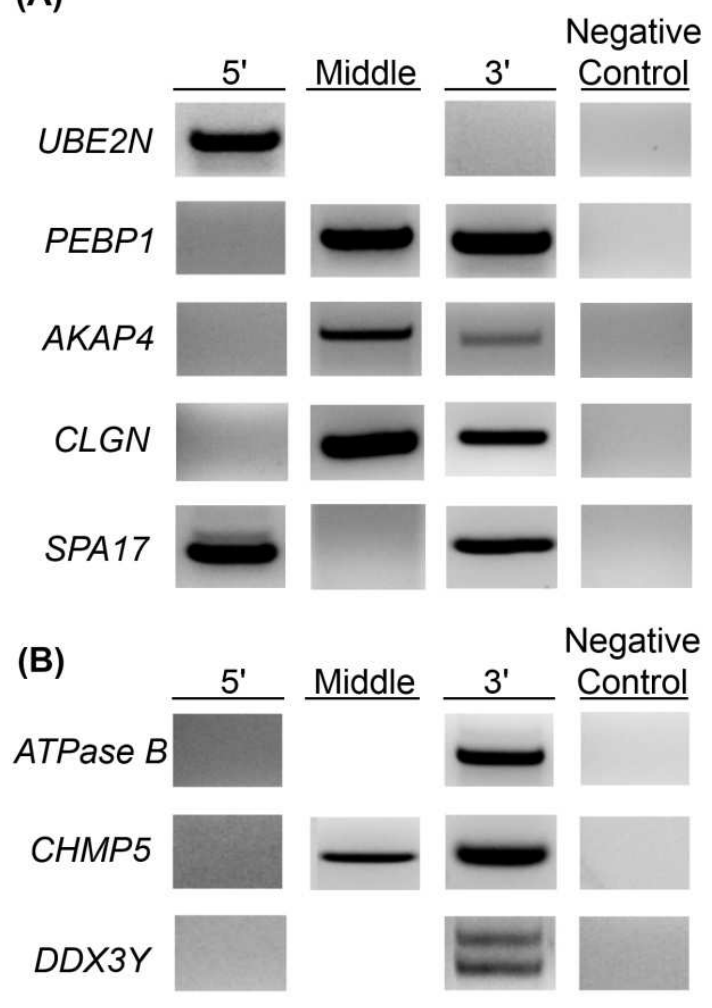
Figure 4: Oocyte and 2-Cell Embryo PCRs. All genes are arranged in order from left to right that the PCRs were performed. $\mathrm{CO}=\mathrm{cDNA}$ oocyte, $\mathrm{CE}=\mathrm{cDNA}$ 2-cell embryo, NT= No Template Control, NR= No RT Template Control, RO=RACE oocyte, $\mathrm{RE}=\mathrm{RACE}$ 2-cell embryo, $\mathrm{Sp}=$ Spermatozoa cDNA from 9-bull pool.

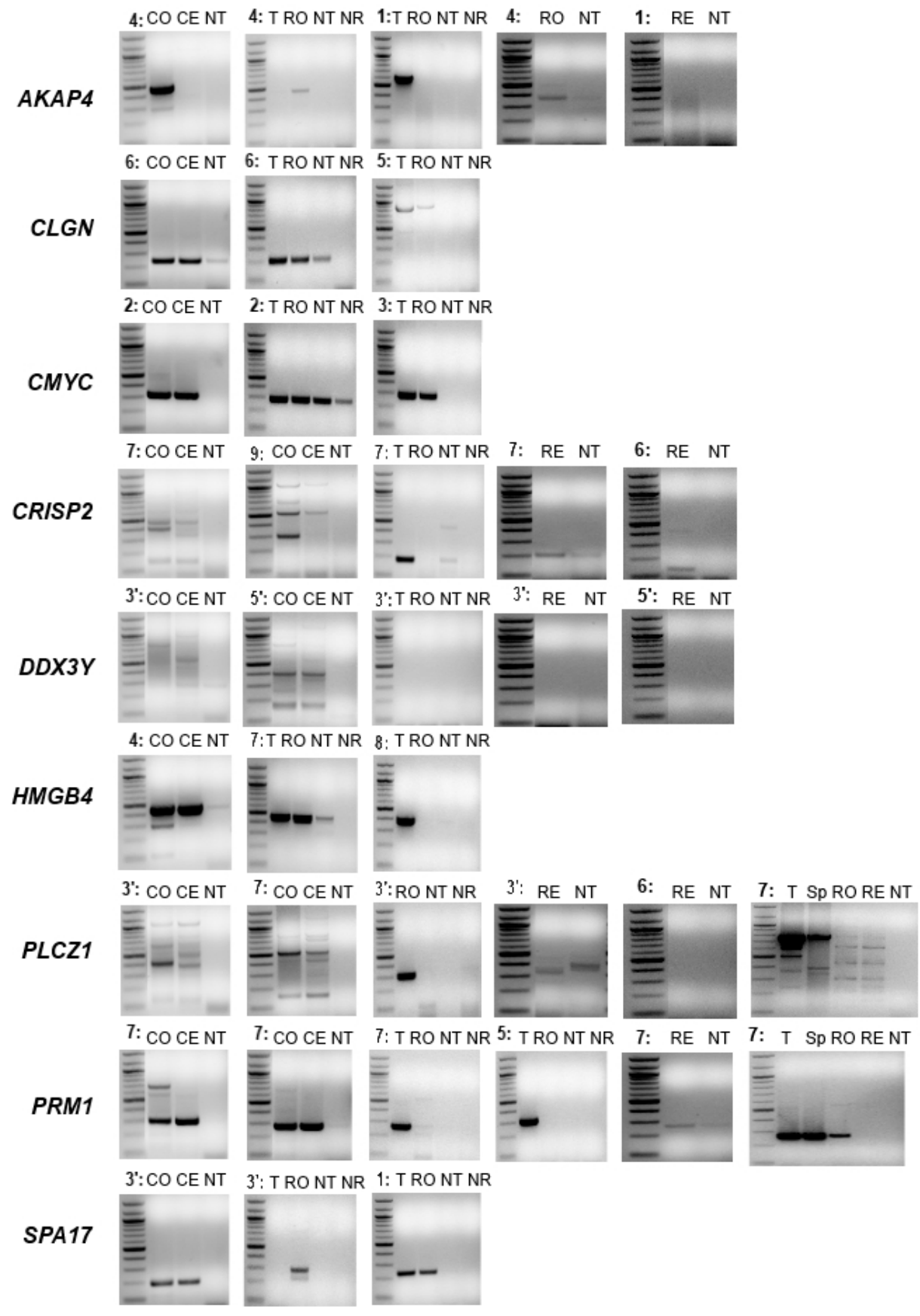




\section{$\underline{\text { Tables }}$}

Table 1: Transcript identification methods. Lit=Literature Searches, $Y$ Csome $=Y$ chromosome located, $\mathrm{GO}=$ found in gene ontology translation category

\begin{tabular}{|c|c|c|c|}
\hline Gene & FPKM & $\begin{array}{l}\text { Discovery } \\
\text { Method }\end{array}$ & Reference \\
\hline AKAP4 & 126.623 & Lit & $\begin{array}{l}\text { Ostermeier et al., 2005; Iguchi et al., 2006; Miller et al., 2006; } \\
\text { Boerke et al., 2007; Gilbert et al., 2007; Peddinti et al., } 2008\end{array}$ \\
\hline ATPase $\beta$ & 90.1644 & High FPKM & \\
\hline CСT8 & 17.9915 & Lit & Arangasamy et al., 2011 \\
\hline CHMP5 & 2778.08 & High FPKM & \\
\hline CKS2 & 351.893 & Lit & Donovan et al., 2003; Smirnova et al., 2006 \\
\hline CLGN & 220.011 & Lit & Iguchi et al., 2006; Hecht et al., 2010; Evans, 2012 \\
\hline CMYC & 39.731 & Lit & $\begin{array}{l}\text { Miller et al., 2006; Gilbert et al., 2007; Gur et al., 2008; Mayr et } \\
\text { al., 2009; Johnson et al., 2011; Hamatani, 2012; Liu et al., } 2012\end{array}$ \\
\hline COX7A2 & 719.358 & Lit & $\begin{array}{l}\text { Misirlioglu et al., 2006; Bermejo-Alvarez et al., 2010; Alshagga } \\
\text { et al., } 2011\end{array}$ \\
\hline CRISP2 & 0.317044 & Lit & Arangasamy et al., 2011 \\
\hline DDX3Y & 10.9846 & Lit, Y Csome & $\begin{array}{l}\text { Sekiguchi et al., 2004; Vong et al., 2006; Yao et al., 2010; Paria } \\
\text { et al., } 2011\end{array}$ \\
\hline EEF1A1 & 431.873 & GO & \\
\hline EEF1G & 116.059 & GO & \\
\hline GSTM3 & 2373.84 & Lit & $\begin{array}{l}\text { Misirlioglu et al., 2006; Bermejo-Alvarez et al., 2010; Alshagga } \\
\text { et al., } 2011\end{array}$ \\
\hline GTSF1 & 896.368 & High FPKM & \\
\hline $\mathrm{H} 2 \mathrm{AFZ}$ & 166.742 & Lit & $\begin{array}{l}\text { Misirlioglu et al., 2006; Gilbert et al., 2007; Vigneault et al., } \\
\text { 2009; Bermejo-Alvarez et al., } 2010\end{array}$ \\
\hline HMGB4 & 6021.96 & High FPKM & \\
\hline PEBP1 & 29.3446 & Lit & Arangasamy et al., 2011 \\
\hline PLCZ1 & 41.3639 & Lit & $\begin{array}{l}\text { Miller et al., 2006; Swann et al., 2006; Boerke et al., 2007; } \\
\text { Avendaño et al., 2009; Johnson et al., 2011; Fischer et al., 2012; } \\
\text { Hamatani, 2012 }\end{array}$ \\
\hline PRM1 & 20667.2 & Lit & $\begin{array}{l}\text { Lassalle et al., 1999; Ostermeier et al., 2002; Miller et al., 2006; } \\
\text { Gilbert et al., 2007; Lalancette et al., 2008; Avendaño et al., } \\
\text { 2009; Bissonnette et al., 2009; Carrell et al., 2010; Feugang et } \\
\text { al., 2010; Hecht et al., 2010; Johnson et al., 2011; Ganguly et al., } \\
\text { 2012; Jenkins et al., 2012 }\end{array}$ \\
\hline PSMA1 & 84.5454 & High FPKM & \\
\hline PSMA6 & 913.21 & High FPKM & \\
\hline SEC61G & 309.446 & High FPKM & \\
\hline SPA17 & 927.374 & High FPKM & \\
\hline UBE2N & 245.596 & High FPKM & \\
\hline
\end{tabular}


Table 2: Primers Used for PCR Amplification

\begin{tabular}{|c|c|c|c|c|c|c|}
\hline Gene & $\begin{array}{l}\text { Genbank } \\
\text { ID }\end{array}$ & Set & Forward $\left(5^{\prime} \rightarrow 3^{\prime}\right)$ & Reverse $\left(5^{\prime} \rightarrow 3^{\prime}\right)$ & $\begin{array}{c}\text { BP } \\
\text { Covered }\end{array}$ & $\begin{array}{l}\text { Tota } \\
\text { I BP }\end{array}$ \\
\hline AKAP4 & AF100170 & $\begin{array}{l}1 \\
2 \\
3\end{array}$ & $\begin{array}{l}\text { AGGGGTCAGTGTGCCTTTTC } \\
\text { AACATGCACTGAGCCCTTCA } \\
\text { TTTTACCAGACCAGTGGCCC } \\
\text { CTACCAAGACTCTCACGGGC } \\
\text { ACTTGGCACTGCCCACTTC } \\
\text { GCTTCTGAAATGGCCCATGAT } \\
\text { GAAAAGTGCGGAGGTAGCCA }\end{array}$ & $\begin{array}{l}\text { TCGACCACCATCCCTACACT } \\
\text { TGGGCCATTTCAGAAGCGAT } \\
\text { GACACCCTGTATTTGCACAGTC } \\
\text { ACACCCTGTATTTGCACAGTC } \\
\text { TCCAGACGTAGGCTCTGAGG } \\
\text { TCTTCACAGTTGAAGGGGCTC } \\
\text { GACACCCTGTATTTGCACAGTC }\end{array}$ & $\begin{array}{cc}385 & -998 \\
481 & -931 \\
231 & 284 \\
0 & -0 \\
236 & 283 \\
3 & -9 \\
41 & -618 \\
& 202 \\
915 & -4 \\
185 & 284 \\
7 & -0 \\
\end{array}$ & 2900 \\
\hline ATPase $\beta$ & BC102454 & $\begin{array}{l}1 \\
2\end{array}$ & $\begin{array}{l}\text { TGAGCGCACTCTGCTTGAG } \\
\text { GCACACACACCATGACGAAG } \\
\text { AATGTGGGCCATGCTTCAGA } \\
\text { AGATAATAGTGGTCCATGTCCTTC } \\
\text { G }\end{array}$ & $\begin{array}{l}\text { CAGGAACTCTCCGGTTGTCC } \\
\text { ATCCAACGCTGACACTGGTT } \\
\text { GTTCAAAAGGCAGCAGAGGC } \\
\text { CACTGAATTTCTTGCAGCTATGA }\end{array}$ & $\begin{array}{rl}1 & -253 \\
156 & -442 \\
& 121 \\
337 & -0 \\
115 & 117 \\
1 & -5 \\
\end{array}$ & 1525 \\
\hline CCT8 & AF136609 & 1 & CGAGATGGTGCCATTTCTACC & TCTTTCTTCCCACTTGGAGGC & $11-531$ & 555 \\
\hline CHMP5 & BC103182 & $\begin{array}{l}1 \\
2 \\
3\end{array}$ & $\begin{array}{l}\text { GAGTGTTTAGGTTTTCCTAGCGG } \\
\text { TGGCACGGTGGACAGCAGAG } \\
\text { GGAGTCCTGGTGGATGAATTTGG }\end{array}$ & $\begin{array}{l}\text { GAAAGCCTCCTCCAAGCAA } \\
\text { GAAAGCCTCCTCCAAGCAA } \\
\text { AGCCTCCTCCAAGCAACGAGT }\end{array}$ & $\begin{array}{r}1-869 \\
95-869 \\
645-866 \\
\end{array}$ & 1355 \\
\hline CKS2 & BC105331 & $\begin{array}{l}1 \\
2\end{array}$ & $\begin{array}{l}\text { GAGTCGAGTCGTTGCCTTCA } \\
\text { CTTCACCTGACCCGGACGTT }\end{array}$ & $\begin{array}{l}\text { GGACACCAAGTCTCCTCCAC } \\
\text { AAAACACCTTACAGTAACCTACTT } \\
\text { G }\end{array}$ & $\begin{array}{r}1-248 \\
16-528\end{array}$ & 737 \\
\hline CLGN & BC103401 & $\begin{array}{l}2 \\
3 \\
\end{array}$ & $\begin{array}{l}\text { TGGATTGAGCTGGGGGAGA } \\
\text { GGGCCCGCAAGACAGATAAT } \\
\text { ATGGATGGAGAATGGGAGGC }\end{array}$ & $\begin{array}{l}\text { ATTCACCACACCCAATCCGA } \\
\text { TCAAGCCAGCCATCAGGTTT } \\
\text { GAAACTTTATTGCAATCAGCTCTG } \\
\text { T }\end{array}$ & $\begin{array}{rl} & 118 \\
26 & -1 \\
& 105 \\
98 & -6 \\
111 & 238 \\
8 & -5 \\
\end{array}$ & 2450 \\
\hline CMYC & BC109848 & $\begin{array}{l}1 \\
2 \\
3 \\
4\end{array}$ & $\begin{array}{l}\text { GGCCGCTGTCACTATGGC } \\
\text { TGTCACTATGGCCCATTACAAA } \\
\text { ACTTAGGAGCTGCTACCCCA } \\
\text { CCACCTCAGGAGGAGAAACG } \\
\end{array}$ & $\begin{array}{l}\text { TCCTCCTGAGGTGGTTCATACT } \\
\text { TGGTGAGGTGGTTCATACTGAG } \\
\text { ACAGTTAACGTGTGATAGGTGA } \\
\text { ACAGTTAACGTGTGATAGGTGAAT }\end{array}$ & $\begin{array}{r}1-309 \\
7-306 \\
165-463 \\
296-463 \\
\end{array}$ & 528 \\
\hline COX7A2 & DQ347636 & 1 & AACTGGCTGTGGCTTCGTTT & TGCTTTATTGGTGGCAGCTAA & $1-204$ & 206 \\
\hline CRISP2 & BC109478 & $\begin{array}{l}1 \\
2 \\
3\end{array}$ & $\begin{array}{l}\text { CGGCCGCTCTGCAACAGAAG } \\
\text { AGTCTCTCCACCTGCCAGTA } \\
\text { CACCTTGCGGCAGTTGCCCT } \\
\end{array}$ & $\begin{array}{l}\text { GTGCACTTGTTTGCCCACTT } \\
\text { TGCCTTCACACAGACAAGTCGCC } \\
\text { TGCCTTCACACAGACAAGTCGCC }\end{array}$ & $\begin{array}{r}20-437 \\
207-959 \\
761-922 \\
\end{array}$ & 1382 \\
\hline DDX3Y & GQ259590 & $\begin{array}{l}1 \\
2\end{array}$ & $\begin{array}{l}\text { TTGTTTCCGGTAGACCAACCTGTG } \\
\text { GGCCGTTCTAGGAGATTCAGTGG }\end{array}$ & \begin{tabular}{|l|} 
AGCGCCCTTTGCTAGCTGTACT \\
CAACTGAATCTGCTTTCCAGCCAA \\
G
\end{tabular} & $\begin{array}{cc}15 & -234 \\
187 & 212 \\
5 & -0\end{array}$ & 2790 \\
\hline EEF1A1 & AB099079 & 1 & TCGTGTGGAGACTGGTGTTCT & $\begin{array}{l}\text { TTAAAGACTGGGGTGGCAGTATTG } \\
\text { G }\end{array}$ & $4-634$ & 636 \\
\hline EEF1G & AB098752 & 1 & TCTTGCCCTGATTGAAGGCT & ATGGCTGGTCCCTGTGG & $89-443$ & 443 \\
\hline GSTM3 & BC112491 & $\begin{array}{l}1 \\
2 \\
\end{array}$ & $\begin{array}{l}\text { GCGCTAAGGCACACAGGCGA } \\
\text { CCGCATGCTCCTGGAGTTCACG }\end{array}$ & \begin{tabular}{|l|} 
GGGCCATCTTGTTGTTGACAGGCA \\
$\mathrm{T}$ \\
GTACAAGTCTGCCTCCTGCTC \\
\end{tabular} & $\begin{array}{r}5-683 \\
94-728 \\
\end{array}$ & 823 \\
\hline GTSF1 & BC102713 & $\begin{array}{l}1 \\
2 \\
\end{array}$ & $\begin{array}{l}\text { GAGCACTTTGGATTTGGCTCC } \\
\text { AACTGGCAACTTGTCCCTTCA }\end{array}$ & $\begin{array}{l}\text { CACGTGCTCTCAGCCATAGT } \\
\text { GCAACTCACAGACAGTTTATCTT }\end{array}$ & $\begin{array}{r}1-326 \\
173-650 \\
\end{array}$ & 666 \\
\hline H2AFZ & BC109743 & $\begin{array}{l}1 \\
2\end{array}$ & $\begin{array}{l}\text { TGAGCGCAGTTTGAATCGC } \\
\text { GTGGTGTCATTCCACACATCC }\end{array}$ & $\begin{array}{l}\text { CCACCACCAGCAATTGTAGC } \\
\text { ATGACCTTTATTGAGCTTATCCAC } \\
\text { C }\end{array}$ & $\begin{array}{r}1-436 \\
433-863 \\
\end{array}$ & 884 \\
\hline HMGB4 & BC109790 & 1 & ACAGAAAATTTCACCGCCAGC & GACTCAGCTTGCTCGAACTCT & $8-679$ & 764 \\
\hline PEBP1 & BC102389 & 1 & TTTAACCTGGGTGGGTGTCAGC & CTCGTAAACCAGCCAGACATAGC & $218-476$ & 1476 \\
\hline
\end{tabular}




\begin{tabular}{|c|c|c|c|c|c|c|}
\hline & & 3 & $\begin{array}{l}\text { CCGATTATGTGGGCTCTGGG } \\
\text { AAGAGATTGACTGTCTCCGCC }\end{array}$ & $\begin{array}{l}\text { ACCAACTCCAGAACAGTTTTCTTT } \\
\mathrm{T} \\
\text { ACAATATTCACCAACTCCAGAACA }\end{array}$ & $\begin{array}{rl} & 134 \\
409 & -1 \\
100 & 135 \\
9 & -0\end{array}$ & \\
\hline PLCZ1 & AY646356 & 1 & $\begin{array}{l}\text { GCGTTTGGACCCAAAGGAAA } \\
\text { TTTGGGGATGCCTTGCTGTC } \\
\text { GGTCGGAATCCCACTCTTCA }\end{array}$ & $\begin{array}{l}\text { AGCAAGGCATCCCCAAATGT } \\
\text { AAGGCCACCATTTGACAACC } \\
\text { AAAAGGGAAGCGGGCTCAA }\end{array}$ & $\begin{array}{rl} & 108 \\
6 & -9 \\
107 & 165 \\
3 & -0 \\
134 & 209 \\
8 & -6\end{array}$ & 2096 \\
\hline PRM1 & BC108207 & $\begin{array}{l}1 \\
2 \\
\end{array}$ & $\begin{array}{l}\text { GACAGCCCACAAATTCCACC } \\
\text { GCCAGATACCGATGCTCCTCA }\end{array}$ & $\begin{array}{l}\text { GCAAGAGGGTCTTGAAGGCT } \\
\text { GTTAGCAGGCTCCTGTTCATGTC }\end{array}$ & $\begin{array}{r}1-313 \\
98-364 \\
\end{array}$ & 517 \\
\hline PSMA1 & BC102216 & 1 & $\begin{array}{l}\text { TTCCACCCGCAGGTTTGAAG } \\
\text { TTACGGGAAACCCTTCCTGC } \\
\end{array}$ & $\begin{array}{l}\text { GCTGATTGAGATCGGGCTCC } \\
\text { ACAGTTGTCTTTAAAACCACAAAG } \\
\text { A }\end{array}$ & $\begin{array}{r}3-554 \\
113 \\
634-2 \\
\end{array}$ & 1172 \\
\hline PSMA6 & BC110260 & $\begin{array}{l}1 \\
2\end{array}$ & $\begin{array}{l}\text { GAGGGACGGCTCTACCAAGT } \\
\text { CGAAATTCCCGTGGACATGC } \\
\text { TGGGTTTAAAGCAACTGCAGCAGG } \\
\text { A }\end{array}$ & $\begin{array}{l}\text { AGAGGCCGCATTTCAGCATT } \\
\text { TGGCGTCACGGATTTGGTAA } \\
\text { ATCGAGGGGCCCCCAAAATGT }\end{array}$ & $\begin{array}{l}118-464 \\
384-838 \\
546-889\end{array}$ & 984 \\
\hline SEC61G & BC102186 & 1 & GGCTCCTGTGCTACGTGTC & TTTCTGCTCCATCAGCTTCTCA & $5-339$ & 523 \\
\hline SPA17 & BC103421 & $\begin{array}{l}1 \\
2 \\
3\end{array}$ & $\begin{array}{l}\text { CCGGAACCATCGACTCCAGCTC } \\
\text { GGGGCTAAGGTTGATGACCGC } \\
\text { TCAAGGAGCAAGAATCACCTG }\end{array}$ & $\begin{array}{l}\text { TCTTGCTCCTTGAATGCATGGTTG } \\
\mathrm{T} \\
\text { GGCTAAGTGTCCCCGGAAGGC } \\
\text { GTGGGGGTAAAGCCAGTCTC }\end{array}$ & $\begin{array}{r}23-319 \\
267-464 \\
307-551\end{array}$ & 780 \\
\hline UBE2N & BT030506 & 2 & $\begin{array}{l}\text { TGACAAGATGGCCGGGCTGC } \\
\text { ATCATCGGTGTCTTGCCACA } \\
\end{array}$ & $\begin{array}{l}\text { GTGAGGGCTGTGATGTCTGT } \\
\text { GAACAGCTTTGTGGTGGGGA }\end{array}$ & $\begin{array}{rl} & 106 \\
27 & -8 \\
150 & 193 \\
3 & -5 \\
\end{array}$ & 2218 \\
\hline
\end{tabular}


Table 3: Sequencing of bovine spermatozoa transcripts where base pairs matched the predicted transcript using primers in Table $1 . \mathrm{Y}=\mathrm{Yes}, \mathrm{N}=\mathrm{No}, \mathrm{n} / \mathrm{a}=\operatorname{no}$ poly $(\mathrm{A})$ present in genbank accession, $*=$ Poly A tail is present but not where the original accession number indicates it. A) full-length transcripts B) degraded transcripts

A)

\begin{tabular}{|l|l|l|l|ll|c|}
\hline Gene & $\begin{array}{l}\text { Genbank } \\
\text { ID }\end{array}$ & $\begin{array}{c}\text { Total } \\
\text { BP }\end{array}$ & $\begin{array}{l}\% \\
\text { Sequenced }\end{array}$ & BP sequenced & $\begin{array}{c}\text { Poly A } \\
\text { Tail }\end{array}$ \\
\hline CCT8 & AF136609 & 554 & 100 & 1 & -536 & Y \\
\hline COX7A2 & BC102664 & 205 & 100 & 1 & -205 & N \\
\hline CRISP2 & BC109478 & 1382 & 100 & 1 & -1382 & Y \\
\hline EEF1A1 & AB099079 & 636 & 100 & 1 & -636 & Y \\
\hline EEF1G & AB098752 & 443 & 100 & 1 & -443 & Y \\
\hline GSTM3 & BC112491 & 823 & 100 & 1 & -823 & Y \\
\hline PLCZ1 & AY646356 & 2096 & 97 & 68 & -2096 & Y \\
\hline PRM1 & BC108207 & 517 & 100 & 1 & -517 & Y \\
\hline PSMA1 & BC102216 & 1172 & 100 & 1 & -1172 & Y \\
\hline HMGB4 & BC109790 & 764 & 94 & 45 & -764 & Y \\
\hline GTSF1 & BC102713 & 666 & 94 & 43 & -666 & Y \\
\hline CKS2 & BC105331 & 737 & 93 & 49 & -737 & Y \\
\hline H2AFZ & BC109743 & 884 & 93 & 1 & -437 & Y \\
& & & & 497 & -884 & \\
\hline PSMA6 & BC110260 & 984 & 90 & 1 & -890 & Y* \\
\hline SEC61G & BC102186 & 523 & 89 & 57 & -523 & \\
\hline CMYC & BC109848 & 528 & 89 & 1 & -461 & $\mathrm{~N}$ \\
\hline
\end{tabular}

B)

\begin{tabular}{|c|c|c|c|c|c|c|}
\hline Gene & $\begin{array}{l}\text { Genbank } \\
\text { ID }\end{array}$ & $\begin{array}{c}\text { Total } \\
\text { BP }\end{array}$ & $\begin{array}{l}\% \\
\text { Sequenced }\end{array}$ & \multicolumn{2}{|c|}{ BP sequenced } & $\begin{array}{c}\text { Poly A } \\
\text { Tail }\end{array}$ \\
\hline SPA17 & BC103421 & 780 & 60 & $\begin{array}{l}1 \\
370\end{array}$ & $\begin{array}{l}-320 \\
-\quad 514\end{array}$ & $\mathrm{~N}$ \\
\hline AKAP4 & AF100170 & 2900 & 50 & $\begin{array}{l}440 \\
2056\end{array}$ & $\begin{array}{ll}- & 1038 \\
- & 2900\end{array}$ & $Y$ \\
\hline PEBP1 & BC102389 & 1476 & 50 & $\begin{array}{l}370 \\
1060\end{array}$ & $\begin{array}{ll}- & 684 \\
- & 1476\end{array}$ & $\mathrm{~N}$ \\
\hline $\begin{array}{l}\text { ATPase } \\
\beta\end{array}$ & BC102454 & 1525 & 31 & 1055 & - 1525 & $Y^{*}$ \\
\hline CLGN & BC103401 & 2450 & 31 & $\begin{array}{l}117 \\
1017 \\
1656 \\
2105\end{array}$ & $\begin{array}{ll}- & 327 \\
- & 1181 \\
- & 1684 \\
- & 2450\end{array}$ & $\mathrm{Y}$ \\
\hline CHMP5 & BC103182 & 1355 & 22 & $\begin{array}{l}66 \\
647\end{array}$ & $\begin{array}{l}-269 \\
-\quad 740\end{array}$ & $\mathrm{Y}^{*}$ \\
\hline UBE2N & BT030506 & 2218 & 21 & $\begin{array}{l}160 \\
878\end{array}$ & $\begin{array}{ll}- & 442 \\
- & 1067\end{array}$ & $\mathrm{~N}$ \\
\hline DDX3Y & GQ259590 & 2790 & 12 & $\begin{array}{l}9 \\
1948\end{array}$ & $\begin{array}{ll}- & 87 \\
- & 2203\end{array}$ & $\mathrm{Y}^{*}$ \\
\hline
\end{tabular}


Table 4: Transcript presence in testis, sperm, oocyte and embryos from published microarray studies. $\mathrm{Y}=$ transcript present, $\mathrm{N}=$ transcript absent, $\mathrm{M}=$ results inconclusive. Oocyte \& Embryo microarray data are from Kocabas et al. 2006. Testis and spermatozoa microarray data are from Chalmel et al., 2007.

\begin{tabular}{|l|l|c|c|c|c|}
\hline Gene & $\begin{array}{l}\text { Genbank } \\
\text { ID }\end{array}$ & Testis & Sperm & Oocyte & Embryo \\
\hline AKAP4 & AF100170 & Y & Y & N & N \\
\hline $\begin{array}{l}\text { ATPase } \\
\beta\end{array}$ & BC102454 & Y & Y & Y & N \\
\hline CCT8 & AF136609 & Y & Y & Y & Y \\
\hline CHMP5 & BC103182 & Y & Y & Y & N \\
\hline CKS2 & BC105331 & Y & M & Y & Y \\
\hline CLGN & BC103401 & Y & M & N & N \\
\hline CMYC & BC109848 & Y & N & N & Y \\
\hline CRISP2 & BC109478 & Y & Y & N & Y \\
\hline DDX3Y & GQ259590 & Y & Y & N & Y \\
\hline EEF1A1 & AB099079 & Y & Y & Y & N \\
\hline EEF1G & AB098752 & Y & Y & Y & Y \\
\hline GSTM3 & BC112491 & Y & Y & Y & N \\
\hline GTSF1 & BC102713 & Y & Y & Y & N \\
\hline H2AFZ & BC109743 & Y & Y & M & Y \\
\hline HMGB4 & BC109790 & Y & Y & N & Y \\
\hline PEBP1 & BC102389 & Y & Y & Y & Y \\
\hline PLCZ1 & AY646356 & Y & Y & N & N \\
\hline PRM1 & BC108207 & Y & Y & N & N \\
\hline PSMA1 & BC102216 & Y & Y & Y & Y \\
\hline PSMA6 & BC110260 & Y & Y & M & Y \\
\hline SEC61G & BC102186 & Y & M & Y & Y \\
\hline SPA17 & BC103421 & Y & Y & N & N \\
\hline UBE2N & BT030506 & Y & Y & Y & M \\
\hline
\end{tabular}




\section{APPENDICES}

\section{APPENDIX I: PROTOCOLS}
A) Testis RNA Isolations
B) Spermatozoa RNA Isolations
C) Oocyte \& Embryo RNA Isolations
D) Reverse Transcription
E) Standard Polymerase Chain Reaction
F) cDNA Amplification
G) Rapid Amplification of cDNA Ends Polymerase Chain Reaction
H) Primer Dilution from IDT
I) Gel Extraction Protocol
J) Sequencing
K) RNA-Sequencing Protocols 


\section{A) Testis RNA Isolation Protocol}

Tips \& Techniques:

- Turn on microfuge and let cool to $4^{\circ} \mathrm{C}$ (20 minutes)

- Set up a ribonuclease free environment

○ Preparation: RNase/DNase free microfuge tubes, tips etc.

- $\quad$ KEEP SAMPLE ON ICE - except where noted

\section{$\underline{\text { Protocol }}$}

1. Add 200 ul of TRI REAGENT to $100 \mathrm{mg}$ tissue and homogenize with RNase-free blue pestle on ice. Add additional 800 ul of TRI REAGENT and mix.

2. Let sit at room temperature for $5 \mathrm{~min}$ (Can store in $-80^{\circ} \mathrm{C}$ at this point)

3. Add $0.2 \mathrm{ml}$ of chloroform per $1 \mathrm{ml}$ of TRI REAGENT

4. Shake vigorously for $15 \mathrm{sec}$ and let stand for $2-15 \mathrm{~min}$

5. Centrifuge at $12,000 \mathrm{xg}$ for $15 \mathrm{~min}$ at $4{ }^{\circ} \mathrm{C}$

6. Remove clear aqueous phase (top layer) and transfer to a new tube

7. Add $0.5 \mathrm{ml}$ isopropanol/ml TRI REAGENT and let sit for 5-10 $\mathrm{min}$ at RT

8. Centrifuge at $12,000 \mathrm{~g}$ for $10 \mathrm{~min}$ at $4^{\circ} \mathrm{C}$

9. Remove supernatant and wash the RNA pellet by adding $1 \mathrm{ml}$ (minimum) of $75 \%$ ethanol (prepared with DEPC-treated water) per $1 \mathrm{ml}$ of TRI REAGENT used in preparation.

- (Samples can be stored in ethanol at $4{ }^{\circ} \mathrm{C}$ for 1 week and up to 1 year at $\left.20^{\circ} \mathrm{C}\right)$. 
10. Vortex the sample and centrifuge at 7,500 for 5 min at $4{ }^{\circ} \mathrm{C}$

11. Briefly dry the RNA pellet for 5-10 min by air-drying on ice.

12. Add $10-50$ ul of DEPC-water to RNA pellet. Mix at $55-60^{\circ} \mathrm{C}$ for $10-15 \mathrm{~min}$.

\section{$\underline{\text { RNA storage }}$}

Aqueous aliquots: After isolation, determine concentration using Nano drop in 10 $\mathrm{mM}$ Tris, $\mathrm{pH}$ 7.0. Freeze in $5 \mathrm{ug}, 10 \mathrm{ug}$ or $15 \mathrm{ug}$ aliquots in DEPC-water. Store at $80^{\circ} \mathrm{C}$

Ethanol aliquots: most stable. Precipitate by adding $1 / 10^{\text {th }}$ volume $1 \mathrm{M}$ sodium acetate, $\mathrm{pH} 4.8$ and 2.5 volumes of $95 \%$ ethanol. Store at $-20^{\circ} \mathrm{C}$. To retrieve: centrifuge at 7,5000 for $5 \mathrm{~min}$ at $4{ }^{\circ} \mathrm{C}$. Remove $95 \%$ ethanol from pellet and add $1 \mathrm{ml}$ of $75 \%$ ethanol. Centrifuge at 7,5000 for 5 min at $4{ }^{\circ} \mathrm{C}$. Remove ALL ethanol, briefly air dry and re-suspend in DEPC- $\mathrm{H}_{2} \mathrm{O}$. 


\section{B) Spermatozoa RNA Isolations}

\section{TRIzol Isolation with adaptations from Stallion Paper}

1. Wash spermatozoa straws in $4 \mathrm{~mL} 1 \mathrm{x}$ PBS twice at $800 \mathrm{x} g$ for 10 minutes.

- $\quad$ PBS at Room temp, water bath for spermatozoa straws at $37^{\mathrm{O}}$

2. Add $1 \mathrm{~mL}$ TRIzol reagent to spermatozoa pellet $+3 \mu \mathrm{L}$ Glycogen.

3. Lyse sample with $26 \mathrm{ga}, 6 \mathrm{cc}$ needle 20 times and incubate for 30 minutes at room temp.

4. Add $200 \mu \mathrm{L}$ chloroform per $1 \mathrm{~mL}$ TRIzol reagent to sample.

- Shake for 20 seconds then let sit at room temperature for 10 minutes.

5. Centrifuge at $12,000 \mathrm{x}$ for 15 minutes at $4^{\mathrm{O}} \mathrm{C}$.

6. Remove clear aqueous layer at top (contains RNA) and put in new tube.

7. Add $500 \mu \mathrm{L}$ ice cold isoproanol and let sit for 10 minutes on ice.

- Keep on ice for the remainder of isolation protocol.

8. Centrifuge at $12,000 \mathrm{x}$ g for 10 minutes at $4{ }^{\mathrm{O}} \mathrm{C}$.

9. Remove and discard supernatant and add $1 \mathrm{~mL} 75 \%$ ethanol to pellet.

- Vortex briefly, then centrifuge at $12,000 x \mathrm{~g}$ for 5 minutes at $4^{\mathrm{O}} \mathrm{C}$.

10. Remove supernatant and air dry pellet on ice for 5 - 10 minutes.

- After 5 minutes on ice, remove any accumulated supernatant again.

11. Heat Tris for elution to $65^{\circ} \mathrm{C}$ and add $60 \mu \mathrm{L}$ to pellet.

- Vortex until RNA pellet is dissolved in solution.

12. Nanodrop and store sample at $-80^{\circ} \mathrm{C}$.

\section{Total time expected: $\sim 3$ hours}




\section{C) Oocyte \& Embryo RNA Isolations}

(with PicoPure RNA isolation Kit)

**Clean bench well with RNase out/Zap \& wipe everything with $70 \%$ ethanol**

** No need to dump waste between samples!**

1. Aliquot $20 \mu \mathrm{l}$ of Extraction buffer (XB) into a $1.5 \mathrm{ml}$ RNase-free tube

2. Collect oocytes/embryos into the extraction buffer

3. Parafilm tube and incubate in $42^{\circ} \mathrm{C}$ waterbath for 30 minutes (do not spin).

- Stopping point: freeze on dry ice. (Our shipped samples are here)

4. Add $250 \mu \mathrm{l}$ of Conditioning buffer (CB) onto the purification column.

5. Incubate at room temperature for 5 minutes.

6. Centrifuge column at $16.0 \mathrm{rcf}$ for 1 minute

7. Add $20 \mu \mathrm{l}$ of $70 \%$ ethanol into the cell extract from step number 3 .

8. Mix well by pipetting (do not centrifuge).

9. Add the mixture onto the pre-conditioned column.

10. Centrifuge for 2 minutes at $.1 \mathrm{rcf}$

11. Centrifuge for 30 seconds at $16.0 \mathrm{rcf}$

12. Add $100 \mu 1$ of Wash Buffer 1 (W1)

13. Centrifuge for 1 minute at $8.0 \mathrm{rcf}$

14. Add $100 \mu 1$ of Wash Buffer 2 (W2)

15. Centrifuge for 1 minute at $8.0 \mathrm{rcf}$

16. Add $100 \mu 1$ of Wash Buffer 2 (W2)

17. Centrifuge for 3 minutes at $16.0 \mathrm{rcf}$

18. Add $20 \mu \mathrm{l}$ of Elution buffer (EB) to the column. 
19. Incubate for 1 minutes at room temperature

20. Centrifuge for 1 minute at $1.0 \mathrm{rcf}$

21. Centrifuge for 1 minute at $16.0 \mathrm{rcf}$

22. Nanodrop and store in $-80^{\circ} \mathrm{C}$

** Do samples separately! Get better results if samples are done separate and ** then combined and vacuumed. 


\section{D) Reverse Transcription}

\section{Superscript TM III}

\section{RT Reaction}

1. Add the following to the 10ul of ligated RNA (want [ ] 2ug + xul dH20 $=10 u l$ total)

- GeneRacer OligoDT Primers 1ul

- dNTP Mix $1 \mathrm{ul}$

- Sterile dH20 1ul

2. Incubate at $65^{\circ} \mathrm{c}$ for $5 \mathrm{~min}$ to remove and RNA secondary structure

3. Chill on ice for at least $1 \mathrm{~min}$ and centrifuge briefly

4. Add the following reagents to the 13ul ligated RNA and primer mixture:

- 5X First Strand Buffer $\quad 4 u l$

- 0.1 M DTT 1 1ul

- RNaseOutTM (40U/ul) 1ul

- SuperScriptTM III RT (200U/ul) $\underline{1 \mathrm{ul}}$

- Total 20ul

5. Mix well by pipetting up and down gently

6. Centrifuge briefly and incubate at $50^{\circ} \mathrm{c}$ for $45 \mathrm{~min}$

7. Inactivate the $\mathrm{RT}$ reaction at $70^{\circ} \mathrm{c}$ for $15 \mathrm{~min}$

8. Chill on ice for 2 min and centrifuge briefly

9. Add $1 \mathrm{ul}$ of $\mathrm{RNaseH}(2 \mathrm{U})$ to the reaction mix

10. Incubate at $37^{\circ} \mathrm{c}$ for $20 \mathrm{~min}$

Centrifuge briefly and use immediately for amplification or store at $-20^{\circ} \mathrm{C}$ 
E) Standard Polymerase Chain Reaction

- Wear gloves

- Make aliquots of kit components for own use-except for Taq

- Make sure to vortex $\mathrm{MgCl}_{2}$ well

- $\quad$ Make master mix for number of samples +1

Sample Types:

1.) cDNA from RT reaction

2.) RT negative control: no enzyme

3.) RT negative control: no template RNA

4.) PCR negative control: no template RT added

\section{PCR Reaction Master Mix:}

\begin{tabular}{|c|c|c|c|c|c|c|c|c|c|c|c|c|}
\hline Reagents & $\mathrm{x} 1$ & $\times 2$ & $\mathrm{x} 3$ & $\mathrm{x} 4$ & $\mathbf{x 5}$ & $\mathrm{x} 6$ & $\times 7$ & $\mathrm{x} 8$ & $\times 9$ & $\mathrm{x} 10$ & $\mathrm{x} 11$ & $\mathrm{x} 12$ \\
\hline Std Taq Buffer & 5 & 10 & 15 & 20 & 25 & 30 & 35 & 40 & 45 & 50 & 55 & 60 \\
\hline Forward GSP & 4 & 8 & 12 & 16 & 20 & 24 & 28 & 32 & 36 & 40 & 44 & 48 \\
\hline Reverse GSP & 4 & 8 & 12 & 16 & 20 & 24 & 28 & 32 & 36 & 40 & 44 & 48 \\
\hline $\mathrm{MgCl} 2$ & 3 & 6 & 9 & 12 & 15 & 18 & 21 & 24 & 27 & 30 & 33 & 36 \\
\hline dNTPs & 1 & 2 & 3 & 4 & 5 & 6 & 7 & 8 & 9 & 10 & 11 & 12 \\
\hline Taq & 0.5 & 1 & 1.5 & 2 & 2.5 & 3 & 3.5 & 4 & 4.5 & 5 & 5.5 & 6 \\
\hline Water & 31.5 & 63 & 94.5 & 126 & 157.5 & 189 & 220.5 & 252 & 283.5 & 315 & 346.5 & 378 \\
\hline Total Per Tube & 49 & 49 & 49 & 49 & 49 & 49 & 49 & 49 & 49 & 49 & 49 & 49 \\
\hline Template Per Tube & 1 & 1 & 1 & 1 & 1 & 1 & 1 & 1 & 1 & 1 & 1 & 1 \\
\hline
\end{tabular}

\begin{tabular}{|l|c|c|c|c|c:c:c:c:c|c:c|c|}
\hline Reagents & $\mathbf{x 1}$ & $\mathbf{x 2}$ & $\mathbf{x 3}$ & $\mathbf{x 4}$ & $\mathbf{x 5}$ & $\mathbf{x 6}$ & $\mathbf{x 7}$ & $\mathbf{x 8}$ & $\mathbf{x 9}$ & $\mathbf{x 1 0}$ & $\mathbf{x 1 1}$ & $\mathbf{x 1 2}$ \\
\hline Std Taq Buffer & 5 & 10 & 15 & 20 & 25 & 30 & 35 & 40 & 45 & 50 & 55 & 60 \\
\hdashline $\mathrm{MgCl} 2$ & 3 & 6 & 9 & 12 & 15 & 18 & 21 & 24 & 27 & 30 & 33 & 36 \\
\hdashline $\mathrm{dNTPS}$ & 1 & 2 & 3 & 4 & 5 & 6 & 7 & 8 & 9 & 10 & 11 & 12 \\
\hdashline Taq & 0.5 & 1 & 1.5 & 2 & 2.5 & 3 & 3.5 & 4 & 4.5 & 5 & 5.5 & 6 \\
\hdashline Water & 31.5 & 63 & 94.5 & 126 & 157.5 & 189 & 220.5 & 252 & 283.5 & 315 & 346.5 & 378 \\
\hline Total Per Tube & 41 & 41 & 41 & 41 & 41 & 41 & 41 & 41 & 41 & 41 & 41 & 41 \\
\hdashline Forward GSP & 4 & 4 & 4 & 4 & 4 & 4 & 4 & 4 & 4 & 4 & 4 & 4 \\
\hdashline Reverse GSP & 4 & 4 & 4 & 4 & 4 & 4 & 4 & 4 & 4 & 4 & 4 & 4 \\
\hline Template Per Tube & 1 & 1 & 1 & 1 & 1 & 1 & 1 & 1 & 1 & 1 & 1 & 1 \\
\hline
\end{tabular}


- Mix well and centrifuge

- Make sure no bubbles are present before PCR reaction

PCR conditions:

- 1 cycle: $94^{\circ} \mathrm{C}$ for $3 \mathrm{~min}$

- 35 cycles: $94^{\circ} \mathrm{C}$ for $30 \mathrm{sec}$, ${ }^{\circ} \mathrm{C}$ for $30 \mathrm{sec}, 72^{\circ} \mathrm{C}$ for $30 \mathrm{sec}$

- 1 cycle: $72^{\circ} \mathrm{C}$ for $10 \mathrm{~min}$

- Hold at $4^{\circ} \mathrm{C}$

Store at $-20^{\circ} \mathrm{C}$ until analysis

\section{MgCl2 Gradient Option:}

\begin{tabular}{|l|c|c|c|c|c|c|}
\hline Reagents & $\mathbf{x 1}$ & $\mathbf{x 2}$ & $\mathbf{x 3}$ & $\mathbf{x 4}$ & $\mathbf{x 5}$ & $\mathbf{x 6}$ \\
\hline Std Taq Buffer & 5 & 10 & 15 & 20 & 25 & 30 \\
\hline Forward GSP & 4 & 8 & 12 & 16 & 20 & 24 \\
\hline Reverse GSP & 4 & 8 & 12 & 16 & 20 & 24 \\
\hline MgCl2 & 1 & 2 & 3 & 4 & 5 & 6 \\
\hline dNTPs & 1 & 2 & 3 & 4 & 5 & 6 \\
\hline Taq & 0.5 & 1 & 1.5 & 2 & 2.5 & 3 \\
\hline Water & 33.5 & 32.5 & 31.5 & 30.5 & 29.5 & 28.5 \\
\hline Total Per Tube & 49 & 49 & 49 & 49 & 49 & 49 \\
\hline Template Per Tube & 1 & 1 & 1 & 1 & 1 & 1 \\
\hline
\end{tabular}


F) cDNA Amplification

\section{First-strand cDNA synthesis}

1. For each sample and Control Mouse Liver Total RNA, combine the following reagents in separate $0.5 \mathrm{ml}$ reaction tubes:

\begin{tabular}{ll}
$1-50 \mu \mathrm{l}$ & RNA (1-1,000 ng of total RNA)* \\
$7 \mu \mathrm{l}$ & 3' SMART CDS Primer II A $(12 \mu \mathrm{M})$ \\
$\mathbf{x} \mu \mathrm{l}$ & Deionized H2O \\
\hline $\mathbf{5 7} \boldsymbol{\mu l}$ & Total Volume
\end{tabular}

*For the control synthesis, add 10 ng of Control Mouse Liver Total RNA.

2. Mix contents and spin the tubes briefly in a microcentrifuge.

3. Incubate the tubes at $72^{\circ} \mathrm{C}$ in a hot-lid thermal cycler for $3 \mathrm{~min}$, and then cool the tubes to $42^{\circ} \mathrm{C}$.

4. Prepare a Master Mix for all reaction tubes at room temperature by combining the following reagents in the order shown:

\begin{tabular}{ll}
$20 \mu \mathrm{l}$ & 5X First-Strand Buffer \\
$2 \mu \mathrm{l}$ & DTT $(100 \mathrm{mM})$ \\
$10 \mu \mathrm{l}$ & dNTP Mix $(10 \mathrm{mM})$ \\
$7 \mu \mathrm{l}$ & SMARTer II A Oligonucleotide $(12 \mu \mathrm{M})$ \\
$5 \mu \mathrm{l}$ & RNase Inhibitor \\
$5 \mu \mathrm{l}$ & SMARTScribe \\
\hline $\mathrm{U})^{*}$ & \\
\hline
\end{tabular}

* Add to the master mix just prior to use. Mix well by vortexing \& spin down.

5. Aliquot $49 \mu \mathrm{l}$ of the Master Mix into each reaction tube. Mix the contents of the tubes by gently pipetting, and spin the tubes briefly to collect the contents at the bottom. 
6. Incubate the tubes at $42^{\circ} \mathrm{C}$ for 1 hour.

NOTE: If your downstream application requires long transcripts, extend incubation time to $90 \mathrm{~min}$.

7. Terminate the reaction by heating the tubes at $70^{\circ} \mathrm{C}$ for $10 \mathrm{~min}$.

8. If necessary, cDNA samples can be stored at $-20^{\circ} \mathrm{C}$ (for up to three months) until you are ready to proceed with spin-column purification.

\section{Column purification of cDNA using NucleoSpin gel and PCR clean-up}

1. Add $350 \mu \mathrm{l}$ of Buffer NT to each cDNA synthesis reaction; mix well by pipetting.

2. Place a NucleoSpin Gel and PCR Clean-Up Column into a $2 \mathrm{ml}$ collection tube. Pipette the sample into the column. Centrifuge at 8,000 rpm for $1 \mathrm{~min}$. Discard the flowthrough.

3. Return the column to the collection tube. Add $600 \mu \mathrm{l}$ of Wash Buffer NT3 to the column. Centrifuge at 14,000 rpm for $1 \mathrm{~min}$. Discard the flowthrough.

4. Return the column to the collection tube. Add $250 \mu \mathrm{l}$ of Wash Buffer NT3 to the column. Centrifuge at 14,000 rpm for $1 \mathrm{~min}$. Discard the flowthrough.

5. Place the column back into the collection tube. Centrifuge at $14,000 \mathrm{rpm}$ for $2 \mathrm{~min}$ to remove any residual Wash Buffer NT3.

6. Transfer the NucleoSpin Columns into a fresh $1.5 \mathrm{ml}$ microcentrifuge tube. Add $50 \mu \mathrm{l}$ of sterile Milli-Q H2O to the column. Allow the column to stand for $2 \mathrm{~min}$ with the caps open.

7. Close the tube and centrifuge at $14,000 \mathrm{rpm}$ for $1 \mathrm{~min}$ to elute the sample. 
8. Repeat elution with $35 \mu \mathrm{l}$ of sterile Milli-Q H2O in the same $1.5 \mathrm{ml}$ microcentrifuge tube. The recovered elution volume should be $80-85 \mu \mathrm{l}$ per sample. If necessary, add sterile Milli-Q H2O to bring the total volume up to $80 \mu \mathrm{l}$.

9. For PCR-Select cDNA subtraction, proceed with the protocols provided in Appendix A of this User Manual. For all other applications, proceed with Section D. Samples can be stored at $-20^{\circ} \mathrm{C}$ (for up to three months) until you are ready to proceed with cDNA amplification by LD PCR.

\section{cDNA amplification by LD PCR}

1. Preheat the PCR thermal cycler to $95^{\circ} \mathrm{C}$.

2. For each reaction, aliquot the appropriate volume (see T able II) of each diluted first-strand cDNA into a labeled $0.5 \mathrm{ml}$ reaction tube. If necessary, add deionized $\mathrm{H} 2 \mathrm{O}$ to adjust the volume to $80 \mu \mathrm{l}$.

\begin{tabular}{|c|c|c|c|}
\hline \multicolumn{4}{|c|}{ Table II: Guidelines for Setting Up PCR Reactions } \\
\hline $\begin{array}{c}\text { Total RNA } \\
(\mathrm{ng})\end{array}$ & $\begin{array}{c}\text { Volume of Diluted } \\
\text { ss cDNA for PCR } \\
(\mathrm{uL})\end{array}$ & $\begin{array}{c}\text { Volume of H20 } \\
(\mathrm{uL})\end{array}$ & $\begin{array}{c}\text { Typical Optimal No. of } \\
\text { PCR Cycles* }\end{array}$ \\
\hline 1000 & 2.5 & 77.5 & $18-20$ \\
\hline 250 & 10 & 70 & $18-20$ \\
\hline 100 & 25 & 55 & $18-20$ \\
\hline 50 & 40 & 40 & $18-20$ \\
\hline 20 & 80 & none & $19-21$ \\
\hline 5 & 80 & none & $21-23$ \\
\hline 1 & 80 & none & $24-27$ \\
\hline
\end{tabular}

3. Prepare a Master Mix for all reactions, plus one additional reaction. Combine the

\begin{tabular}{|ll}
\hline $4 \mu \mathrm{l}$ & Deionized H2O \\
$10 \mu \mathrm{l}$ & 10X Advantage 2 PCR Buffer \\
$2 \mu \mathrm{l}$ & 50X dNTP Mix (10 mM)118 \\
$2 \mu \mathrm{l}$ & 5' PCR Primer II A $(12 \mu \mathrm{M})$ \\
$\underline{2 \mu \mathrm{l}}$ & 50X Advantage 2 Polymerase \\
\hline$\underline{\text { Mix }}$ &
\end{tabular}
following reagents in the order 
shown:

4. Mix well by vortexing and spin the tube briefly in a microcentrifuge.

5. Aliquot $20 \mu \mathrm{l}$ of the PCR Master Mix into each tube from Step 2.

6. Cap the tube, and place it in the preheated thermal cycler. If you are NOT using a hot-lid thermal cycler, overlay the reaction mixture with two drops of mineral oil.

\begin{tabular}{|c|c|c|}
\hline \multicolumn{2}{|c|}{ Table III: Cycling Guidelines Based on Starting Material } \\
\hline No. of Cells & Typical No. of \\
(e.g. HeLa) & Typical Yield of Total RNA (ng) & PCR Cycles \\
\hline$\sim 10$ & 0.15 & 27 \\
\hline$\sim 100$ & 1.5 & 24 \\
\hline$\sim 1,000$ & 15 & 20 \\
\hline$\sim 10,000$ & $150^{*}$ & 18 \\
\hline
\end{tabular}

7. Commence thermal cycling using the following program:

- $95^{\circ} \mathrm{C} 1 \mathrm{~min}$ 
- $\mathrm{X}$ cycles at: $95^{\circ} \mathrm{C} 15 \mathrm{sec}$

$65^{\circ} \mathrm{C} 30 \mathrm{sec}$

$68^{\circ} \mathrm{C} 3 \mathrm{~min}$

a) Consult Tables II \& III for guidelines. Subject all tubes to 15 cycles. Then, divide the PCR reaction mix between the "Experimental" and "Optimization" tubes, using the Optimization tube for each reaction to determine the optimal number of PCR cycles, as described in Step 8.

b) For applications requiring longer cDNA transcripts, increase to 6 min.

8. Subject each reaction tube to 15 cycles, then pause the program. Transfer $30 \mu 1$ from each tube to a second reaction tube labeled "Optimization". Store the "Experimental" tubes at $4^{\circ} \mathrm{C}$. Using the Tester PCR tube, determine the optimal number of PCR cycles (see Figure 3):

a) Transfer $5 \mu$ from the 15 cycle PCR reaction tube to a clean microcentrifuge tube (for agarose/EtBr gel analysis).

b) Return the Optimization tubes to the thermal cycler. Run three additional cycles (for a total of 18) with the remaining $25 \mu 1$ of PCR mixture.

c) Transfer $5 \mu \mathrm{l}$ from the 18 cycle PCR reaction tube to a clean microcentrifuge tube (for agarose/EtBr gel analysis).

d) Run three additional cycles (for a total of 21) with the remaining $20 \mu$ of PCR mixture.

e) Transfer $5 \mu$ from the 21 cycle PCR to a clean microcentrifuge tube (for agarose/EtBr gel analysis). 
f) Run three additional cycles (for a total of 24) with the remaining $15 \mu \mathrm{l}$ of PCR mixture.

g) Transfer $5 \mu$ from the 24 cycle PCR to a clean microcentrifuge tube (for agarose/EtBr gel analysis).

h) Run three additional cycles (for a total of 27) with the remaining $10 \mu \mathrm{l}$ of PCR mixture.

i) Transfer $5 \mu \mathrm{l}$ from the 27 cycle PCR to a clean microcentrifuge tube (for agarose/EtBr gel analysis).

j) Run three additional cycles (for a total of 30) with the remaining $5 \mu \mathrm{l}$ of PCR mixture.

9. Electrophorese each $5 \mu \mathrm{l}$ aliquot of the PCR reaction alongside $0.1 \mu \mathrm{g}$ of $1 \mathrm{~kb}$ DNA size markers on a $1.2 \%$ agarose/EtBr gel in $1 \mathrm{X}$ TAE buffer. Determine the optimal number of cycles required for each experimental and control sample (see Figure 4, Section VI).

10. Retrieve the 15 cycle Experimental PCR tubes from $4{ }^{\circ} \mathrm{C}$, return them to the thermal cycler, and subject them to additional cycles, if necessary, until you reach the optimal number.

11. When the cycling 11 . is completed, analyze a $5 \mu$ sample of each PCR product alongside $0.1 \mu \mathrm{g}$ of $1 \mathrm{~kb}$ DNA size markers on a $1.2 \%$ agarose/EtBr gel in $1 \mathrm{X}$ TAE buffer. Compare your results to Figure 4 to confirm that your reactions were successful.

12. Add $2 \mu 1$ of $0.5 \mathrm{M}$ EDTA to each tube to terminate the reaction. 


\section{Column purification of PCR products using NucleoSpin gel and PCR clean-up}

1. Add $300 \mu \mathrm{l}$ Binding NT Buffer to each $70 \mu \mathrm{l}$ PCR reaction. Mix well by pipetting.

2. Place a NucleoSpin column into a $2 \mathrm{ml}$ Collection Tube, and pipette the sample onto the filter. Centrifuge at $8,000 \mathrm{rpm}$ for $1 \mathrm{~min}$. Discard the Collection Tube and flowthrough.

3. Insert the NucleoSpin column into a fresh $2 \mathrm{ml}$ Collection Tube. Add $600 \mu \mathrm{l}$ Wash Buffer NT3 to the column. Centrifuge at 14,000 rpm for $1 \mathrm{~min}$. Discard the flowthrough.

4. Return the column to the Collection Tube. Add $250 \mu \mathrm{l}$ Wash Buffer NT3 to the column. Centrifuge at 14,000 rpm for $1 \mathrm{~min}$. Discard the flowthrough.

5. Discard the flowthrough and spin again at $14,000 \mathrm{rpm}$ for $1 \mathrm{~min}$ to remove the final traces of ethanol to dry the filter.

6. Transfer the NucleoSpin column to a clean $1.5 \mathrm{ml}$ microcentrifuge tube. Pipette $50 \mu$ Elution Buffer NE directly onto the filter, being careful not to touch the surface of the filter with the tip of the pipette. Allow the filter to soak for 2 min with the lid open.

7. Close the tube and centrifuge at $14,000 \mathrm{rpm}$ for $1 \mathrm{~min}$ to elute PCR product. Save the column.

8. Determine the yield of each PCR product by measuring the A260. For each reaction, we usually obtain $1-2 \mu \mathrm{g}$ of SMARTer cDNA after purification.

9. If no product is detected, perform elution (Steps 6 and 7) a second time, using a fresh $1.5 \mathrm{ml}$ microcentrifuge tube. 
G) Rapid Amplification of cDNA Ends Polymerase Chain Reaction

\section{Use 1-5 ug Total RNA}

\section{Dephosphorylating RNA}

\section{$\sim 1$ Hour}

1. Set up on ice the following $10 \mu \mathrm{l}$ dephosphorylation reaction in a $1.5 \mathrm{ml}$ sterile microcentrifuge tube using the reagents in the kit. Use 1-5 $\mu \mathrm{g}$ total RNA or 50250 ng mRNA.

\begin{tabular}{|l|l|l|}
\hline \multicolumn{1}{|c|}{ Reagent } & Sample RNA & Control RNA \\
\hline RNA & $\mathrm{x} \mu \mathrm{l}$ & $2 \mu \mathrm{l}$ \\
\hline $10 \mathrm{XCIP}$ Buffer & $1 \mu \mathrm{l}$ & $1 \mu \mathrm{l}$ \\
\hline RNaseOut ${ }^{\mathrm{v}}(40 \mathrm{U} / \mu \mathrm{l})$ & $1 \mu \mathrm{l}$ & $1 \mu \mathrm{l}$ \\
\hline $\mathrm{CIP}(10 \mathrm{U} / \mu \mathrm{l})$ & $1 \mu \mathrm{l}$ & $1 \mu \mathrm{l}$ \\
\hline DEPC water & $\mathrm{y} \mu \mathrm{l}$ & $5 \mu \mathrm{l}$ \\
\hline Total Volume & $10 \mu \mathrm{l}$ & $10 \mu \mathrm{l}$ \\
\hline
\end{tabular}

2. Mix gently by pipetting and vortex briefly. Centrifuge to collect fluid.

3. Incubate at $50^{\circ} \mathrm{C}$ for 1 hour. After incubation, centrifuge briefly and place on ice.

\section{Precipitating RNA}

\section{〜5 minutes}

1. To precipitate RNA, add $90 \mu \mathrm{l}$ DEPC water and $100 \mu \mathrm{l}$ phenol:chloroform and vortex vigorously for 30 seconds. 
2. Centrifuge at maximum speed for 5 minutes at room temperature.

3. Transfer aqueous (top) phase to a new microcentrifuge tube $(\sim 100 \mu \mathrm{l})$.

4. Add $2 \mu 10 \mathrm{mg} / \mathrm{ml}$ mussel glycogen, $10 \mu \mathrm{l} 3 \mathrm{M}$ sodium acetate, $\mathrm{pH}$ 5.2, and mix well. Add $220 \mu 1$ 95\% ethanol and vortex briefly.

5. Freeze on dry ice for 10 minutes. You may proceed to the next step or store at $20^{\circ} \mathrm{C}$ overnight.

- Note: Do not store the RNA in DEPC water. Store RNA in ethanol at $20^{\circ} \mathrm{C}$.

6. To pellet RNA, centrifuge at maximum speed in a microcentrifuge for 20 minutes at $+4^{\circ} \mathrm{C}$.

7. Note the position of the pellet and remove the supernatant by pipet. Be careful not to disturb pellet.

8. Add $500 \mu \mathrm{l} 70 \%$ ethanol, invert several times, and vortex briefly.

9. Centrifuge at maximum speed in a microcentrifuge for 2 minutes at $+4^{\circ} \mathrm{C}$.

10. Note the position of the pellet and carefully remove the ethanol using a pipet. Centrifuge again to collect remaining ethanol.

11. Carefully remove the remaining ethanol by pipet and air-dry the pellet for 1-2 minutes at room temperature.

12. Resuspend the pellet in $7 \mu \mathrm{l}$ DEPC water. If you want to check the stability of RNA after the CIP reaction, resuspend the pellet in $8 \mu \mathrm{LEPC}$ water and analyze $1 \mu$ l by agarose gel electrophoresis. Proceed to Removing the mRNA

\section{Cap Structure.}




\section{Decapping Reaction}

1 hour

1. Set up on ice the $10 \mu \mathrm{l}$ decapping reaction in a $1.5 \mathrm{ml}$ sterile microcentrifuge tube using the reagents in the kit.

- Dephosphorylated RNA $7 \mu \mathrm{l}$

- $10 X$ TAP Buffer $1 \mu \mathrm{l}$

- $\mathrm{RNaseOut}^{\mathrm{TM}}(40 \mathrm{U} / \mu \mathrm{l}) \quad 1 \mu \mathrm{l}$

- $\operatorname{TAP}(0.5 \mathrm{U} / \mu \mathrm{l}) \quad 1 \mu \mathrm{l}$

- Total Volume $\quad 10 \mu \mathrm{l}$

2. Mix gently by pipetting and vortex briefly. Centrifuge briefly to collect fluid.

3. Incubate at $37^{\circ} \mathrm{C}$ for 1 hour.

4. After incubation, centrifuge briefly and place on ice.

5.

\section{Precipitating RNA}

〜5 Minutes

1. To precipitate RNA, add $90 \mu \mathrm{l}$ DEPC water and $100 \mu \mathrm{l}$ phenol:chloroform and vortex vigorously for 30 seconds.

2. Centrifuge at maximum speed in a microcentrifuge for 5 minutes at room temperature.

3. Transfer aqueous (top) phase to a new microcentrifuge tube $(\sim 100 \mu \mathrm{l})$.

4. Add $2 \mu \mathrm{l} 10 \mathrm{mg} / \mathrm{ml}$ mussel glycogen, $10 \mu \mathrm{l} 3 \mathrm{M}$ sodium acetate, $\mathrm{pH} 5.2$, and mix well. Add $220 \mu \mathrm{l} 95 \%$ ethanol and vortex briefly. 
5. Freeze on dry ice for 10 minutes. You may proceed to the next step or store at $20^{\circ} \mathrm{C}$ overnight.

- Note: Do not store the RNA in DEPC water. Store RNA in ethanol at $20^{\circ} \mathrm{C}$.

6. To pellet RNA, centrifuge at maximum speed in a microcentrifuge for 20 minutes at $+4^{\circ} \mathrm{C}$.

7. Note the position of the pellet and remove the supernatant by pipet. Be careful not to disturb pellet.

8. Add $500 \mu 170 \%$ ethanol, invert several times, and vortex briefly.

9. Centrifuge at maximum speed in a microcentrifuge for 2 minutes at $+4^{\circ} \mathrm{C}$.

10. Note the position of the pellet and carefully remove the ethanol using a pipet. Centrifuge again to collect remaining ethanol.

11. Carefully remove the remaining ethanol by pipet and air-dry the pellet for 1-2 minutes at room temperature.

12. Resuspend the pellet in $7 \mu \mathrm{l}$ DEPC water. If you want to check the stability of RNA after the CIP reaction, resuspend the pellet in $8 \mu \mathrm{l}$ DEPC water and analyze $1 \mu \mathrm{l}$ by agarose gel electrophoresis. Proceed directly to Ligating the RNA Oligo to Decapped mRNA.

13.

\section{Ligation Reaction}

\section{$\sim 1$ hour 10 minutes}

1. Add $7 \mu \mathrm{l}$ of dephosphorylated, decapped RNA to the tube containing the prealiquoted, lyophilized GeneRacer ${ }^{\mathrm{TM}}$ RNA Oligo $(0.25 \mu \mathrm{g})$. Pipet up and down 
several times to mix and resuspend RNA Oligo. Centrifuge briefly to collect the fluid in the bottom of the tube.

2. Incubate at $65^{\circ} \mathrm{C}$ for 5 minutes to relax the RNA secondary structure.

- Note: After the incubation, the total volume of this solution may decrease by $1 \mu \mathrm{l}$ due to evaporation.

3. Place on ice to chill ( 2 minutes) and centrifuge briefly.

4. Add the following reagents to the tube, mix gently by pipetting, and centrifuge briefly.

- 10X Ligase Buffer $\quad 1 \mu \mathrm{l}$

- 10 mM ATP $1 \mu \mathrm{l}$

- $\operatorname{RNaseOut}^{\mathrm{TM}}(40 \mathrm{U} / \mu \mathrm{l}) \quad 1 \mu \mathrm{l}$

- $\quad$ T4 RNA ligase $(5 \mathrm{U} / \mu \mathrm{l}) \quad 1 \mu \mathrm{l}$

- Total Volume $10 \mu \mathrm{l}$

5. Incubate at $37^{\circ} \mathrm{C}$ for 1 hour. Centrifuge briefly and place on ice. Precipitate the RNA.

\section{Precipitating RNA}

\section{$\sim 45$ minutes}

1. To precipitate RNA, add $90 \mu \mathrm{l}$ DEPC water and $100 \mu \mathrm{l}$ phenol:chloroform and vortex vigorously for 30 seconds.

2. Centrifuge at maximum speed in a microcentrifuge for 5 minutes at room temperature. 
3. Transfer aqueous (top) phase to a new microcentrifuge tube $(\sim 100 \mu \mathrm{l})$.

4. Add $2 \mu \mathrm{l} 10 \mathrm{mg} / \mathrm{ml}$ mussel glycogen, $10 \mu \mathrm{l} 3 \mathrm{M}$ sodium acetate, $\mathrm{pH} 5.2$, and mix well. Add $220 \mu 195 \%$ ethanol and vortex briefly.

5. Freeze on dry ice for 10 minutes. You may proceed to the next step or store at $20^{\circ} \mathrm{C}$ overnight.

- Note: Do not store the RNA in DEPC water. Store RNA in ethanol at $20^{\circ} \mathrm{C}$.

6. To pellet RNA, centrifuge at maximum speed in a microcentrifuge for 20 minutes at $+4^{\circ} \mathrm{C}$.

7. Note the position of the pellet and remove the supernatant by pipet. Be careful not to disturb pellet.

8. Add $500 \mu \mathrm{l} 70 \%$ ethanol, invert several times, and vortex briefly.

9. Centrifuge at maximum speed in a microcentrifuge for 2 minutes at $+4^{\circ} \mathrm{C}$.

10. Note the position of the pellet and carefully remove the ethanol using a pipet. Centrifuge again to collect remaining ethanol.

11. Carefully remove the remaining ethanol by pipet and air-dry the pellet for 1-2 minutes at room temperature.

12. Resuspend the pellet in $7 \mu \mathrm{LEPC}$ water. If you want to check the stability of RNA after the CIP reaction, resuspend the pellet in $8 \mu$ DEPC water and analyze $1 \mu \mathrm{l}$ by agarose gel electrophoresis. Proceed to Reverse Transcribing mRNA. 


\section{Reverse Transcribing mRNA (Superscript III RT Reaction)}

\section{$\sim 2$ Hours}

1. Add the following to the $10 \mu \mathrm{l}$ of ligated RNA from Step 12:

- Primers $1 \mu \mathrm{l}$

- dNTP Mix $1 \mu \mathrm{l}$

- Sterile, distilled water $1 \mu \mathrm{l}$

2. Incubate at $65^{\circ} \mathbf{C}$ for $\mathbf{5}$ minutes to remove any RNA secondary structure.

3. Chill on ice for at least 1 minute and centrifuge briefly.

4. Add the following reagents to the $13-\mu l$ ligated RNA and primer mixture:

- 5X First Strand Buffer $\quad 4 \mu 1$

- $0.1 \mathrm{M} \mathrm{DTT} \quad 1 \mu \mathrm{l}$

- $\operatorname{RNaseOut}^{\mathrm{TM}}(40 \mathrm{U} / \mu \mathrm{l}) \quad 1 \mu \mathrm{l}$

- $\quad$ SuperScript ${ }^{\mathrm{TM}}$ III RT (200 U/ $\left.\mu \mathrm{l}\right) 1 \mu \mathrm{l}$

- Total Volume $20 \mu \mathrm{l}$

5. Mix well by pipetting gently up and down.

- Note: If you are using random primers, incubate the reaction mix at $25^{\circ} \mathrm{C}$ for 5 minutes prior to Step 6 to allow efficient binding of the random primers to the template.

6. Centrifuge briefly and incubate at $50^{\circ} \mathrm{C}$ for $30-60$ minutes. If you are using gene-specific primers, increase the reaction temperature to $55^{\circ} \mathrm{C}$.

7. Inactivate the $\mathrm{RT}$ reaction at $70^{\circ} \mathrm{C}$ for 15 minutes. Chill on ice for 2 minutes and centrifuge briefly at maximum speed in a microcentrifuge. 
8. Add $1 \mu$ l of RNase $\mathrm{H}(2 \mathrm{U})$ to the reaction mix.

9. Incubate at $37^{\circ} \mathrm{C}$ for 20 minutes.

10. Centrifuge briefly and use immediately for amplification or store at $-20^{\circ} \mathrm{C}$.

You may use up to $2 \mu \mathrm{l}$ of the RT reaction in each PCR reaction.

\section{Nested PCRs with GSPs}

\begin{tabular}{|c|c|c|c|c|c|c|c|c|c|c|c|c|c|}
\hline \multicolumn{2}{|c|}{ PCR 1 of 2} & \multicolumn{6}{|c|}{ 5' RACE } & \multicolumn{6}{|c|}{ 3' RACE } \\
\hline Reagent & Concentration & $1 x$ & $2 x$ & $3 x$ & $4 x$ & $5 x$ & $6 x$ & $1 x$ & $2 x$ & $3 x$ & $4 x$ & $5 x$ & $6 x$ \\
\hline Generacer 5' Primer & $10 \mathrm{uM}$ & 3 & 6 & 9 & 12 & 15 & 18 & & & & & & \\
\hline Reverse GSP & $2.5 \mathrm{um}$ & 4 & 8 & 12 & 16 & 20 & 24 & & & & & & \\
\hline Generacer 3' Primer & $10 \mathrm{uM}$ & & & & & & & 3 & 6 & 9 & 12 & 15 & 18 \\
\hline Forward GSP & $2.5 \mathrm{uM}$ & & & & & & & 4 & 8 & 12 & 16 & 20 & 24 \\
\hline RT Template & -- & 1 & 2 & 3 & 4 & 5 & 6 & 1 & 2 & 3 & 4 & 5 & 6 \\
\hline 10X PCR Buffer & $10 \mathrm{x}$ & 5 & 10 & 15 & 20 & 25 & 30 & 5 & 10 & 15 & 20 & 25 & 30 \\
\hline dNTPs & $10 \mathrm{mM}$ each & 1 & 2 & 3 & 4 & 5 & 6 & 1 & 2 & 3 & 4 & 5 & 6 \\
\hline $\mathrm{Taq}$ & $5 \mathrm{U} / \mathrm{uL}$ & 0.5 & 1 & 1.5 & 2 & 2.5 & 3 & 0.5 & 1 & 1.5 & 2 & 2.5 & 3 \\
\hline $\mathrm{MgCl} 2$ & $25 \mathrm{mM}$ & 3 & 6 & 9 & 12 & 15 & 18 & 3 & 6 & 9 & 12 & 15 & 18 \\
\hline Water & -- & 32.5 & 65 & 97.5 & 130 & 162.5 & 195 & 32.5 & 65 & 97.5 & 130 & 162.5 & 195 \\
\hline
\end{tabular}

PCR 1 of 2 Conditions

\begin{tabular}{|c|c|c|}
\hline Temperature & Time & Cy \\
\hline 94 & 2 minutes. & 1 \\
\hline 94 & 30 seconds & \\
\hline 72 & $1 \mathrm{~min} / 1 \mathrm{~kb}$ DNA & \\
\hline 94 & 30 seconds & \\
\hline 70 & $1 \mathrm{~min} / 1 \mathrm{~kb}$ DNA & \\
\hline 94 & 30 seconds & \\
\hline $60-68$ & 30 seconds & 20 \\
\hline $68-72$ & $1 \mathrm{~min} / 1 \mathrm{~kb}$ DNA & \\
\hline $68-72$ & $10 \mathrm{r}$ & 1 \\
\hline
\end{tabular}

\begin{tabular}{|c|c|c|c|c|c|c|c|c|c|c|c|c|c|}
\hline \multicolumn{2}{|c|}{ PCR 2 of 2: Nested } & \multicolumn{6}{|c|}{ 5' RACE } & \multicolumn{6}{|c|}{ 3' RACE } \\
\hline Reagent & Concentration & $1 x$ & $2 x$ & $3 x$ & $4 x$ & $5 x$ & $6 x$ & $1 x$ & $2 \mathrm{x}$ & $3 x$ & $4 x$ & $5 x$ & $6 x$ \\
\hline Generacer 5' Primer & $10 \mathrm{uM}$ & 1 & 2 & 3 & 4 & 5 & 6 & & & & & & \\
\hline Reverse GSP & $2.5 \mathrm{uM}$ & 4 & 8 & 12 & 16 & 20 & 24 & & & & & & \\
\hline Generacer 3' Primer & $10 \mathrm{uM}$ & & & & & & & 1 & 2 & 3 & 4 & 5 & 6 \\
\hline Forward GSP & $2.5 \mathrm{uM}$ & & & & & & & 4 & 8 & 12 & 16 & 20 & 24 \\
\hline Initial PCR & -- & 1 & 2 & 3 & 4 & 5 & 6 & 1 & 2 & 3 & 4 & 5 & 6 \\
\hline 10X PCR Buffer & $10 \mathrm{x}$ & 5 & 10 & 15 & 20 & 25 & 30 & 5 & 10 & 15 & 20 & 25 & 30 \\
\hline dNTPs & $10 \mathrm{mM}$ each & 1 & 2 & 3 & 4 & 5 & 6 & 1 & 2 & 3 & 4 & 5 & 6 \\
\hline Taq & $5 \mathrm{U} / \mathrm{uL}$ & 0.5 & 1 & 1.5 & 2 & 2.5 & 3 & 0.5 & 1 & 1.5 & 2 & 2.5 & 3 \\
\hline $\mathrm{MgCl} 2$ & $25 \mathrm{mM}$ & 3 & 6 & 9 & 12 & 15 & 18 & 3 & 6 & 9 & 12 & 15 & 18 \\
\hline Water & $-\cdots$ & 34.5 & 69 & 103.5 & 138 & 172.5 & 207 & 34.5 & 69 & 103.5 & 138 & 172.5 & 207 \\
\hline
\end{tabular}


Nested PCR 2 of 2 Conditions

Temperature Time Cycles

94 minutes 1

$94 \quad 30$ seconds

$65 \quad 30$ seconds $15-25$

$68 \quad 2$ minutes

68 10 minutes 1 


\section{H) Primer Dilution from IDT}

$\underline{\text { To make freezer stock: }}$

1. Spin down tubes

2. Add $\mathrm{dH}_{2} 0$ water to $50 \mu \mathrm{M}(50$ pmoles/ul)

- Divide amount of oligo in nMoles by $50 \mu \mathrm{M}$

- $\quad$ Typical volumes range from 300- $800 \mu \mathrm{l}$

3. Vortex well

4. Store at $-20^{\circ} \mathrm{C}$

5. Note primer location on Primer Inventory Sheet

To make $10 \mu \mathrm{M}$ PCR Stock:

$100 \mu \mathrm{l}$ of $50 \mu \mathrm{M}$ primer

$400 \mu \mathrm{l}$ of $\mathrm{dH}_{2} \mathrm{O}$

Store at $-20^{\circ} \mathrm{C}$

To make $2.5 \mu \mathrm{M}$ working PCR stock

$125 \mu \mathrm{l}$ of $10 \mu \mathrm{M}$ primer

$375 \mu \mathrm{l}$ of $\mathrm{dH}_{2} \mathrm{O}$

Store at $-20^{\circ} \mathrm{C}$ 


\section{I) Gel Extraction Protocol}

1.) Excise the DNA fragment from the agarose gel with a clean, sharp scalpel. Minimize the size of the gel slice by removing extra agarose.

2.) Weigh the gel slice in a colorless tube. Add 3 volumes of Buffer QG to 1 volume of gel (100mg 100 ul).

3.) Incubate at $50^{\circ} \mathrm{C}$ for $10 \mathrm{~min}$ (or until the gel slice has completely dissolved). Vortex the tube every 2-3 min during the incubation to mix.

4.) After the gel slice has dissolved completely, check that the color of the mixture is yellow.

5.) Add 1 gel volume of isopropanol to the sample and mix.

6.) Place a QIAquick spin column in a provided $2 \mathrm{ml}$ collection tube (already done).

7.) To bind DNA, apply the sample to the QIAquick column, and centrifuge for $1 \mathrm{~min}$. The maximum volume of the column reservoir is $800 \mathrm{ul}$. For sample volumes of more than 800 ul, simply load and spin again.

8.) Discard flow-through and place QIAquick column back in the same collection tube.

9.) Add 500ul of Buffer QG to QIAquick column and centrifuge for $1 \mathrm{~min}$. This step will remove all traces of agarose.

10.) To wash, add 750ul of Buffer PE to QIAquick column and centrifuge for 1 $\min$.

11.) Discard flow-through and centrifuge the QIAquick column for an extra $1 \mathrm{~min}$ at $\geq 10,000 \mathrm{X} \mathrm{g}(\sim 13,000 \mathrm{rpm})$.

12.) Place a QIAquick column into a clean $1.5 \mathrm{ml}$ microcentrifuge tube. 
13.) To elute DNA, add $50 \mathrm{ul}$ autoclaved $\mathrm{H} 2 \mathrm{O}$ to the center of the QIAquick membrane and centrifuge the column for $1 \mathrm{~min}$ at maximum speed.

14.) Reapply the flow-through and centrifuge again for $1 \mathrm{~min}$.

15.) Check concentration of samples by nanodrop or running a $2 \%$ agarose gel **Store samples at $-20^{\circ} \mathrm{C} * *$ 


\section{J) Sequencing}

Following URI GSC Instructions:

Target amounts for dsDNA templates:

- PCR products: 2.5 ng DNA per 100 bases per reaction

- Plasmids: $300-500$ ng DNA per reaction

Primer amount:

- Use one primer only; either forward or reverse, but not both!

- 5 pmol per reaction (Note: $5 \mathrm{pmol}=2.0 \mu \mathrm{l}$ of a $2.5 \mu \mathrm{M}$ stock)

Single sample volume:

- $12 \mu \mathrm{l}$ per reaction; add template plus one primer in the amounts above to MB grade water.

To facilitate pipetting, submit your sample in duplicate with a total volume of $24 \mu 1$. Submit your template and primer combined in a 0.5 or $1.5 \mathrm{ml}$ tube. DO NOT submit samples in individual $0.2 \mathrm{ml}(200 \mu \mathrm{l})$ tubes. When submitting 16 or more samples, please submit them in 8-tube strip-tube(s) (capped) or a 96-well plate (capped or sealed). 
Sample Analysis:

Sequencing on the ABI 3130xl genetic analyzer is routinely conducted using POP7 polymer, a $50 \mathrm{~cm}$. 16-capillary array and the KB Basecaller software. These conditions normally produce high quality sequence that extends to $800-1,000$ bases.

PCR products less than 900 bp in length will be analyzed in the 3130xl using an analytical protocol that looks for the end of the raw data. Please identify your PCR product and its size on the Submission Form so this protocol may be specified during instrument setup. 
K) RNA-Sequencing Protocols

\section{Protocol for Gene Ontology (GO) Analysis}

- Logon to the DAVID database ( http://david.abcc.ncifcrf.gov/)

- Select "Start Analysis" from top menu

- Copy transcript list of interest into the "Paste a list" box

- Use Genbank IDs from RNA-Seq study

○ For the "Select Identifier" box, choose appropriate type of sample accession submitted

- Use “GENBANK_ACCESSION” for RNA-Seq study

○ List Type: "Gene List"

○ Hit "Submit List"

- Select species "Bos taurus"

- On right, choose "Functional Annotation Tool"

- Click "Gene_Ontology"

○ Should automatically have "GOTERM_BP_FAT," “GOTERM_CC_FAT," “GOTERM_MF_FAT" selected

- Click "Chart" next to each checked box

- Click "Download File" in top right corner

- Copy entire window into a .txt file and save

- Open the .txt file with excel, which should automatically insert tab delimiters

- Can sort file according to target information 


\section{Getting official gene symbols \& long names from accession numbers}

- Logon to the DAVID database ( http://david.abcc.ncifcrf.gov/)

- Select "Start Analysis" from top menu

- Copy transcript list of interest into the "Paste a list" box

- Use Genbank IDs from RNA-Seq study

- For the "Select Identifier" box, choose appropriate type of sample accession submitted

- Use "GENBANK_ACCESSION" for RNA-Seq study

○ List Type: "Gene List"

○ Hit "Submit List"

- On top menu, click "Shortcut to DAVID Tools"

- Click "Gene ID Conversion"

- Select "OFFICIAL_GENE_SYMBOL" from drop down menu

- Click "Submit to Conversion Tool"

- Click "Download File" in top right corner

- Copy entire window into a .txt file and save

- Open the .txt file with excel, which should automatically insert tab delimiters

- Can sort file according to target information

\section{Pairing gene symbols \& long names with known accessions}

- Open file that you're annotating these names onto, referred to here as "FILE 1"

\begin{tabular}{|l|l|}
\hline \hline & \multicolumn{1}{|c|}{ A } \\
\hline 1 & Genbank ID \\
\hline 2 & AY646356 \\
\hline 3 & BC108207 \\
\hline 4 & BC102216 \\
\hline
\end{tabular}


- Open file with accessions/official gene IDs/long names in it, referred to here as "FILE 2"

\begin{tabular}{|c|c|c|c|c|}
\hline 1 & A & B & C & D \\
\hline 1 & AY646356 & $\underline{\text { PLCZ1 }}$ & Bos taurus & phospholipase C, zeta 1 \\
\hline 2 & AB099079 & LOC782924 & Bos taurus & similar to elongation factor 1 alpha \\
\hline 3 & BC108207 & PRM1 & Bos taurus & protamine 1 \\
\hline 4 & BC102713 & GTSF1 & Bos taurus & gametocyte specific factor 1 \\
\hline 5 & BC102216 & PSMA1 & Bos taurus & proteasome (prosome, macropain) subunit, alpha type, 1 \\
\hline 6 & AB098752 & LOC782525 & Bos taurus & eukaryotic translation elongation factor 1 gamma \\
\hline 7 & AB098752 & EEF1G & Bos taurus & eukaryotic translation elongation factor 1 gamma \\
\hline 8 & BC112491 & GSTM3 & Bos taurus & glutathione S-transferase mu 3 (brain) \\
\hline 9 & BC109790 & Hmgb4 & Bos taurus & high-mobility \\
\hline
\end{tabular}

- Temporarily copy all the information from "FILE 2" into blank columns to the right of the data in "FILE 1"

- In "FILE 1," add two additional columns to the right of the Genbank ID column

- Title one "Gene ID" and the other "Long Name"

\begin{tabular}{|c|c|c|c|c|c|c|c|c|}
\hline 4 & A & B & C & D & $\mathrm{E}$ & $\mathrm{F}$ & G & H \\
\hline 1 & Genbank ID & Gene ID & Long Name & & AY646356 & $\underline{\mathrm{PLCZ1}}$ & Bos taurus & phospholipase C, zeta 1 \\
\hline 2 & AY646356 & & & & AB099079 & LOC782924 & Bos taurus & similar to elongation factor 1 alpha \\
\hline 3 & BC108207 & & & & $\mathrm{BC} 108207$ & PRM1 & Bos taurus & protamine 1 \\
\hline 5 & & & & & BC102216 & $\underline{\text { PSMA1 }}$ & Bos taurus & proteasome (prosome, macropain) subunit, alpha type, 1 \\
\hline 6 & & & & & AB098752 & LOC782525 & Bos taurus & eukaryotic translation elongation factor 1 gamma \\
\hline 9 & & & & & BC109790 & Hmgb4 & Bos taurus & high-mobility \\
\hline
\end{tabular}

- One cell to the right of the first accession number (B2), type

$$
\text { "=VLOOKUP(A2,\$E\$1:\$H\$9, 2, FALSE)" }
$$

\begin{tabular}{|c|c|c|c|c|c|c|c|c|}
\hline 1 & A & B & C & D & $\mathrm{E}$ & $\mathrm{F}$ & G & $\mathrm{H}$ \\
\hline 1 & Genbank ID & Gene ID & Long Name & & AY 646356 & $\underline{\mathrm{PLCZ1}}$ & Bos taurus & phospholipase C, zeta 1 \\
\hline 2 & AY 646356 & \multicolumn{4}{|c|}{$=\mathrm{VLOOKUP}(\mathrm{A} 2$, SE\$1:\$H\$9, 2, FALSE) } & LOC782924 & Bos taurus & similar to elongation factor 1 alpha \\
\hline 3 & BC108207 & & & & BC108207 & PRM1 & Bos taurus & protamine 1 \\
\hline 5 & & & & & BC102216 & PSMA1 & Bos taurus & proteasome (prosome, macropain) subunit, alpha type, 1 \\
\hline 6 & & & & & AB098752 & LOC782525 & Bos taurus & eukaryotic translation elongation factor 1 gamma \\
\hline 9 & & & & & BC109790 & Hmgb4 & Bos taurus & high-mobility \\
\hline
\end{tabular}


○ $\$ \mathrm{E} \$ 1: \$ H \$ 100$

highlighting the entire table you're taking

information

from, with $\$$ signs added to lock the entire thing

in place

for when you start dragging it

$\circ 2$

column number in the table you' re searching in

containing

the information you're looking for

○ FALSE

to tell it to search for a perfect match to the

accession only

- Copy this EXACT formula into cell under "Long Name", but change column 2

to column 4 , in this example.

\begin{tabular}{|c|c|c|c|c|c|c|c|c|}
\hline 14 & A & B & C & D & $\mathrm{E}$ & $\mathrm{F}$ & G & H \\
\hline 1 & Genbank ID & Gene ID & Long Name & & AY 646356 & $\underline{P L C Z 1}$ & Bos taurus & phospholipase C, zeta 1 \\
\hline 2 & AY646356 & PLCZ1 & $=$ VLOOKUP(A & $2, \$ E \$ 1:$ & \$H\$9, 4, FAL & ALSE) & Bos taurus & similar to elongation factor 1 alpha \\
\hline 3 & BC108207 & & & & BC108207 & PRM1 & Bos taurus & protamine 1 \\
\hline 5 & & & & & BC102216 & PSMA1 & Bos taurus & proteasome (prosome, macropain) subunit, alpha type, 1 \\
\hline 6 & & & & & AB098752 & $\underline{\text { LOC782525 }}$ & Bos taurus & eukaryotic translation elongation factor 1 gamma \\
\hline 9 & & & & & BC109790 & Hmgb4 & Bos taurus & high-mobility \\
\hline
\end{tabular}

- Drag down to fill in the remainder of the accessions from column A

\begin{tabular}{|c|c|c|c|c|c|c|c|c|}
\hline 4 & A & B & C & D & E & $\mathrm{F}$ & G & $\mathrm{H}$ \\
\hline 1 & Genbank ID & Gene ID & Long Name & & AY646356 & $\underline{P L C Z 1}$ & Bos taurus & phospholipase C, zeta 1 \\
\hline 2 & AY646356 & PLCZ1 & phospholipas & se C, ze & AB099079 & LOC782924 & Bos taurus & similar to elongation factor 1 alpha \\
\hline 3 & BC108207 & PRM1 & protamine 1 & & BC108207 & $\underline{\text { PRM1 }}$ & Bos taurus & protamine 1 \\
\hline 4 & BC102216 & PSMA1 & proteasome ( & (proson & $\mathrm{BC} 102713$ & GTSF1 & Bos taurus & gametocyte specific factor 1 \\
\hline 5 & & & & $9+$ & BC102216 & PSMA1 & Bos taurus & proteasome (prosome, macropain) subunit, alpha type, 1 \\
\hline 6 & & & & & AB098752 & $\underline{L O C 782525}$ & Bos taurus & eukaryotic translation elongation factor 1 gamma \\
\hline 9 & & & & & BC109790 & $\underline{\mathrm{Hmgb} 4}$ & Bos taurus & high-mobility \\
\hline
\end{tabular}

- Select all cells, then copy and "Paste Special" into same cells after clicking

"Values" on the pop-up menu 


\begin{tabular}{|c|c|c|c|}
\hline Paste Special & & ? & 8 \\
\hline \multicolumn{4}{|l|}{ Paste } \\
\hline (9) All & \multicolumn{3}{|c|}{ All using Source theme } \\
\hline Q Formulas & \multicolumn{3}{|c|}{ All except borders } \\
\hline (-) Values & \multicolumn{3}{|c|}{ Column widths } \\
\hline (9) Formats & \multicolumn{3}{|c|}{ Formulas and number formats } \\
\hline Comments & \multicolumn{3}{|c|}{ Values and number formats } \\
\hline \multicolumn{4}{|l|}{ Validation } \\
\hline \multicolumn{4}{|l|}{ Operation } \\
\hline (- None & \multicolumn{3}{|l|}{ Multiply } \\
\hline (1) Add & \multicolumn{3}{|l|}{ Divide } \\
\hline \multicolumn{4}{|l|}{ Subtract } \\
\hline$\square$ Skip blanks & \multicolumn{3}{|l|}{$\square$ Transpose } \\
\hline Paste Link & OK & \multicolumn{2}{|c|}{ Cancel } \\
\hline
\end{tabular}

- Delete reference table, leaving just the annotated original file. 


\section{APPENDIX II: RAW APE FILES USED FOR CHAPTER 2}

All primer sets here are labeled with the names used on the tubes as used in the laboratory. Primer titles were changed to a linear organization for chapter 2 to assist with cohesion of the work. No primer sequences were changed during this process. Below, the full genes with primer locations and sequencing locations are shown. The top bar on each represents the total length of the reference accession number.

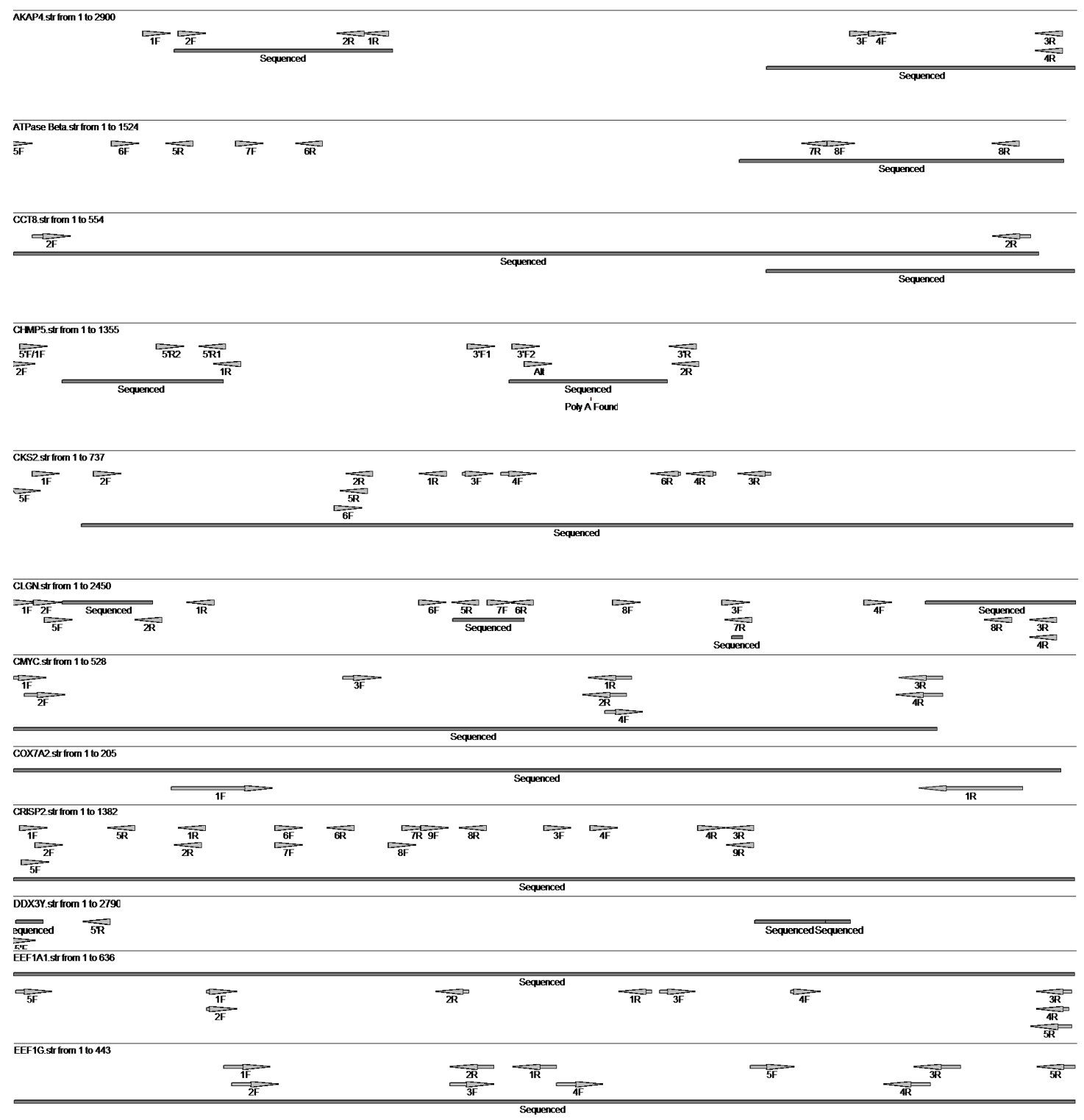




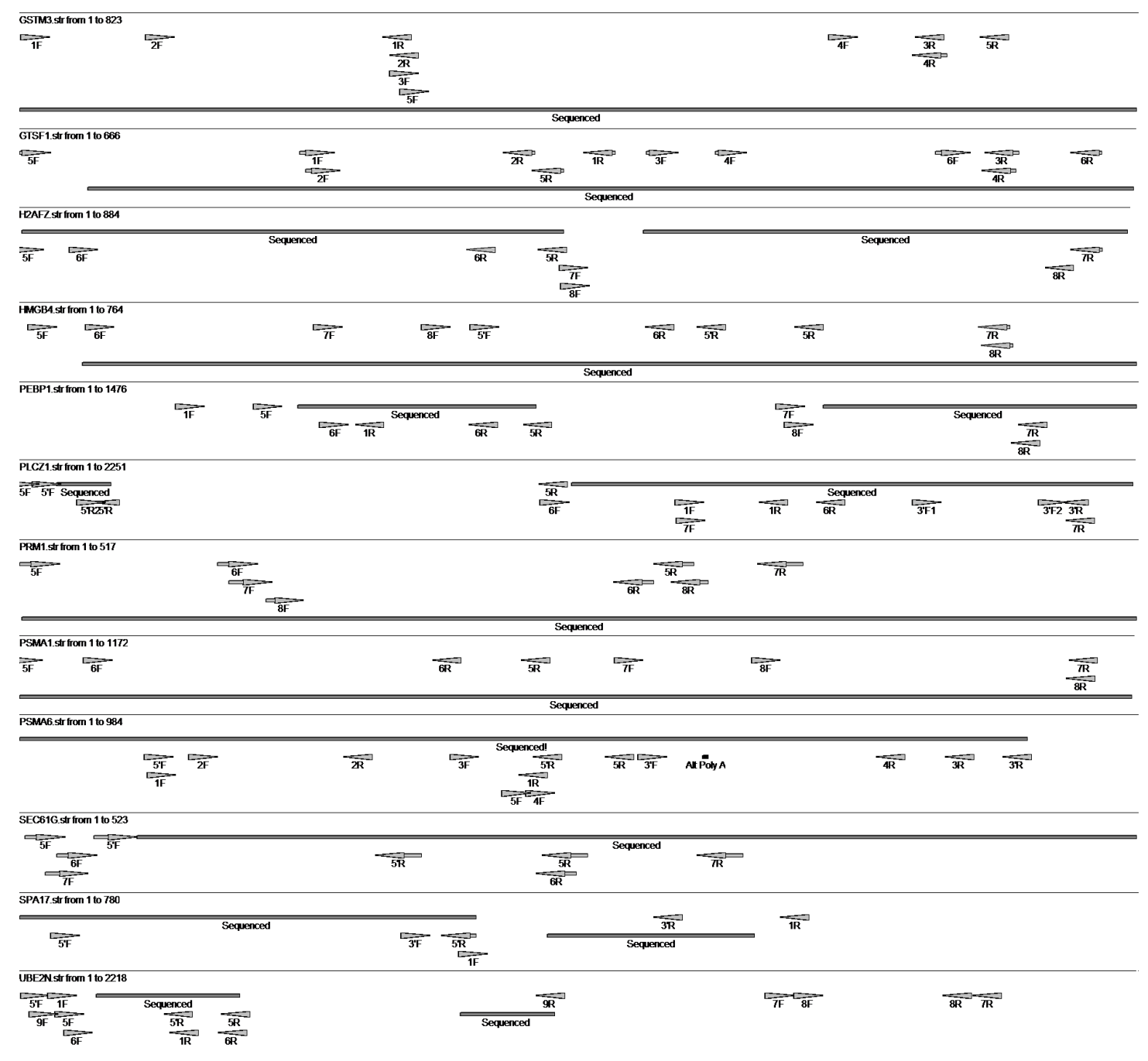

